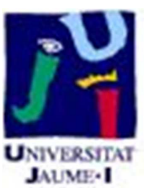

Título artículo / Títol article: Synthesis and Biological Evaluation of aTubulin-Binding Pironetin Analogues with Enhanced Lipophilicity

Autores / Autors

Miguel Carda, Juan Murga, Eva Falomir, Santiago Díaz Oltra, Jorge García Pla, Julián Paños, Chiara Trigili, J. Fernando Díaz, Isabel Barasoain, Alberto Marco

Revista:

European Journal of Organic Chemistry

Versión / Versió:

Postprint del autor

Cita bibliográfica / Cita

CARDA, Miguel; MURGA, Juan ; FALOMIR, bibliogràfica (ISO 690): Eva; DÍAZ OLTRA, Santiago; GARCÍA PLA, Jorge; PAÑOS, Julián ; TRIGILI, Chiara; DÍAZ, J. Fernando; BARASOAIN, Isabel; MARCO, Alberto. Synthesis and biological evaluation of $\alpha-$ tubulin-binding pironetin analogues with enhanced lipophilicity. European Journal of Organic Chemistry, 2013, vol. 2013, no 6, p. 1116-1123.

url Repositori UJI: 


\title{
Synthesis and biological evaluation of $\alpha$-tubulin-binding pironetin analogues with enhanced lipophilicity
}

\author{
Miguel Carda, ${ }^{[a]}$ Juan Murga, ${ }^{[a]}$ Eva Falomir, ${ }^{[a]}$ Santiago Díaz-Oltra, ${ }^{[a]}$ Jorge García-Pla, ${ }^{\text {[a] }}$ \\ Julián Paños, ${ }^{[a]}$ Chiara Trigili, ${ }^{[b]}$ J. Fernando Díaz, ${ }^{* b]}$ Isabel Barasoain, ${ }^{*[b]}$ and J. Alberto \\ $\operatorname{Marco}^{*[c]}$
}

Keywords: Tubulin / Microtubules / Microtubule-disrupting Compounds / Cytotoxicity / Lipophilic Pironetin Analogues

\begin{abstract}
The preparation of four new lipophilic analogues of the natural pyrone pironetin is described. The nine-carbon side chain of the latter has been replaced in one analogue by a 4-phenylbutyl chain and in the other three analogues by long aliphatic chains of thirteen and sixteen carbons, all of them bearing two stereogenic centers. Their cytotoxic activity and their interactions with tubulin have been investigated. It has been found that all four are cytotoxic towards two either sensitive or resistant tumoral cell lines with similar $\mathrm{IC}_{50}$ values in each case, thus indicating that, like the parent natural compound, they also display a covalent mechanism of action. However, one of them operates in all likelihood through a mechanism very similar to pironetin whereas the other three seem to be cytotoxic via a different mechanism.
\end{abstract}

[a] Departamento de Química Inorgánica y Orgánica, Univ. Jaume I, E12071 Castellón, Spain Fax No.: +34-964-728214

E-mail: mcarda@qio.uji.es

[b] Centro de Investigaciones Biológicas, Consejo Superior de Investigaciones Científicas, 28040 Madrid, Spain.

E-mail: barasoain@cib.csic.es, fer@cib.csic.es

[c] Departamento de Química Orgánica, Univ. de Valencia, c/D. Moliner, 50, E-46100 Burjassot, Spain.

Fax No.: +34-96-3544328.

E-mail: alberto.marco@uv.es

Supporting information for this article is available on the WWW under http://www.eurjoc.org/ or from the authors.

\section{Introduction}

Microtubules are dynamic polymers which play a central role in a number of cellular processes, most particularly cell division, as they are key constituents of the mitotic spindle. ${ }^{[1]}$ Their shape can be described as hollow tubes of about $25 \mathrm{~nm}$ external diameter constituted of a protein named tubulin. The functional form of this protein is a heterodimer formed in turn through non-covalent binding of two monomeric constituents. These are two structurally related polypeptides of about 450 amino acid residues which are called $\alpha$ - and $\beta$-tubulin. ${ }^{[2]}$ For cell division to occur in a normal way, microtubules must be in a constant state of formation and disruption, a process named microtubule dynamics in which GTP hydrolysis into GDP plays a key role. ${ }^{[3]}$

It is easy to understand that any molecule which exerts some type of action on microtubule dynamics will be able to influence the cell division process, not only of normal cells but also of tumoral ones. Since such an influence may be exerted by molecules that bind to any of the tubulin components, it is not surprising that tubulin-binding molecules (TBMs) constitute a very important class of anticancer agents. ${ }^{[4]}$ TBMs are able to interfere with microtubule assembly and functions, either by causing disruption of the microtubules or else through their stabilization. In both cases, this results in mitotic arrest of eukaryotic cells and subsequent cell death. Most of the hitherto described active drugs are natural products or derivatives thereof. ${ }^{[5]}$ Major drugs can already be found on the market and many other promising compounds are in clinical trials. ${ }^{[4,5]}$

TBMs may be divided in two broad categories, those that bind to $\alpha$-tubulin and those that bind to $\beta$-tubulin. The latter group is presently by far the most numerous and contains products which cause either disruption or stabilization of microtubules. Among the drugs that belong to this group, the well-known colchicine ${ }^{[6]}$ exerts its effects by causing disruption of microtubules. In contrast, another renowned representative of the same group, paclitaxel, was the first-described tubulin-interacting drug with the ability to stabilize microtubules. ${ }^{[7]}$ Despite the fact that they exert opposite effects on the mitotic spindle, both drugs are known to bind to $\beta$ tubulin, even though to different sites within that protein subunit. The mechanisms of action ${ }^{[8]}$ of many of these TBMs and the molecular aspects ${ }^{[9]}$ of their interactions with tubulin have been studied using a broad palette of methods. ${ }^{[10]}$

The number of products reported to bind to $\alpha$-tubulin is very small, the naturally occurring 5,6-dihydro- $\alpha$-pyrone pironetin (Fig. 1) being the first example, ${ }^{[11]}$ followed a short time later by the peptide-like hemiasterlin family. ${ }^{[12]}$ Pironetin proved a potent inhibitor of tubulin assembly and was found to arrest cell cycle progression in the G2/M phase. ${ }^{[13]}$ This feature has motivated a number of groups to undertake total syntheses of this natural compound. ${ }^{[14]}$ Some synthetic and biological studies on modified variants of pironetin have previously been published. ${ }^{[15]}$ 


\section{Insert Figure 1 here}

Some structure-activity (SAR) studies on pironetin have been reported. ${ }^{[13]}$ These studies have shown that the presence of the conjugated $\mathrm{C} 2-\mathrm{C} 3$ double bond and of the hydroxyl group at C-9, either free or methylated, are essential for the biological activity. The presence of a (7R)-hydroxyl group also seems to be very relevant. ${ }^{[13 \mathrm{c}]}$ The epoxidation of the $\mathrm{C} 12-\mathrm{C} 13$ double bond has been shown to cause a decrease in the activity ${ }^{[13 a, b]}$ but this may perhaps involve a deleterious effect of the oxirane ring, rather than a strict need of this $\mathrm{C}=\mathrm{C}$ bond. No data are available about the importance of the remaining structural features. ${ }^{[15]}$ It has been proposed that the Lys352 residue of the $\alpha$-tubulin chain adds in a Michael fashion to the conjugated double bond of pironetin, therefore forming a covalent bond with C-3 of the pyrone ring (Fig. 2). In addition, it has been suggested that the Asn258 residue of $\alpha$ tubulin holds the pironetin molecule through two hydrogen bonds to the pyrone carbonyl and the methoxyl oxygen atoms. ${ }^{[13]}$

\section{Insert Figure 2 here}

The appearance of resistances to existing drugs has led to a continuous need of developing new bioactive compounds that overcome such problems. Even though first observed in the case of antibiotics, resistances have also been reported to $\mathrm{TBM}^{[4 \mathrm{c}, \mathrm{e}, \mathrm{h}, 16]}$ The investigation of new members of this compound class therefore constitutes an important goal in chemistry and pharmacology. As a member of the up to now small group of products that bind to $\alpha$-tubulin, pironetin constitutes a pharmacologically interesting target. Thus, the purpose of our present research is the preparation of pironetin analogues that retain a substantial proportion of the biological activity of the natural metabolite while displaying a more simplified structure. Indeed, pironetin is not an extremely complex molecule but, with six $s p^{3}$ stereocenters, a total synthesis will be anyway lengthy enough as to make not very practical a preparation at large scale. Our investigation aims at establishing which elements of the pironetin molecule are essential for its activity and, desirably, at achieving an improvement of the latter.

In order to develop SAR studies based upon the pironetin framework, we started considering a simplified model structure where all elements that have not yet proven to be essential were removed. The elements that were maintained are the conjugated pyrone ring and the side chain with the methoxy group at C-9. The hydroxyl group at C-7 was removed in some substrates and retained in others, in order to see its influence on the activity. All alkyl pendants (methyls at C-8 and C-10, ethyl at C-4) and the isolated $\mathrm{C} 12-\mathrm{C} 13$ double bond were removed. The configurations of the three remaining stereocenters were varied in a systematic way. Accordingly, the selected target structures are schematically shown in Figure 3. All four possible stereoisomers with general constitution $\mathbf{1}$, where no hydroxyl group at $\mathrm{C}-7$ is present, were prepared. Furthermore, all eight stereoisomers with constitution 2, with a hydroxyl group at C-7, were synthesized. ${ }^{[17]}$

\section{Insert Figure 3 here}

The cytotoxic activity of these analogues and their interactions with tubulin were subsequently investigated. For the measurement of the cytotoxic activity, the ovarian carcinoma cells sensitive (A2780) and resistant (A2780AD) to chemotherapy by Pglycoprotein overexpression were used. ${ }^{[17]}$ It was found on one hand that the analogues were cytotoxic in the low micromolar range, thus about three orders of magnitude less active than the parent molecule. ${ }^{[17]}$ On the other hand, they behaved in the same way as pironetin in that they killed both resistant and non resistant cells with a similar $\mathrm{IC}_{50}$, as expected for compounds with a covalent mechanism of action. ${ }^{[13]}$ The general conclusion was that the synthetic pironetin analogues share the mechanism of action of the natural compound and compete for the same binding site to $\alpha$ tubulin, leading to disruption of the microtubule network. It is worth mentioning that variations in the configurations of the three stereocenters (C-5, C-7, C-9) did not translate into significant differences in the biological activity. ${ }^{[17]}$

In continuation of our efforts in this line of research, we have now investigated the influence of the nature of the lipophilic side chain attached to the dihydropyrone ring. Indeed, we intend to prepare tubulin-active molecules with a hybrid structure and the ability to bind to two different points in the tubulin network. Since one half of these hybrid molecules will be pironetin-like, we wish to acquire knowledge about the nature and size of the required spacer fragment. Accordingly, the four pironetin analogues 3-6 were prepared (Fig. 4). As regards the stereocenters, and in view of the aforementioned fact that their configurations do not seem to play a significant role in the biological activity, compounds 3-6 were prepared with the same configuration as natural pironetin at C-5, C-7 and C-9. The difference with the previously reported analogues 1-2 resides in the lipophilic end of the side chain, which is much longer in $\mathbf{3}$ and $\mathbf{4}$. Compound $\mathbf{5}$ is an $O$-methylated analogue of $\mathbf{4}$ whereas compound $\mathbf{6}$ contains a phenyl ring instead of the aliphatic chain.

Insert Figure 4 here

\section{Results and Discussion}

\section{Chemical results}

Dihydropyrones 3-6 were prepared using the methodology employed in the case of compounds of general structure $2 .{ }^{[1]}$ Scheme 1 depicts the details of the synthetic sequence for the case of pyrone 3 , where $n$-decanal was the starting material.

\section{Insert Scheme 1 here}

Brown's asymmetric allylation of $n$-decanal using a chiral allylborane afforded homoallyl alcohol 7 . The required borane was prepared through reaction of allylmagnesium bromide with the commercially available (-)-diisopinocampheylboron chloride, $(-)$ $\mathrm{Ipc}_{2} \mathrm{BCl}^{[18]}$ Methylation of the free hydroxyl group of compound 7 yielded methyl ether 8. Ozonolytic cleavage of the olefinic bond in 8 gave the intermediate aldehyde $\mathbf{9}$, which was not isolated but directly subjected to asymmetric allylation, this time using the chiral allylborane formed from allylmagnesium bromide and $(+)-$ $\mathrm{Ipc}_{2} \mathrm{BCl}$. This gave rise to homoallyl alcohol $\mathbf{1 0}$ as an inseparable mixture of diastereoisomers in a 88:12 ratio. Silylation of this mixture gave 11, which was subjected to ozonolytic cleavage of the $\mathrm{C}=\mathrm{C}$ bond. Without purification, the intermediate aldehyde 12 was submitted to asymmetric allylation with the chiral allylborane generated from (-)- $\mathrm{Ipc}_{2} \mathrm{BCl}$ and allylmagnesium bromide. This provided homoallylic alcohol $\mathbf{1 3}$ as a single diastereoisomer, the minor stereoisomer being removed during the chromatographic separation. Reaction of $\mathbf{1 3}$ with acryloyl chloride at low temperature gave acrylate 14, which was then subjected to ringclosing metathesis ${ }^{[19]}$ in the presence of Grubbs first-generation catalyst Ru-I. This afforded the corresponding dihydropyrone which, after acid-catalyzed desylilation, yielded pironetin analogue 3.

An analogous reaction sequence starting from $n$-tridecanal served to prepare dihydropyrones $\mathbf{4}$ and $\mathbf{5}$, whereas benzaldehyde was used for the synthesis of $\mathbf{6}$. The complete details of these syntheses are given in the Supporting Information. 


\section{Biological results}

Cellular effects of the compounds. We have determined the $\mathrm{IC}_{50}$ values for analogues 3-6 and compared them with that of pironetin on A2780 and A2780AD human ovary carcinomas (Table 1). Pironetin proved active in both the parental and the resistant cell lines, as expected for a compound with a covalent mechanism of action. ${ }^{[20]}$ While about three orders of magnitude less active than pironetin, analogues 3-6 have also been found cytotoxic towards A2780 and A2780AD cells and are able to kill both resistant and non resistant cells with similar $\mathrm{IC}_{50}$ values. As commented above, this is what should be expected for compounds with a covalent mechanism of action.

In order to study the effect of compounds 3-6 on the microtubule cytoskeleton, we incubated cells in the presence of these ligands for 24 hours (Fig. 5). Pironetin at $50 \mathrm{nM}$ concentration completely depleted cytoplasmic microtubules (C,D and inset): cells are arrested in the prometaphase ${ }^{[13 a, b]}$ and type III mitotic spindles are observed, ${ }^{[21]}$ with the chromosomes being arranged in a ball of condensed DNA enclosing one or more star-shaped aggregates of microtubules.

With $100 \mu \mathrm{M}$ 3, $25 \mu \mathrm{M} 4$ and $15 \mu \mathrm{M}$ 5, disorganization and some depolymerization of the microtubule cytoskeleton are observed: the cells get rounded and detach from the plastic substrate were they are growing, with shrinking of the cell nucleus occurring in some cases (Fig. 5, E-J). No mitotic cells are observed in these cell preparations. However, ligand 6 at $200 \mu \mathrm{M}$ is found to cause microtubule depolymerization and cell arrest at the prometaphase, as in the case of pironetin (see Fig. 5, K,L and inset)

We next studied whether ligands 3-6 were capable of blocking cells in the G2/M phase of the cell cycle of A549, as other microtubule modulating agents do. We incubated these cells for 20 hours in the presence of the different ligands (3-6) or the drug vehicle (Fig. 6). Pironetin at $50 \mathrm{nM}$ concentration almost completely arrested cells in the $\mathrm{G} 2 / \mathrm{M}$ phase and, interestingly, so did $200 \mu \mathrm{M}$ 6. In contrast, ligands $3(100 \mu \mathrm{M}), 4(50 \mu \mathrm{M})$, and 5 $(10 \mu \mathrm{M})$ only caused a decrease in the number of G2/M cells with appearance of subG1 cells, presumably dying cells. These results indicate that, although markedly less active, compound $\mathbf{6}$ is the only ligand that behaves like pironetin. In addition, the results further indicate that compounds 3-5, while being active against the tubulin cytoskeleton, may exert their cytotoxicity through an alternative pathway.

Tubulin assembly. The critical concentration of tubulin required for assembly was determined in $\mathrm{GAB}$ in the presence of a large excess $(100 \mu \mathrm{M})$ of compounds 3-6 (Table 2). As shown in the Table, the concentration of tubulin required to produce assembly (critical concentration ${ }^{[22]}$ ) oscillate between $3.3 \mu \mathrm{M}$ in the absence of ligands and $4.9 \mu \mathrm{M}$ in the presence of 5 , the most active of these compounds as regards this property. The observed increase of the critical concentration required indicates that, as expected for a pironetin analogue, compounds 3-6 are also able to inhibit the assembly of tubulin.

\section{Summary}

Four new pironetin derivatives 3-6 with an extended lypophilic side chain were synthesized with the aim at exploring the influence of the side chain in their biological activity. All the compounds are cytotoxic in the micromolar range against both non-resistant and resistant p-glycoprotein overexpressing, multidrug ovarian carcinoma cell lines, similar $\mathrm{IC}_{50}$ values being found in both cell lines. However, although all the aforementioned compounds are able to inhibit microtubule assembly, both in vitro and in cell cultures, thus sharing the general mechanism of action of tubulin assembly inhibition, compounds 3-5 containing a long aliphatic side chain differ from pironetin and compound $\mathbf{6}$ in that they do not accumulate cells in the $\mathrm{G} 2 / \mathrm{M}$ phase of the cell cycle. This indicates that, in contrast to pironetin and 6, compounds 3-5 trigger an alternative mechanism for cytotoxicity which leads to cell death.

\section{Experimental Section}

\section{Chemical procedures}

General experimental procedures: ${ }^{1} \mathrm{H} /{ }^{13} \mathrm{C}$ NMR spectra were measured at $500 / 125 \mathrm{MHz}$ in $\mathrm{CDCl}_{3}$ solution at $25^{\circ} \mathrm{C}$. The signals of the deuterated solvent $\left(\mathrm{CDCl}_{3}\right)$ were taken as the reference (the singlet at $\delta 7.25$ for ${ }^{1} \mathrm{H}$ $\mathrm{NMR}$ and the triplet centered at $77.00 \mathrm{ppm}$ for ${ }^{13} \mathrm{C}$ NMR data). Carbon atom types $\left(\mathrm{C}, \mathrm{CH}, \mathrm{CH}_{2}, \mathrm{CH}_{3}\right)$ were determined with the DEPT pulse sequence. High resolution mass spectra were run by the electrospray mode (ESMS). IR data are given only for compounds with significant functions $(\mathrm{OH}, \mathrm{C}=\mathrm{O})$ and were recorded as oily films on $\mathrm{NaCl}$ plates (oils) or as $\mathrm{KBr}$ pellets (solids). Optical rotations were measured at $25^{\circ} \mathrm{C}$. Reactions which required an inert atmosphere were carried out under $\mathrm{N}_{2}$ with flame-dried glassware. $\mathrm{Et}_{2} \mathrm{O}$ and THF were freshly distilled from sodium/benzophenone ketyl and transferred via syringe. Dichloromethane was freshly distilled from $\mathrm{CaH}_{2}$. Tertiary amines were freshly distilled from $\mathrm{KOH}$. Toluene was freshly distilled from sodium wire. Commercially available reagents were used as received. Unless detailed otherwise, "work-up" means pouring the reaction mixture into brine, followed by extraction with the solvent indicated in parenthesis. If the reaction medium was acidic, an additional washing with $5 \%$ aq $\mathrm{NaHCO}_{3}$ was performed. If the reaction medium was basic, an additional washing with aq $\mathrm{NH}_{4} \mathrm{Cl}$ was performed. New washing with brine, drying over anhydrous $\mathrm{Na}_{2} \mathrm{SO}_{4}$ and elimination of the solvent under reduced pressure were followed by chromatography on a silica gel column (60-200 $\mu \mathrm{m})$ and elution with the indicated solvent mixture. Where solutions were filtered through a Celite pad, the pad was additionally washed with the same solvent used, and the washings incorporated to the main organic layer.

(R)-Tridec-1-en-4-ol (7). Allylmagnesium bromide (commercial 1M solution in $\mathrm{Et}_{2} \mathrm{O}, 15 \mathrm{~mL}, 15 \mathrm{mmol}$ ) was added dropwise under $\mathrm{N}_{2}$ via syringe to a cooled solution of $(+)-\mathrm{Ipc}_{2} \mathrm{BCl}(5.77 \mathrm{~g}, \sim 18 \mathrm{mmol})$ in $\operatorname{dry} \mathrm{Et}_{2} \mathrm{O}$ $(75 \mathrm{~mL})$ (dry ice-acetone bath). After finishing the addition, the dry iceacetone bath was replaced by an ice bath, and the mixture was stirred for 1 $\mathrm{h}$. The solution was allowed to stand, whereby precipitation of magnesium chloride took place. The supernatant solution was carefully transferred to another flask via canula. After cooling this flask at $-90{ }^{\circ} \mathrm{C}$, a solution of $n$ decanal $(2.25 \mathrm{~mL}, 1.87 \mathrm{~g}, 12 \mathrm{mmol})$ in dry $\mathrm{Et}_{2} \mathrm{O}(35 \mathrm{~mL})$ was added dropwise via syringe. The resulting solution was further stirred at $-90^{\circ} \mathrm{C}$ for $2 \mathrm{~h}$. The reaction mixture was quenched through addition of phosphate pH 7 buffer solution (15 mL), MeOH (15 mL) and 30\% $\mathrm{H}_{2} \mathrm{O}_{2}(7 \mathrm{~mL})$. After stirring for $30 \mathrm{~min}$., the mixture was poured onto satd. aq $\mathrm{NaHCO}_{3}$ and worked up (extraction with $\mathrm{Et}_{2} \mathrm{O}$ ). The residue was subjected to a careful column chromatography on silica gel (hexanes, then hexanes-EtOAc, 9:1) to afford 7 (2.26 mg, 95\%): oil; $[\alpha]_{\mathrm{D}}+3.3\left(\mathrm{c} 1.1 ; \mathrm{CHCl}_{3}\right)$. Physical and spectral data as reported. ${ }^{[23]}$ The enantiomeric ratio was found to be $96: 4$ by means of chiral HPLC using a Kromasil 5-AmyCoat column (4.6 x $20 \mathrm{~mm})$. Elution was performed with a hexane/isopropanol 99:1 mixture, and a flux of $0.4 \mathrm{~mL} / \mathrm{min}$. Elution times of both enantiomers: $21.21(\mathrm{~S})$ and $22.87 \mathrm{~min}$ $(R)$.

(R)-4-Methoxytridec-1-ene (8). Sodium hydride (60\% slurry in mineral oil, amount equivalent to $20 \mathrm{mmol}$ ) was washed two times under $\mathrm{N}_{2}$ with dry hexane and once with dry THF. Then, THF $(75 \mathrm{~mL})$ was added and the 
suspension was cooled in an ice bath. Alcohol 7 (1.98 g, $10 \mathrm{mmol})$ was then dissolved in dry THF $(25 \mathrm{~mL})$ and added dropwise to the sodium hydride suspension. The mixture was then allowed to reach room temperature. Subsequently, methyl iodide $(1.87 \mathrm{~mL}$, ca. $30 \mathrm{mmol})$ was added in one portion and the mixture was stirred overnight at room temp. Work-up $\left(\mathrm{Et}_{2} \mathrm{O}\right)$ was followed by column chromatography on silica gel (hexanesEtOAc, 19:1) to afford 8 (1.95 g, 92\%): oil; $[\alpha]_{\mathrm{D}}+2.9\left(\right.$ c $\left.0.1 ; \mathrm{CHCl}_{3}\right)$; IR and ${ }^{1} \mathrm{H}$ NMR data as reported ${ }^{[24]} ;{ }^{13} \mathrm{C}$ NMR $(125 \mathrm{MHz}) \delta 135.1,80.6(\mathrm{CH})$, 116.7, 37.8, 33.4, 31.9, 29.8, 29.7, 29.6, 29.4, 25.3, $22.7\left(\mathrm{CH}_{2}\right), 56.5,14.1$ $\left(\mathrm{CH}_{3}\right)$.

(4R,6R)-6-Methoxypentadec-1-en-4-ol (10). Olefin 8 (1.275 g, ca. 6 mmol) was dissolved in $\mathrm{CH}_{2} \mathrm{Cl}_{2}(100 \mathrm{~mL})$ and cooled to $-78^{\circ} \mathrm{C}$. A stream of ozone-containing air was then bubbled through the solution until complete consumption of the starting material (TLC monitoring). Ozone residues were then eliminated by bubbling a stream of $\mathrm{N}_{2}$, and the mixture was allowed to reach room temperature, treated with $\mathrm{PPh}_{3}(3.15 \mathrm{~g}, \sim 12$ $\mathrm{mmol}$ ) and allowed to stir for 2 hours. After solvent removal under reduced pressure, the crude residue was stirred for $10 \mathrm{~min}$. under cold pentane (40 $\mathrm{mL}$ ) and filtered. The solution was then concentrated under reduced pressure and the crude residue containing $\mathbf{9}$ was used directly in the next step.

Allylmagnesium bromide (commercial $1 \mathrm{M}$ solution in $\mathrm{Et}_{2} \mathrm{O}, 8 \mathrm{~mL}, 8 \mathrm{mmol}$ ) was added dropwise under $\mathrm{N}_{2}$ via syringe to a cooled solution of (+)$\mathrm{Ipc}_{2} \mathrm{BCl}(3.2 \mathrm{~g}, \sim 10 \mathrm{mmol})$ in dry $\mathrm{Et}_{2} \mathrm{O}(50 \mathrm{~mL})$ (dry ice-acetone bath). After finishing the addition, the dry ice-acetone bath was replaced by an ice bath, and the mixture was stirred for $1 \mathrm{~h}$. The solution was allowed to stand, whereby precipitation of magnesium chloride took place. The supernatant solution was carefully transferred to another flask via canula. After cooling this flask at $-90^{\circ} \mathrm{C}$, a solution of the crude aldehyde 9 from above in dry $\mathrm{Et}_{2} \mathrm{O}(15 \mathrm{~mL})$ was added dropwise via syringe. The resulting solution was further stirred at $-90^{\circ} \mathrm{C}$ for $2 \mathrm{~h}$. The reaction mixture was quenched through addition of phosphate $\mathrm{pH} 7$ buffer solution $(40 \mathrm{~mL}), \mathrm{MeOH}(40$ $\mathrm{mL}$ ) and $30 \% \mathrm{H}_{2} \mathrm{O}_{2}(20 \mathrm{~mL})$. After stirring for $30 \mathrm{~min}$., the mixture was poured onto satd. aq $\mathrm{NaHCO}_{3}$ and worked up (extraction with $\mathrm{Et}_{2} \mathrm{O}$ ). The residue was subjected to a careful column chromatography on silica gel (hexanes, then hexanes-EtOAc, 19:1) to afford $\mathbf{1 0}(1.077 \mathrm{~g}, 70 \%$ overall from 8 ) as an 88:12 mixture of diastereoisomers which were very difficult to separate and was used as such in the next step. For analytical purposes, an aliquot could be concentrated to about $95 \%$ purity by means of careful column chromatography: oil; $[\alpha]_{\mathrm{D}}-22.8\left(\right.$ ( $\left.0.8 ; \mathrm{CHCl}_{3}\right) ;{ }^{1} \mathrm{H}$ NMR (500 MHz) $\delta 5.85(1 \mathrm{H}, \mathrm{ddt}, J=17,10,7 \mathrm{~Hz}), 5.15-5.05(2 \mathrm{H}, \mathrm{br} \mathrm{m}), 3.95(1 \mathrm{H}$, m), $3.48(1 \mathrm{H}, \mathrm{m}), 3.37(3 \mathrm{H}, \mathrm{s}), 2.90(1 \mathrm{H}, \mathrm{br} \mathrm{s}, \mathrm{OH}), 2.25(2 \mathrm{H}, \mathrm{m}), 1.70-1.40$ (4H, br m), 1.35-1.25 (14H, br m), $0.89(3 \mathrm{H}, \mathrm{t}, J=7 \mathrm{~Hz}) ;{ }^{13} \mathrm{C}$ NMR $(125$ MHz) $\delta 135.0,79.3,68.0(\mathrm{CH}), 117.5,42.3,39.0,33.1,31.9,29.8,29.6$, 29.5, 29.3, 25.4, $22.7\left(\mathrm{CH}_{2}\right), 56.7,14.1\left(\mathrm{CH}_{3}\right)$. HR ESMS $\mathrm{m} / \mathrm{z}$ (\% rel. int.) 279.2302 (M+Na $\left.{ }^{+}\right)$. Calcd. for $\mathrm{C}_{16} \mathrm{H}_{32} \mathrm{NaO}_{2}, 279.2300$.

(4R,6R)-4-(Tert-butyldimethylsilyloxy)-6-methoxypentadec-1-ene (11). Alcohol 10 (1.025 g, 4 mmol) was dissolved under $\mathrm{N}_{2}$ in dry $\mathrm{CH}_{2} \mathrm{Cl}_{2}(20$ $\mathrm{mL})$ and treated sequentially with 2,6-lutidine $(700 \mu \mathrm{L}, 6 \mathrm{mmol})$ and TBSOTf $(1.15 \mathrm{~mL}, 5 \mathrm{mmol})$. The reaction mixture was then stirred for $1 \mathrm{~h}$ at room temp. and worked up (extraction with $\mathrm{CH}_{2} \mathrm{Cl}_{2}$ ). Column chromatography on silica gel (hexanes-EtOAc, 19:1) afforded 11 (1.33 g, $90 \%$ ) as an 88:12 mixture of diastereoisomers which were very difficult to separate and was used as such in the next step. For analytical purposes, an aliquot could be concentrated to about $95 \%$ purity by means of careful column chromatography: oil; $[\alpha]_{\mathrm{D}}-8.2\left(\mathrm{c} 0.1 ; \mathrm{CHCl}_{3}\right) ;{ }^{1} \mathrm{H} \mathrm{NMR}(500$ MHz) $\delta 5.82(1 \mathrm{H}, \mathrm{ddt}, J=17,10,7 \mathrm{~Hz}), 5.10-5.00(2 \mathrm{H}, \mathrm{br} \mathrm{m}), 3.93(1 \mathrm{H}$, $\mathrm{m}), 3.34(1 \mathrm{H}, \mathrm{m}), 3.30(3 \mathrm{H}, \mathrm{s}), 2.24(2 \mathrm{H}, \mathrm{m}), 1.60-1.40(4 \mathrm{H}, \mathrm{br} \mathrm{m}), 1.35-$ $1.25(14 \mathrm{H}, \mathrm{br} \mathrm{m}), 0.90(12 \mathrm{H}$, strong singlet of $9 \mathrm{H}$ overlapping a methyl triplet at $0.89 \mathrm{ppm}), 0.08(6 \mathrm{H}, \mathrm{s}),{ }^{13} \mathrm{C} \mathrm{NMR}(125 \mathrm{MHz}) \delta 18.1(\mathrm{C}), 134.9$, 77.1, $68.6(\mathrm{CH}), 117.0,42.8,41.7,33.0,31.9,29.9,29.7,29.6,29.3,24.8$,
$22.7\left(\mathrm{CH}_{2}\right), 55.7,26.0$ (x 3), 14.1, -4.1, $-4.7\left(\mathrm{CH}_{3}\right)$. HR ESMS $\mathrm{m} / \mathrm{z}$ (\% rel. int.) $393.3162\left(\mathrm{M}+\mathrm{Na}^{+}\right)$. Calcd. for $\mathrm{C}_{22} \mathrm{H}_{46} \mathrm{NaO}_{2} \mathrm{Si}, 393.3165$.

(4S,6R,8R)-6-(Tert-butyldimethylsilyloxy)-8-methoxyheptadec-1-en-4-ol (13). Prepared in two steps from 11 (via the non isolated aldehyde 12) in $47 \%$ overall yield according to the same experimental conditions as in the 8 $\rightarrow \mathbf{1 0}$ step. Careful chromatography on silica gel (hexane- $\mathrm{Et}_{2} \mathrm{O}, 9: 1$, then $8: 2)$ permitted the isolation of $\mathbf{1 3}$ as a diastereomerically pure compound (by NMR): oil; $[\alpha]_{\mathrm{D}}-4.1$ (c $0.1 ; \mathrm{CHCl}_{3}$ ); IR $v_{\max } 3400$ (br, OH) $\mathrm{cm}^{-1} ;{ }^{1} \mathrm{H}$ NMR $(500 \mathrm{MHz}) \delta 5.82(1 \mathrm{H}, \mathrm{ddt}, J=17,10,7 \mathrm{~Hz}), 5.15-5.05(2 \mathrm{H}, \mathrm{br} \mathrm{m})$, $4.18(1 \mathrm{H}, \mathrm{m}), 4.05(1 \mathrm{H}, \mathrm{m}), 3.50(1 \mathrm{H}, \mathrm{br} \mathrm{s}, \mathrm{OH}), 3.29(3 \mathrm{H}, \mathrm{s}), 3.26(1 \mathrm{H}, \mathrm{m})$, 2.30-2.10 (2H, br m), 1.70-1.50 (4H, br m), 1.35-1.25 (16H, br m), 0.90 $(12 \mathrm{H}$, strong singlet of $9 \mathrm{H}$ overlapping a methyl triplet at $0.89 \mathrm{ppm}), 0.12$ $(3 \mathrm{H}, \mathrm{s}), 0.10(3 \mathrm{H}, \mathrm{s}) ;{ }^{13} \mathrm{C} \mathrm{NMR}(125 \mathrm{MHz}) \delta 17.9(\mathrm{C}), 135.0,77.3,69.3$, 68.1 (CH), 117.0, 42.4, 42.1, 41.0, 32.8, 31.9, 29.9, 29.7, 29.6, 29.3, 24.7, $22.7\left(\mathrm{CH}_{2}\right), 55.6,25.9$ (x 3), 14.1, $-4.4,-4.9\left(\mathrm{CH}_{3}\right)$.

(4S,6S,8R)-6-(Tert-butyldimethylsilyloxy)-8-methoxyheptadec-1-en-4-yl acrylate (14). Compound $13(415 \mathrm{mg}$, ca. $1 \mathrm{mmol})$ was dissolved under $\mathrm{N}_{2}$ in dry $\mathrm{CH}_{2} \mathrm{Cl}_{2}(30 \mathrm{~mL})$, cooled to $-78^{\circ} \mathrm{C}$ and treated sequentially with $\mathrm{N}, \mathrm{N}$ diisopropyl ethylamine $(2.1 \mathrm{~mL}, 12 \mathrm{mmol})$ and acryloyl chloride $(815 \mu \mathrm{L}$, ca. $10 \mathrm{mmol}$ ). The reaction mixture was stirred at $-78^{\circ} \mathrm{C}$ until consumption of the starting material (about $45 \mathrm{~min}$., TLC monitoring). Work-up (extraction with $\mathrm{CH}_{2} \mathrm{Cl}_{2}$ ) and column chromatography on silica gel (hexane-Et $\left.{ }_{2} \mathrm{O}, 9: 1\right)$ provided 14 (361 mg, 77\%): oil; $[\alpha]_{\mathrm{D}}+2.2$ (c 0.5; $\left.\mathrm{CHCl}_{3}\right)$; IR $v_{\max } 1727(\mathrm{C}=\mathrm{O}) \mathrm{cm}^{-1} ;{ }^{1} \mathrm{H}$ NMR $(500 \mathrm{MHz}) \delta 6.38(1 \mathrm{H}, \mathrm{dd}, J=$ $17.3,1.5 \mathrm{~Hz}), 6.10(1 \mathrm{H}, \mathrm{dd}, J=17.3,10.5 \mathrm{~Hz}), 5.80(1 \mathrm{H}, \mathrm{dd}, J=10.5,1.5$ $\mathrm{Hz}), 5.78(1 \mathrm{H}, \mathrm{ddt}, J=17,10.2,7 \mathrm{~Hz}), 5.10-5.00(3 \mathrm{H}, \mathrm{br} \mathrm{m}), 3.86(1 \mathrm{H}, \mathrm{m})$, $3.29(3 \mathrm{H}, \mathrm{s}), 3.28(1 \mathrm{H}, \mathrm{m}), 2.40(2 \mathrm{H}, \mathrm{m}), 1.85-1.40(6 \mathrm{H}, \mathrm{br} \mathrm{m}), 1.35-1.25$ $(14 \mathrm{H}$, br m), $0.89(12 \mathrm{H}$, strong singlet of $9 \mathrm{H}$ overlapping a methyl triplet at $0.89 \mathrm{ppm}), 0.05$ (3H, s), 0.04 (3H, s); ${ }^{13} \mathrm{C}$ NMR (125 MHz) $\delta 165.7,18.0$ (C), 133.4, 129.0, 77.5, 71.2, $67.0(\mathrm{CH}), 130.2,118.0,42.7,42.0,39.0,33.2$, 31.9, 29.9, 29.7, 29.6, 29.3, 24.7, $22.7\left(\mathrm{CH}_{2}\right), 55.8,26.0$ (x 3), 14.1, -4.3, $-4.4\left(\mathrm{CH}_{3}\right)$; HR ESMS $\mathrm{m} / \mathrm{z}$ (\% rel. int.) $491.3529\left(\mathrm{M}+\mathrm{Na}^{+}\right)$. Calcd. for $\mathrm{C}_{27} \mathrm{H}_{52} \mathrm{NaO}_{4} \mathrm{Si}, 491.3533$.

(6S)-6-[(2S,4R)-2-(Tert-butyldimethylsilyloxy)-4-methoxytridecyl]-5,6dihydro-2H-pyran-2-one (15). Diolefin 14 (234 mg, ca. $0.5 \mathrm{mmol}$ ) was dissolved under $\mathrm{N}_{2}$ in dry, degassed $\mathrm{CH}_{2} \mathrm{Cl}_{2}(50 \mathrm{~mL})$ and treated with Grubbs catalyst $\mathrm{PhCH}=\mathrm{RuCl}_{2}\left(\mathrm{PCy}_{3}\right)_{2}(41 \mathrm{mg}$, ca. $0.05 \mathrm{mmol})$. The mixture was heated at reflux until consumption of the starting material (ca. $4 \mathrm{~h}$, TLC monitoring). Solvent removal under reduced pressure and column chromatography on silica gel (hexane-EtOAc, 19:1) yielded pyranone 15 (187 mg, 85\%): ): oil; $[\alpha]_{\mathrm{D}}-6.5$ (c 0.2, $\left.\mathrm{CHCl}_{3}\right)$; IR $v_{\max } 1732(\mathrm{C}=\mathrm{O}) \mathrm{cm}^{-1}$; ${ }^{1} \mathrm{H}$ NMR $(500 \mathrm{MHz}) \delta 6.86(1 \mathrm{H}, \mathrm{dt}, J=9.7,4 \mathrm{~Hz}), 6.00(1 \mathrm{H}, \mathrm{br} \mathrm{d}, J=9.7$ $\mathrm{Hz}), 4.58(1 \mathrm{H}, \mathrm{m}), 4.06(1 \mathrm{H}, \mathrm{m}), 3.28(3 \mathrm{H}, \mathrm{s}), 3.26(1 \mathrm{H}$, quint, $J \sim 6 \mathrm{~Hz})$, $2.30(2 \mathrm{H}, \mathrm{m}), 2.00(1 \mathrm{H}, \mathrm{m}), 1.65-1.55(3 \mathrm{H}, \mathrm{br} \mathrm{m}), 1.55-1.40(2 \mathrm{H}, \mathrm{br} \mathrm{m})$, $1.35-1.20(14 \mathrm{H}$, br m $), 0.87(12 \mathrm{H}$, strong singlet of $9 \mathrm{H}$ overlapping a methyl triplet at $0.89 \mathrm{ppm}), 0.07(3 \mathrm{H}, \mathrm{s}), 0.06(3 \mathrm{H}, \mathrm{s}) ;{ }^{13} \mathrm{C} \mathrm{NMR}(125 \mathrm{MHz})$ $\delta$ 164.2, $18.0(\mathrm{C}), 145.1,121.5,77.7,74.5,66.3(\mathrm{CH}), 43.3,43.1,33.2,31.9$, 29.9, 29.7, 29.6, 29.5, 29.3, 24.7, $22.6\left(\mathrm{CH}_{2}\right), 55.8,25.9$ (x 3), 14.1, -4.4, $-4.5\left(\mathrm{CH}_{3}\right)$; HR ESMS $\mathrm{m} / \mathrm{z}$ (\% rel. int.) $463.3218\left(\mathrm{M}+\mathrm{Na}^{+}\right)$. Calcd. for $\mathrm{C}_{25} \mathrm{H}_{48} \mathrm{NaO}_{4} \mathrm{Si}, 463.3219$.

(6S)-6-[(2S,4R)-2-Hydroxy-4-methoxytridecyl]-5,6-dihydro-2H-pyran2-one (3). Compound 15 (132 mg, $0.3 \mathrm{mmol}$ ) was dissolved in $\mathrm{MeOH}$ (15 $\mathrm{mL})$ and treated with PPTS $(15 \mathrm{mg}, 0.06 \mathrm{mmol})$ and water $(0.15 \mathrm{~mL})$. The mixture was then heated at reflux overnight, cooled and neutralized by addition of solid $\mathrm{NaHCO}_{3}$. After filtering, the solution was evaporated under reduced pressure, and the oily residue was subjected to column chromatography on silica gel (hexanes-EtOAc, 1:4). This provided 3 (88 mg, 90\%): oil; $[\alpha]_{\mathrm{D}}-16\left(\mathrm{c} 1, \mathrm{CHCl}_{3}\right)$; IR $v_{\max } 1712(\mathrm{C}=\mathrm{O}) \mathrm{cm}^{-1} ;{ }^{1} \mathrm{H} \mathrm{NMR}$ $(500 \mathrm{MHz}) \delta 6.86(1 \mathrm{H}, \mathrm{m}), 6.00(1 \mathrm{H}, \mathrm{d}, J=9.5 \mathrm{~Hz}), 4.72(1 \mathrm{H}, \mathrm{m}), 4.22(1 \mathrm{H}$, 
m), $3.45(1 \mathrm{H}, \mathrm{m}), 3.35(4 \mathrm{H}$, br s, $\mathrm{OMe}+\mathrm{OH}), 2.45-2.30(2 \mathrm{H}, \mathrm{br} \mathrm{m}), 1.90$ $1.40\left(6 \mathrm{H}\right.$, br m), $1.35-1.20\left(14 \mathrm{H}\right.$, br m), $0.87(3 \mathrm{H}, \mathrm{t}, J=6.8 \mathrm{~Hz}) ;{ }^{13} \mathrm{C} \mathrm{NMR}$ (125 MHz) $\delta 164.4(\mathrm{C}), 145.2,121.4,79.6,75.1,64.7(\mathrm{CH}), 42.9,39.4$, 32.8, 31.9, 30.0, 29.7, 29.6, 29.5, 29.3, 25.5, $22.6\left(\mathrm{CH}_{2}\right), 56.6,14.1\left(\mathrm{CH}_{3}\right)$; HR ESMS $m / z$ (\% rel. int.) $349.2358\left(\mathrm{M}+\mathrm{Na}^{+}\right)$. Calcd. for $\mathrm{C}_{19} \mathrm{H}_{34} \mathrm{NaO}_{4}$, 349.2354 .

\section{Biological procedures}

\section{Cell culture}

Human A549 non small lung carcinoma cells were cultured in RPMI 1640 supplemented with $10 \%$ FCS, glutamine, and antibiotics as previously described. ${ }^{[20]}$ Human ovarian carcinomas A2780 and A2780AD (MDR overexpressing P-glycoprotein) were cultured as above with the addition of 0.25 units $/ \mathrm{mL}$ of bovine insulin.

Cytotoxicity assays, indirect immunofluorescence and cell cycle

Cytotoxic evaluation was performed with A2780 and A2780AD cells with the MTT assay modified as previously described. ${ }^{[25]}$ Indirect immunofluorescence was performed in A549 cells that had been cultured overnight in $12 \mathrm{~mm}$ round coverslips and incubated a further 24 hours in the absence (drug vehicle DMSO) or in the presence of different ligand concentrations. Attached cells were permeabilized with Triton X100 and fixed with $3.7 \%$ formaldehyde. Microtubules were specifically stained with DM1A $\alpha$-tubulin monoclonal antibodies and DNA with Hoechst 33342 as previously described. ${ }^{[26]}$ The preparations were examined using a Zeiss axioplan epifluorescence microscope and the images were recorded in a Hamamatsu 4742-95 cooled CCD camera. Progression through the cell cycle analysis was assesed by flow cytometry DNA determination with propidium iodide. Cells were fixed, treated with RNase and stained with propidium iodide as previously described. ${ }^{[27]}$ Analysis was performed in a Coulter Epics XL flow cytometer.

\section{Tubulin assembly inhibition assay}

The effect of the compounds in the assembly of purified tubulin was determined by incubating $20 \mu \mathrm{M}$ purified tubulin at $37^{\circ} \mathrm{C}$ for 30 minutes in GAB (glycerol assembling buffer, $3.4 \mathrm{M}$ glycerol, $10 \mathrm{mM}$ sodium phospate, $1 \mathrm{mM}$ EGTA, $1 \mathrm{mM} \mathrm{GTP}, 6 \mathrm{mM} \mathrm{MgCl} 2$ at $\mathrm{pH}$ 6.5) in the presence of 25 $\mu \mathrm{M}$ docetaxel, $100 \mu \mathrm{M}$ of one of the analogs PTA-PF or JPP or $2 \mu \mathrm{L}$ DMSO (vehicle). The samples were processed and the critical concentration for tubulin assembly ${ }^{[22]}$ in the presence of the ligands calculated as described. ${ }^{[27]}$

Supporting Information (see footnote on the first page of this article): experimental procedures and preparation of pyrones 4,5 and $\mathbf{6}$, and of all required synthetic intermediates. Graphical ${ }^{1} \mathrm{H}$ and ${ }^{13} \mathrm{C}$ NMR spectra of all new compounds.

\section{Acknowledgments}

Financial support has been granted to M. C. by the Spanish Ministry of Education and Science (projects CTQ2008-02800 and CTQ2011-27560), by the Consellería d'Empresa, Universitat i Ciencia de la Generalitat Valenciana (ACOMP09/113) and by the BANCAJA-UJI Foundation (P11B2002-06, P1-1B-2008-14 and PI-1B2011-37). The biological work has been supported in part by grants from the Spanish Ministry of Education and Science (BIO2010-16351) and from the Comunidad de Madrid (grant S2010/BMD-2457 BIPEDD2-CM), both to J.F.D.. We further thank the Matadero Municipal Vicente de Lucas in Segovia for providing the calf brains which were the source of tubulin.
Figure 1. Structures of two natural products reported to selectively bind to $\alpha$-tubulin.

Figure 2. Schematic model of the covalent union of pironetin to its binding site at the $\alpha$-tubulin surface.

Figure 3. General structures of simplified pironetin analogues [17].

Figure 4. Structures of new pironetin analogues.

Figure 5. Effect of compounds 3-6 as compared to the parent molecule pironetin on the microtubule network and nucleus morphology of A549 cells. Cells were incubated for 24 hours with either drug vehicle DMSO ( A,B) , $50 \mathrm{nM}$ pironetin (C,D), $100 \mu \mathrm{M} 3$ (E,F), $25 \mu \mathrm{M} 4$ (G,H), $15 \mu \mathrm{M} 5$ $(\mathrm{I}, \mathrm{J})$ and $200 \mu \mathrm{M} 6(\mathrm{~K}, \mathrm{~L})$. Microtubules are stained with $\alpha$-tubulin antibodies (A, C, E, G, I, K) whereas DNA ((B,C,F,H,J,L) was stained with Hoechst 33342. Insets $(A, B, C, D, K, L)$ are mitotic spindles of the same preparation. The scale bar (L) represents $10 \mu \mathrm{m}$. All panels and insets have the same magnification.

Figure 6. Cell cycle histogram of A549 lung carcinoma cells untreated and treated with pironetin and pironetin analogues of 3-6 .The lowest ligand concentration that induces maximal effect on the cell cycle is depicted.

Scheme 1. Synthesis of pyrones 3-6. (a) (-)- $\mathrm{Ipc}_{2} \mathrm{BCl}$, allylMgBr, $\mathrm{Et}_{2} \mathrm{O}$, $-78^{\circ} \mathrm{C}, 1 \mathrm{~h}$, then addition of $n$-decanal, $2 \mathrm{~h},-78^{\circ} \mathrm{C}, 95 \%$ (e.r. $96: 4$ ); (b) $\mathrm{NaH}$, THF, $0^{\circ} \mathrm{C}$, then MeI, RT, overnight, $92 \%$; (c) $\mathrm{O}_{3}, \mathrm{CH}_{2} \mathrm{Cl}_{2},-78^{\circ} \mathrm{C}$; (d) $(+)-\mathrm{Ipc}_{2} \mathrm{BCl}$, allylMgBr, $\mathrm{Et}_{2} \mathrm{O},-78^{\circ} \mathrm{C}, 1 \mathrm{~h}$, followed by addition of the aldehyde, $2 \mathrm{~h},-78^{\circ} \mathrm{C}(70 \%$ overall from 8, d.r. 88:12); (e) TBSOTf, $\mathrm{CH}_{2} \mathrm{Cl}_{2}, 2$,6-lutidine, RT, $1 \mathrm{~h}(90 \%)$; (f) $\mathrm{O}_{3}, \mathrm{CH}_{2} \mathrm{Cl}_{2},-78^{\circ} \mathrm{C}$, then $\mathrm{PPh}_{3}$; (g) $(-)-\mathrm{Ipc}_{2} \mathrm{BCl}$, allylMgBr, $\mathrm{Et}_{2} \mathrm{O},-78^{\circ} \mathrm{C}, 1 \mathrm{~h}$, followed by addition of the aldehyde, $2 \mathrm{~h},-78^{\circ} \mathrm{C}(47 \%$ overall yield from 11, d.r.>95:5); (h) $\mathrm{CH}_{2}=\mathrm{CHCOCl}, \mathrm{CH}_{2} \mathrm{Cl}_{2}, i \mathrm{Pr}_{2} \mathrm{NEt},-78{ }^{\circ} \mathrm{C}, 45 \mathrm{~min}(77 \%)$; (i) (1) $10 \%$ cat. Ru-I, $\mathrm{CH}_{2} \mathrm{Cl}_{2}, \Delta, 4 \mathrm{~h}(85 \%)$; (2) PPTS (cat.), $\mathrm{MeOH}, \Delta$, overnight (90\%). Acronyms and abbreviations: TBS, tert-butyldimethylsilyl; PPTS, pyridinium $p$-toluenesulfonate; Ipc, isopinocampheyl; Tf, trifluoromethanesulfonyl.

[1] T. Fojo, Ed. The Role of Microtubules in Cell Biology, Neurobiology and Oncology; Humana Press: Totowa, New Jersey, 2008.

[2] (a) L. A. Amos, Org. Biomol. Chem. 2004, 2, 2153-2160. (b) R. H. Wade, Mol. Biotechnol. 2009, 43, 177-191.

[3] (a) E. Nogales, H.-W. Wang, Curr. Opin. Cell Biol. 2006, 18, 179184. (b) E. Nogales, H.-W. Wang, Curr. Opin. Struct. Biol. 2006, 16, 221-229.

[4] (a) T. Beckers, S. Mahboobi, Drugs Fut. 2003, 28, 767-785. (b) J. A. Hadfield, S. Ducki, N. Hirst, A. T. McGown, Progr. Cell Cycle Res. 2003, 5, 309-325. (c) M. A. Jordan, L. Wilson, Nat. Rev. Cancer 2004, 4, 253-265. (d) S.-H. Chen, J. Hong, Drugs Fut. 2006, 31, 123 150. (e) E. Pasquier, M. Kavallaris, IUBMB Life 2008, 60, 165-170. (f) P. Singh, K. Rathinasamy, R. Mohan, D. Panda, IUBMB Life 2008, 60, 368-375. (g) P. G. Morris, M. N. Fornier, Clin. Cancer Res. 2008, 14, 7167-7172. (h) E. A. Perez, Mol. Cancer Ther. 2009, 8, 2086-2095. (i) S. M. Chen, L.-H. Meng, J. Ding, Expert Opin. Invest. Drugs 2010, 19, 329-343. (j) D. Calligaris, P. Verdier-Pinard, F. Devred, C. Villard, D. Braguer, D. Lafitte, Cell. Mol. Life Sci. 2010, 67, 1089-1104. (k) S. S. Goyal, R. M. Patel, P. S. Sukhramani, K. A. Kamothi, Int. J. Pharm. Sci. Res. 2010, 1, 1-21.

[5] (a) K.-H. Altmann, J. Gertsch, Nat. Prod. Rep. 2007, 24, 327-357. (b) D. G. I. Kingston, J. Org. Chem. 2008, 73, 3975-3984. (c) D. G. I. Kingston, J. Nat. Prod. 2009, 72, 507-515.

[6] J. Chen, T. Liu, X. Dong, Y. Hu, Mini-Rev. Med. Chem. 2009, 9 , 1174-1190. 
[7] Y. Fu, S. Li, Y. Zu, G.Yang, Z. Yang, M. Luo, S. Jiang, M. Wink, T. Efferth, Curr. Med. Chem. 2009, 16, 3966-3985.

[8] (a) M. A. Jordan, Curr. Med. Chem.-Anticancer Drugs 2002, 2, 1-17. (b) M. Abal, J. M. Andreu, I. Barasoain, Curr. Cancer Drug Targets 2003, 3, 193-203.

[9] (a) J. J. Correia, S. Lobert, Curr. Pharm. Des. 2001, 7, 1213-1228. (b) J. Jiménez-Barbero, F. Amat-Guerri, J. P. Snyder, Curr. Med. Chem.-Anticancer Drugs 2002, 2, 91-122. (c) J. F. Díaz, J. M Andreu, J. Jiménez-Barbero, Top. Curr. Chem. 2009, 286, 121-149. (d) B. Gigant, A. Cormier, A. Dorléans, R. B. G. Ravelli, M Knossow, Top. Curr. Chem. 2009, 286, 259-278. (e) E. M. Daly, R. E. Taylor, Curr. Chem. Biol. 2009, 3, 367-379.

[10] (a) V. M. Sánchez-Pedregal, C. Griesinger, Top. Curr. Chem. 2009, 286, 151-208. (b) J. H. Nettles, K. H. Downing, Top. Curr. Chem. 2009, 286, 209-257. (c) M. Botta, S. Forli, M. Magnani, F. Manetti, Top. Curr. Chem. 2009, 286, 279-328.

[11] F. Sarabia, M. García-Castro, A. Sánchez-Ruiz, Curr. Bioact. Comp. 2006, 2, 269-299.

[12] H. J. Anderson, J. E. Coleman, R. J. Andersen, M. Roberge, Cancer Chemother. Pharmacol. 1997, 39, 223-226.

[13] (a) M. Kondoh, T. Usui, S. Kobayashi, K. Tsuchiya, K. Nishikawa, T. Nishikiori, T. Mayumi, H. Osada, Cancer Lett. 1998, 126, 29-32. (b) M. Kondoh, T. Usui, T. Nishikiori, T. Mayumi, H. Osada, Biochem. J. 1999, 340, 411-416. (c) H. Watanabe, H. Watanabe, T. Usui, M Kondoh, H. Osada, T. Kitahara, J. Antibiot. 2000, 53, 540-545. (d) T. Usui, H. Watanabe, H. Nakayama, Y. Tada, N. Kanoh, M. Kondoh, T. Asao, K. Takio, H. Watanabe, K. Nishikawa, T. Kitahara, H. Osada, Chem. \& Biol. 2004, 11, 799-806.

[14] (a) K. Yasui, Y. Tamura, K. Nakatani, K. Kawada, M. Ohtani, J. Org. Chem. 1995, 60, 7567-7574. (b) M. K. Gurjar, J. T. Henri, Jr., D. S. Bose, A. V. R. Rao, Tetrahedron Lett. 1996, 37, 6615-6618. (c) N. Chida, M. Yoshinaga, T. Tobe, S. Ogawa, Chem. Comm. 1997, 1043-1044. (d) H. Watanabe, H. Watanabe, M. Bando, M. Kido, T. Kitahara, Tetrahedron 1999, 55, 9755-9776. (e) G. E. Keck, C. E. Knutson, S. A. Wiles, Org. Lett. 2001, 3, 707-710. (f) L. C. Dias, L. G. de Oliveira, M. A. de Sousa, Org. Lett. 2003, 5, 265-268. (g) X Shen, A. S. Wasmuth, J. Zhao, C. Zhu, S. G. Nelson, J. Am. Chem. Soc. 2006, 128, 7438-7439. (h) D. Enders, S. Dhulut, D. Steinbusch, A. Herrbach, Chem. Eur. J. 2007, 13, 3942-3949. (i) C. Bressy, J.-P. Vors, S. Hillebrand, S. Arseniyadis, J. Cossy, Angew. Chem. Int. Ed. 2008, 47, 10137-10140. (j) M. T. Crimmins, A.-M. R. Dechert, Org. Lett. 2009, 11, 1635-1638.

[15] (a) A. Vogt, P. A. McPherson, X.-Q. Shen, R. Balachandran, G.-Y. Zhu, B. S. Raccor, S. G. Nelson, M. Tsang, B. W. Day, Chem. Biol. Drug Des. 2009, 74, 358-368. (b) J. Lin, X. Yue, P. Huang, D. Cui, F.-L. Qing, Synlett 2010, 267-275.

[16] M. Kavallaris, Nat. Rev. Cancer 2010, 10, 194-204.

[17] J. A. Marco, J. García-Pla, M. Carda, J. Murga, E. Falomir, C. Trigili, S. Notararigo, J. F. Díaz, I. Barasoain, Eur. J. Med. Chem. 2011, 46 $1630-1637$.

[18] (a) P. V. Ramachandran, G.-M. Chen, H. C. Brown, Tetrahedron Lett. 1997, 38, 2417-2420. (b) Ramachandran, P. V. Pinane-Based Versatile "Allyl" boranes. Aldrichimica Acta 2002, 35, 23-35.

[19] For general reviews on metathesis, with particular emphasis in RCM, see: (a) A. Fürstner, Angew. Chem. Int. Ed. 2000, 39, 3012-3043. (b) L. Jafarpour, S. P. Nolan, Adv. Organometal. Chem. 2000, 46, 181222. (c) T. M. Trnka, R. H. Grubbs, R. H., Acc. Chem. Res. 2001, 34, 18-29. (d) Handbook of Metathesis (Ed: R. H. Grubbs), Wiley-VCH, Weinheim, 2003. (e) R. H. Grubbs, Tetrahedron 2004, 60, 7117 7140. (f) D. Astruc, New J. Chem. 2005, 29, 42-56. (g) A. H. Hoveyda, A. R. Zhugralin, Nature 2007, 450, 243-251. (h) Metathesis in Natural Product Synthesis (Eds: J. Cossy, S Arseniyadis, C. Meyer), Wiley-VCH, Weinheim, 2010.

[20] R. M. Buey, E. Calvo, I. Barasoain, O. Pineda, M. C. Edler, R. Matesanz, G. Cerezo, C. D. Vanderwal, B. W. Day, E. J. Sorensen, J. A. López, J. M. Andreu, E. Hamel, J. F. Díaz, Nature Chem. Biol. 2007, 3, 117-125.

[21] M.A. Jordan, D. Thrower, L. Wilson, J. Cell Sci. 1992. 102, 401-416.

[22] F. Oosawa, S. Asakura, Thermodynamics of the Polymerization of Proteins. Academic Press, London, 1975.
[23] (a) $R$ enantiomer: W. R. Roush, L. K. Hoong, M. A. J. Palmer, J. C. Park, J. Org. Chem. 1990, 55, 4109-4117: $[\alpha]_{\mathrm{D}}+5.3\left(\right.$ c 1.2; $\left.\mathrm{CHCl}_{3}\right)$ with $86 \%$ ee. (b) $S$ enantiomer: N. Gogoi, J. Boruwa, N. C. Barua Eur. J. Org. Chem. 2006, 1722-1725: $[\alpha]_{1}-12.3$ (c 0.9; $\mathrm{CH}_{2} \mathrm{Cl}_{2}$ ) with $94 \%$ ee; R. S. C. Kumar, E. Sreedhar, G. V. Reddy, K. S. Babu, J. M. Rao, Tetrahedron: Asymmetry 2009, 20, 1160-1163: $[\alpha]_{\mathrm{D}}-7.5$ (c $1 ; \mathrm{CHCl}_{3}$ ) with $92 \%$ ee.

[24] T. Miura, Y. Masaki, J. Chem. Soc. Perkin Trans. I 1995, 2155-2158.

[25] C. Yang, I. Barasoain, X. Li, R. Matesanz, R. Liu, F. J. Sharom, D. L. Yin, J. F. Díaz, W. S. Fang, ChemMedChem. 2007, 2, 691-701.

[26] C. De Inés, D. Leynadier, I. Barasoain, V. Peyrot, P. Garcia, C. Briand, G. A. Rener, C. Temple, Jr., Cancer Res. 1994, 54, 75-84.

[27] R. M. Buey, I. Barasoain, E. Jackson, A. Meyer, P. Giannakakou, I. Paterson, S. Mooberry, J. M. Andreu, J. F. Díaz, Chem. \& Biol. 2005, 12, 1269-1279.

Received: ((will be filled in by the editorial staff)) Published online: ((will be filled in by the editorial staff)) 


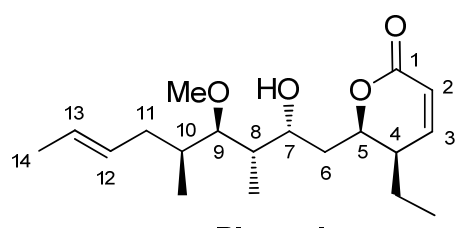

Pironetin

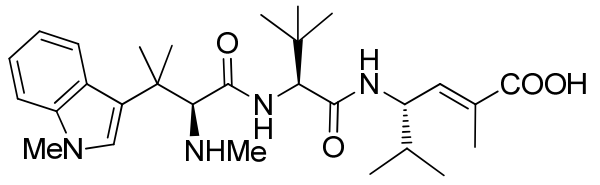

Hemiasterlin

Figure 1
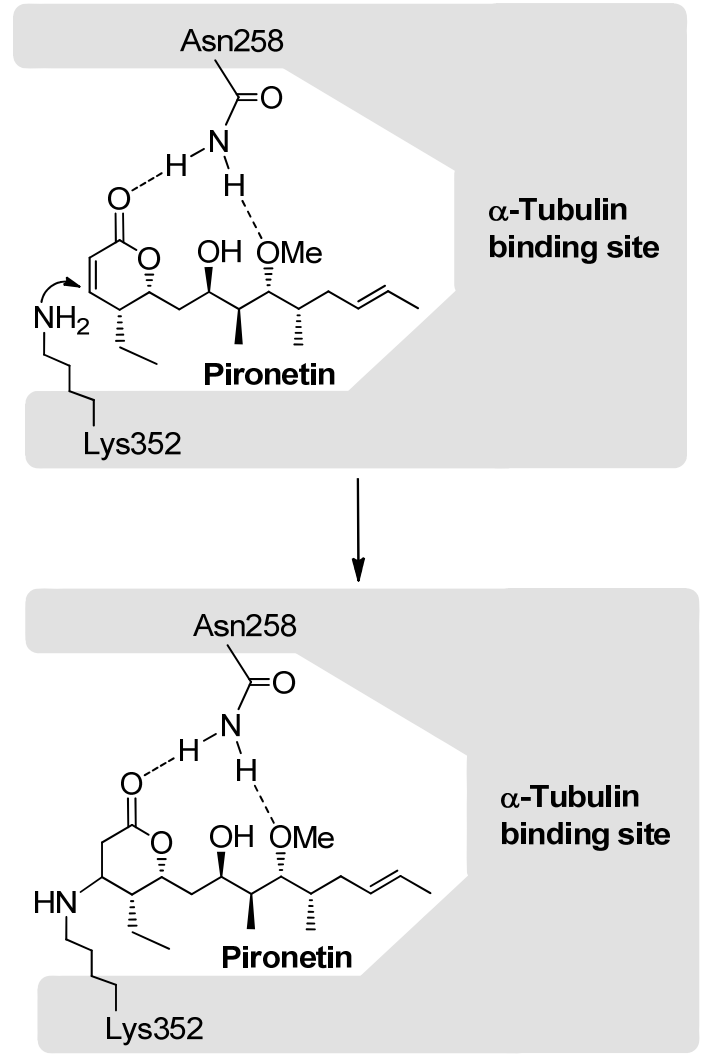

Figure 2

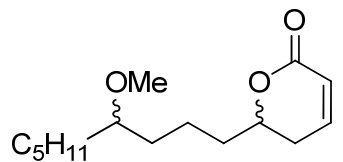

1

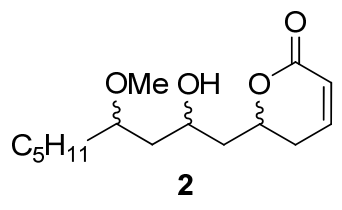

2<smiles>CO[C@H](C[C@@H]1CC=CC(=O)O1)C[C@@H](O)C1CCC1C</smiles>

3

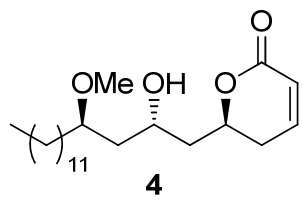<smiles>CO[C@H](C[C@@H]1CC=CC(=O)O1)C[C@H](C)C(C)(C)C</smiles>

Figure 4<smiles>CO[C@H](C[C@@H]1CC=CC(=O)O1)C[C@@H](OC)c1ccccc1</smiles>
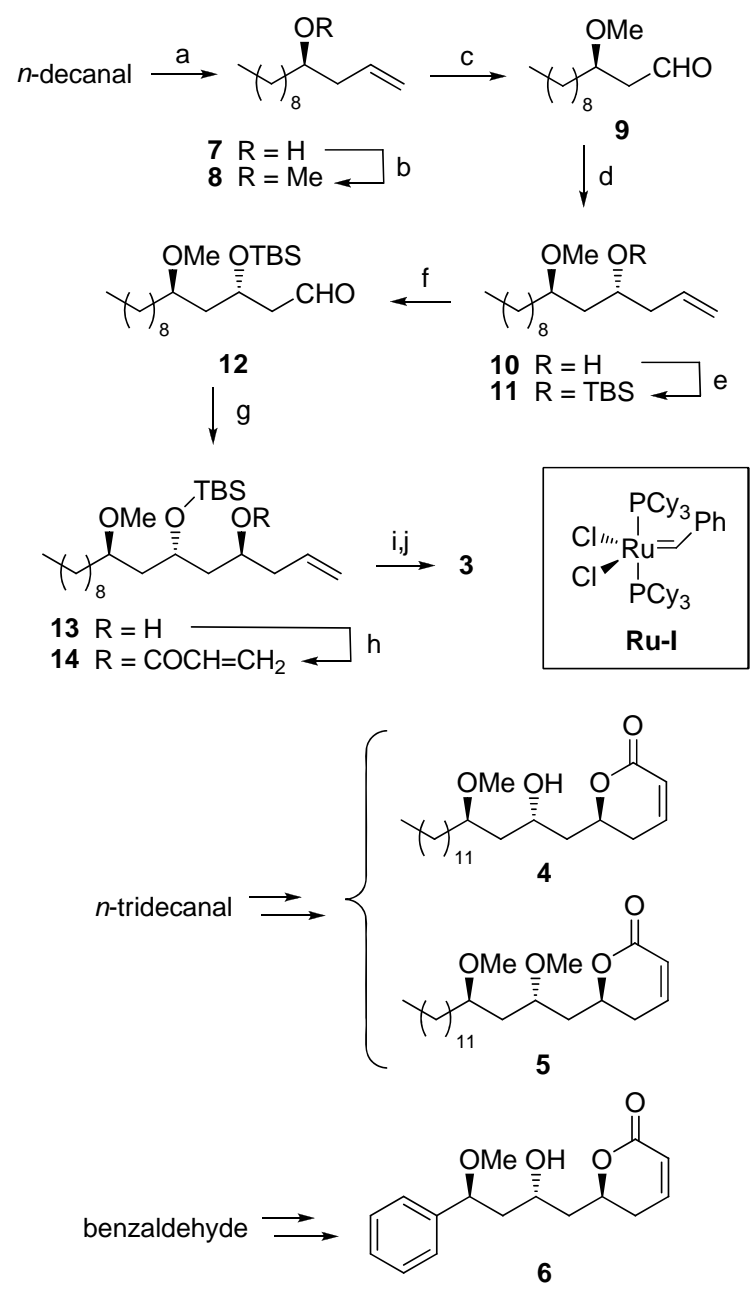

Scheme 1

Figure 3

TABLES 
Table 1. Effect of pironetin analogues 3-6 on the growth of A2780 and A2780AD (MDR overexpressing P-glycoprotein) ovarian carcinomas. $^{\text {a }}$

\begin{tabular}{|c|c|c|c|}
\hline Ligand & $\mathrm{A} 2780(\mu \mathrm{M})^{\mathrm{b}}$ & $\mathrm{A} 2780 \mathrm{AD}(\mu \mathrm{M})^{\mathrm{b}}$ & $\mathrm{R} / \mathrm{S}^{\mathrm{c}}$ \\
\hline Pironetin & $0.0062 \pm 0.0012$ & $0.0093 \pm 0.0014$ & 1.5 \\
\hline $\mathbf{3}$ & $39.7 \pm 0.5$ & $38.6 \pm 1.1$ & 0.97 \\
\hline $\mathbf{4}$ & $14.1 \pm 0.424$ & $12.5 \pm 0.353$ & 0.90 \\
\hline $\mathbf{5}$ & $9.2 \pm 0.3$ & $10.9 \pm 0.05$ & 1.2 \\
\hline $\mathbf{6}$ & $54.7 \pm 5.4$ & $48 \pm 0.7$ & 0.9 \\
\hline
\end{tabular}

${ }^{\mathrm{a}} \mathrm{IC}_{50}(50 \%$ inhibition of cell proliferation) of the ligands determined in ovarian carcinomas.

${ }^{\mathrm{b}}$ Values mean $\mathrm{IC}_{50}$ as the mean \pm standard error of three independent experiments

${ }^{\mathrm{c}}$ Resistance index (the relative resistance of A2780AD cell line, obtained dividing the $\mathrm{IC}_{50}$ of the resistant cell line by that of the parental A2780 cell line).
Table 2. Critical concentration values of tubulin for ligand-induced microtubule assembly induced by tetrahydrofuran derivatives 3-6 (ligand concentrations are $25 \mu \mathrm{M}$ for docetaxel and $100 \mu \mathrm{M}$ for the ligands).

\begin{tabular}{|c|c|}
\hline Ligand & $\mathrm{Cr}(\mu \mathrm{M})^{\mathrm{a}}$ \\
\hline Control & $3.3 \pm 0.3$ \\
\hline Docetaxel & $1.3 \pm 0.4$ \\
\hline $\mathbf{3}$ & $3.8 \pm 0.9$ \\
\hline $\mathbf{4}$ & $4.3 \pm 1.3$ \\
\hline $\mathbf{5}$ & $4.9 \pm 0.8$ \\
\hline $\mathbf{6}$ & $3.5 \pm 0.8$ \\
\hline
\end{tabular}

${ }^{a} \mathrm{Cr}$ values are the mean \pm standard error of three independent experiments. 

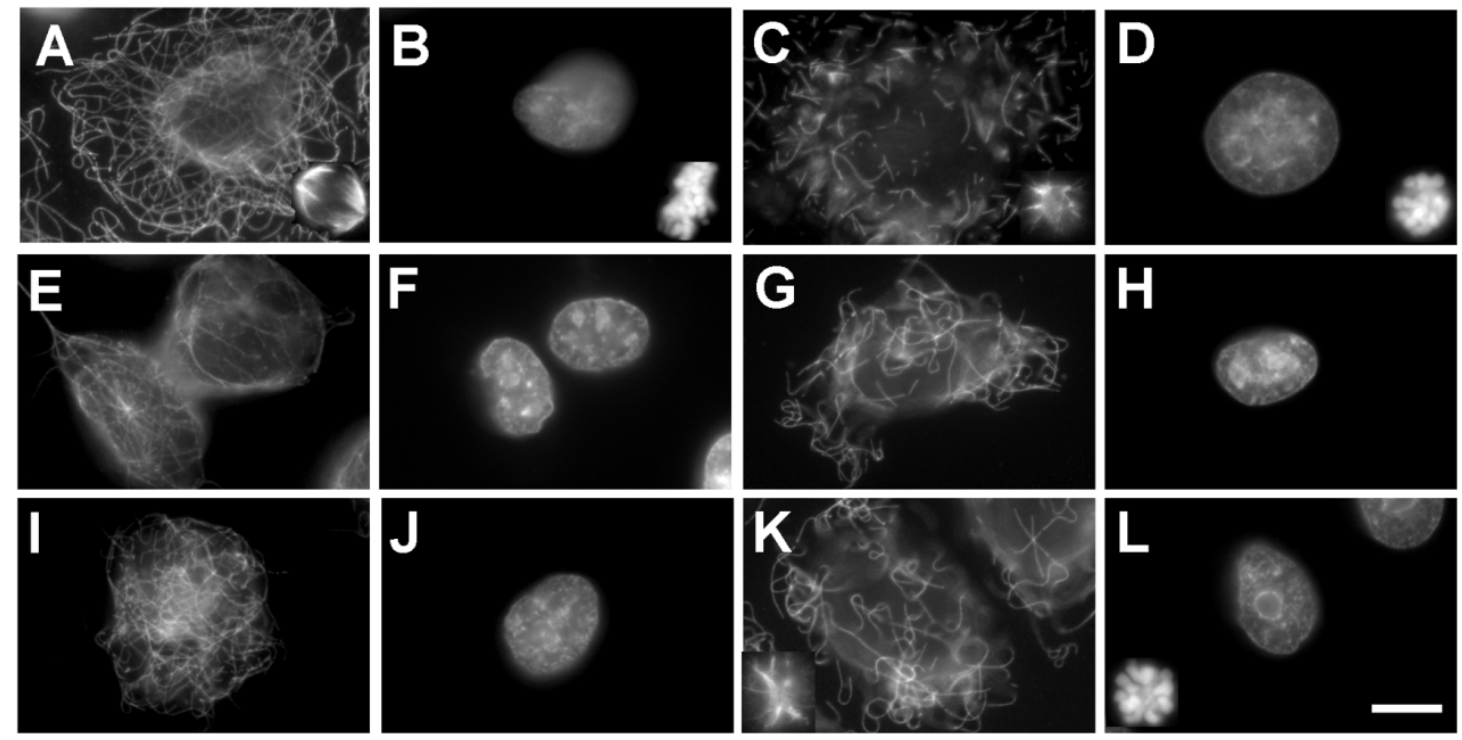

Figure 5
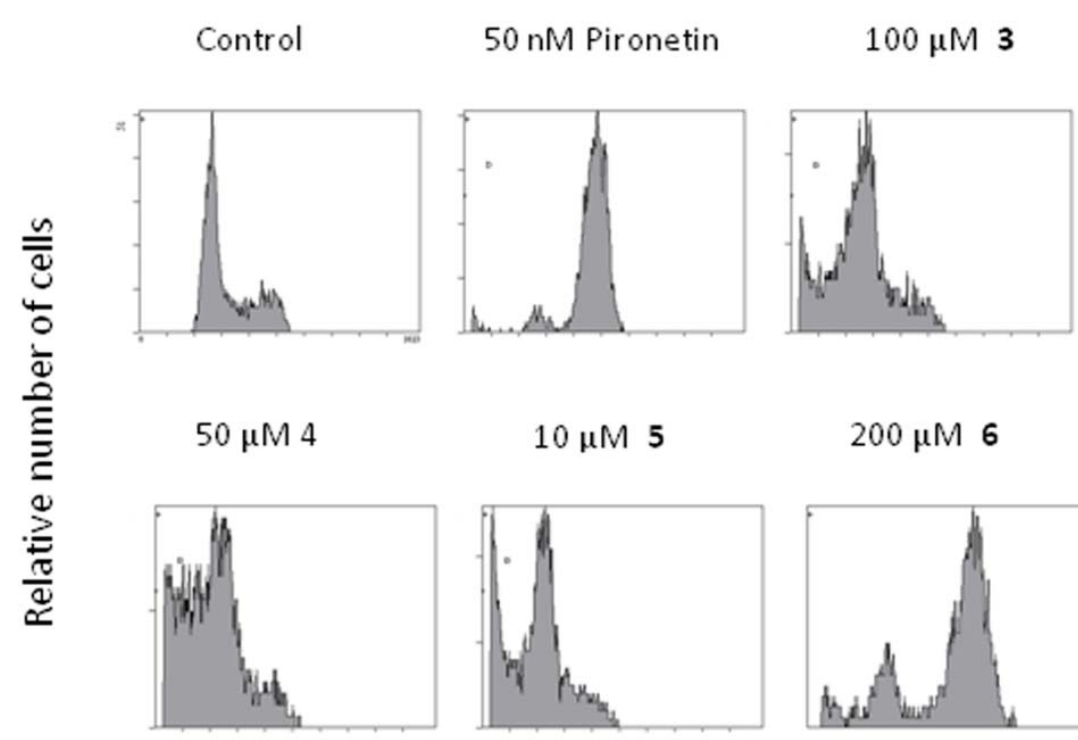

$10 \mu \mathrm{M} 5$

$200 \mu \mathrm{M} 6$
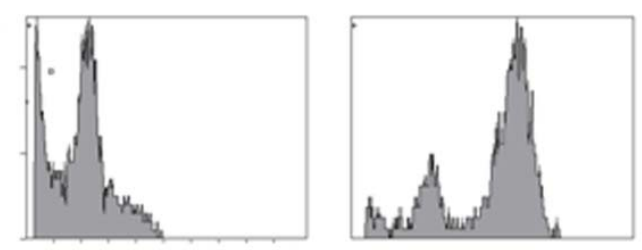

Relative DNA content (PI fluorescence)

Figure 6 
Entry for the Table of Contents (Please choose one layout)

\section{Layout 1:}

((Key Topic))

The preparation of four new analogues of the natural pyrone pironetin, known to bind to $\alpha$-tubulin, is described. The nine-carbon side chain of pironetin has been replaced in one analogue by a 4phenylbutyl chain and in the other three analogues by long aliphatic chains of thirteen and sixteen carbons, all of them bearing two stereogenic centers. Their cytotoxic activity and their interactions with tubulin have been investigated.

\section{Pironetin analogues}

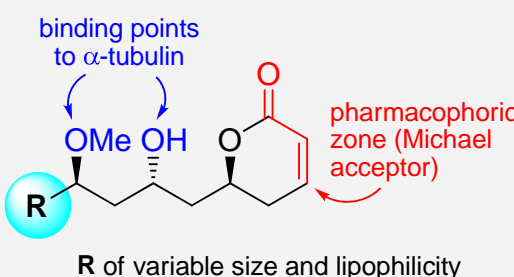

$\mathbf{R}$ of variable size and lipophilicity
Miguel Carda,* Juan Murga, Eva Falomir, Santiago Díaz-Oltra, Jorge García-Pla, Julián Paños, Chiara Trigili, J. Fernando Díaz,* Isabel Barasoain,* and J. Alberto Marco* Page No. - Page No.

Synthesis and biological evaluation of $\alpha$ tubulin-binding pironetin analogues with enhanced lipophilicity

Keywords: Tubulin / Microtubules / Microtubule-disrupting Compounds / Cytotoxicity / Lipophilic Pironetin Analogues

\section{Layout 2:}




\section{Synthesis and biological evaluation of pironetin analogues with enhanced lipophilicity}

Miguel Carda, ${ }^{\dagger}$ Juan Murga, ${ }^{\dagger}$ Eva Falomir, ${ }^{\dagger}$ Santiago Díaz-Oltra, ${ }^{\dagger}$ Jorge García-Pla, $^{\dagger}$ Julián Paños, $^{\dagger}$ Chiara Trigili, $^{\S}$ J. Fernando Díaz, ${ }^{\S}$ Isabel Barasoain $^{\S}$ and J. Alberto Marco ${ }^{\ddagger}$

${ }^{\dagger}$ Depart. de Q. Inorgánica y Orgánica, Univ. Jaume I, 12080 Castellón, Spain; ${ }^{\S}$ CIB, CSIC, 28040 Madrid, Spain; and ${ }^{\ddagger}$ Depart. de Q. Orgánica, Univ. de Valencia, 46100 Burjassot, Valencia, Spain

\section{Supporting Information}

Contents:

S-2/S-3: $\quad$ General procedures

S-4/S-5: Synthetic schemes

S-6/S-14: Synthesis and analytical data of intermediate and final compounds 
General features. NMR spectra were measured at $25{ }^{\circ} \mathrm{C}$. The signals of the deuterated solvent $\left(\mathrm{CDCl}_{3}\right)$ were taken as the reference. Multiplicity assignments of ${ }^{13} \mathrm{C}$ signals were made by means of the DEPT pulse sequence. High resolution mass spectra were run by the electrospray mode (ESMS). IR data were measured with oily films on $\mathrm{NaCl}$ plates (oils) or $\mathrm{KBr}$ pellets (solids) and are given only for molecules with relevant functional groups $(\mathrm{OH}, \mathrm{C}=\mathrm{O})$. Optical rotations were measured at $25{ }^{\circ} \mathrm{C}$. Experiments which required an inert atmosphere were carried out under dry $\mathrm{N}_{2}$ in a flame-dried glassware. $\mathrm{Et}_{2} \mathrm{O}$ and THF were freshly distilled from sodium/benzophenone ketyl and transferred via syringe. Dichloromethane was freshly distilled from $\mathrm{CaH}_{2}$. Tertiary amines were freshly distilled from $\mathrm{KOH}$. Commercially available reagents were used as received. Unless detailed otherwise, "work-up" means pouring the reaction mixture into brine, followed by extraction with the solvent indicated in parenthesis. If the reaction medium was acidic (basic), an additional washing with $5 \%$ aq $\mathrm{NaHCO}_{3}$ (aq $\mathrm{NH}_{4} \mathrm{Cl}$ ) was performed. New washing with brine, drying over anhydrous $\mathrm{Na}_{2} \mathrm{SO}_{4}$ and elimination of the solvent under reduced pressure were followed by chromatography on a silica gel column $(60-200 \mu \mathrm{m})$ with the indicated eluent. Where solutions were filtered through a Celite pad, the pad was additionally washed with the same solvent used, and the washings incorporated to the main organic layer. Acronyms used hereafter: DIP-Cl $=$ diisopinocampheylboron chloride; TBS $=t$-butyldimethylsilyl; $\mathrm{Tf}$ $=$ trifluoromethanesulfonyl; PPTS = pyridinium $p$-toluenesulfonate; DMAP = 4-(N,N-dimethylamino $)$ pyridine.

\section{General reaction conditions (see schemes A-C)}

General procedure for asymmetric allylations (reaction $+a$ ). Allylmagnesium bromide (commercial $1 \mathrm{M}$ solution in $\mathrm{Et}_{2} \mathrm{O}, 10 \mathrm{~mL}, 10 \mathrm{mmol}$ ) was added dropwise under $\mathrm{N}_{2}$ via syringe to a solution of $(+)$ DIP-Cl (3.85 g, $12 \mathrm{mmol})$ in dry $\mathrm{Et}_{2} \mathrm{O}(50 \mathrm{~mL})$ cooled at $-78^{\circ} \mathrm{C}$. After replacing the latter by an ice bath, the mixture was stirred for $1 \mathrm{~h}$. The solution was then allowed to stand, which caused precipitation of magnesium chloride. The supernatant solution was then carefully transferred to another flask via canula. After cooling this flask at $-78^{\circ} \mathrm{C}$, a solution of the appropriate aldehyde (8 mmol) in dry $\mathrm{Et}_{2} \mathrm{O}(25 \mathrm{~mL})$ was added dropwise via syringe. The resulting solution was further stirred at the same temp. for $1 \mathrm{~h}$. The reaction mixture was then quenched through addition of phosphate $\mathrm{pH} 7 \mathrm{buffer}$ solution $(50 \mathrm{~mL}), \mathrm{MeOH}(50 \mathrm{~mL})$ and $30 \% \mathrm{H}_{2} \mathrm{O}_{2}(25 \mathrm{~mL})$. After stirring for $30 \mathrm{~min}$., the mixture was poured onto satd. aq $\mathrm{NaHCO}_{3}$ and worked up $\left(\mathrm{Et}_{2} \mathrm{O}\right)$. Column chromatography on silica gel (hexanes$\mathrm{Et}_{2} \mathrm{O}$ or hexanes-EtOAc mixtures) afforded the desired homoallylic alcohol. Reaction $-a$ is performed in the same way except for the use of (-)-DIP-Cl.

General procedure for sequential ozonolysis/asymmetric allylation (reaction $+b$ or $-b$ ). The appropriate olefin $(10 \mathrm{mmol})$ was dissolved in dry $\mathrm{CH}_{2} \mathrm{Cl}_{2}(100 \mathrm{~mL})$ and cooled to $-78^{\circ} \mathrm{C}$. A stream of ozone-oxygen was bubbled through the solution until persistence of the bluish color. Dry $\mathrm{N}_{2}$ was then bubbled through the solution for $10 \mathrm{~min}$. at the same temperature. After addition of $\mathrm{PPh}_{3}(5.25 \mathrm{~g}, 20$ $\mathrm{mmol}$ ), the solution was left to stir at room temp. for $2 \mathrm{~h}$. Solvent removal under reduced pressure gave a solid material, which was washed three times with cold pentane (3 x $15 \mathrm{~mL})$. The solid $\left(\mathrm{Ph}_{3} \mathrm{PO}\right)$ was discarded, and the organic phase was evaporated under reduced pressure to yield the crude aldehyde as 
a colorless oil, which was used as such in the asymmetric allylation (for weight calculations, the yield of the ozonolysis step was assumed to be quantitative). The overall process is described as $+b$ or $-b$ according to the use of (+)- or (-)-DIP-Cl in the allylation step.

General procedure for $\boldsymbol{O}$-methylations (reaction $c$ ). Sodium hydride (60\% slurry in mineral oil, amount equivalent to $24 \mathrm{mmol}$ ) was washed two times under $\mathrm{N}_{2}$ with dry hexane and once with dry THF. Then, THF (80 mL) was added and the suspension was cooled in an ice bath. The appropriate alcohol (12 mmol) was then dissolved in dry THF $(20 \mathrm{~mL})$ and added dropwise to the sodium hydride suspension. The mixture was then allowed to reach room temperature. Subsequently, methyl iodide ( $2.25 \mathrm{~mL}, 36 \mathrm{mmol}$ ) was added in one portion and the mixture was stirred overnight at room temp. Work-up $\left(\mathrm{Et}_{2} \mathrm{O}\right)$ was followed by column chromatography on silica gel (hexanes- $\mathrm{Et}_{2} \mathrm{O}$ or hexanesEtOAc mixtures) to afford the desired $O$-methyl ether.

General procedure for silylations with TBSOTf (reaction $d$ ). The appropriate alcohol (4 mmol) was dissolved under $\mathrm{N}_{2}$ in dry $\mathrm{CH}_{2} \mathrm{Cl}_{2}(20 \mathrm{~mL})$ and treated sequentially with 2,6-lutidine (700 $\left.\mu \mathrm{L}, 6 \mathrm{mmol}\right)$ and TBSOTf (1.15 mL, $5 \mathrm{mmol})$. The reaction mixture was then stirred for $1 \mathrm{~h}$ at room temp. and worked up (extraction with $\mathrm{CH}_{2} \mathrm{Cl}_{2}$ ). Column chromatography on silica gel (hexanes- $\mathrm{Et}_{2} \mathrm{O}$ or hexanesEtOAc mixtures) afforded the desired silylated derivative.

General procedure for acylations with acryloyl chloride (reaction $e$ ). The appropriate alcohol (1 mmol) was dissolved under $\mathrm{N}_{2}$ in dry $\mathrm{CH}_{2} \mathrm{Cl}_{2}(40 \mathrm{~mL})$, cooled to $-78^{\circ} \mathrm{C}$ and treated sequentially with ethyl diisopropylamine (2.6 mL, $15 \mathrm{mmol})$ and acryloyl chloride (800 $\mu \mathrm{L}, 10 \mathrm{mmol})$. The reaction mixture was stirred for $2 \mathrm{~h}$ at $-78^{\circ} \mathrm{C}$ and then worked up (extraction with $\mathrm{CH}_{2} \mathrm{Cl}_{2}$ ). Column chromatography on silica gel (hexanes- $\mathrm{Et}_{2} \mathrm{O}$ or hexanes-EtOAc mixtures) afforded the desired ester.

General procedure for ring-closing metathesis with ruthenium catalyst Ru-I (reaction $f$ ). The appropriate diolefin (1 mmol) was dissolved under $\mathrm{N}_{2}$ in dry, degassed $\mathrm{CH}_{2} \mathrm{Cl}_{2}(100 \mathrm{~mL})$ and treated with Grubbs first-generation ruthenium catalyst Ru-I (82 mg, $0.1 \mathrm{mmol}$ ). The mixture was heated at reflux until consumption of the starting material (2-4 h, TLC monitoring!). Solvent removal under reduced pressure and column chromatography of the residue on silica gel (hexanes- $\mathrm{Et}_{2} \mathrm{O}$ or hexanesEtOAc mixtures) furnished the desired metathesis product.

General procedure for acid-catalyzed desilylation (reaction $\mathrm{g}$ ). The silylated compound (0.6 mmol) was dissolved in $\mathrm{MeOH}(30 \mathrm{~mL})$ and treated with PPTS (30 mg, $0.12 \mathrm{mmol})$ and water $(0.3 \mathrm{~mL})$. The mixture was then heated at reflux for $18 \mathrm{~h}$, cooled and neutralized by addition of solid $\mathrm{NaHCO}_{3}$. After filtering, the solution was evaporated under reduced pressure, and the oily residue was subjected to column chromatography on silica gel (hexanes-EtOAc mixtures). This provided the desired hydroxy compound.

Procedure for $\boldsymbol{O}$-methylation of compound 4 (Scheme B). See details in page S-13. 


\section{Synthetic schemes}

Scheme A

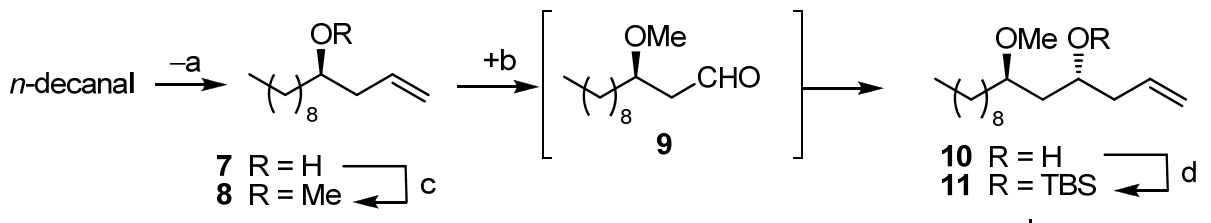

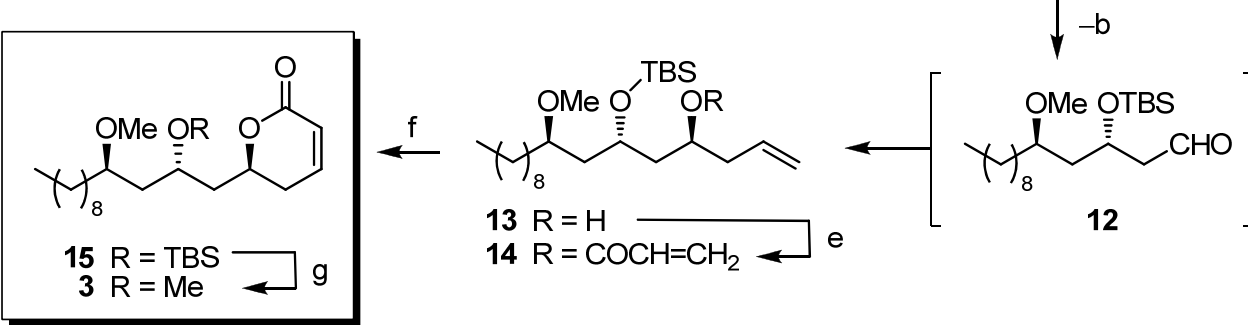

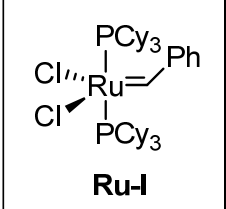

\section{Scheme B}
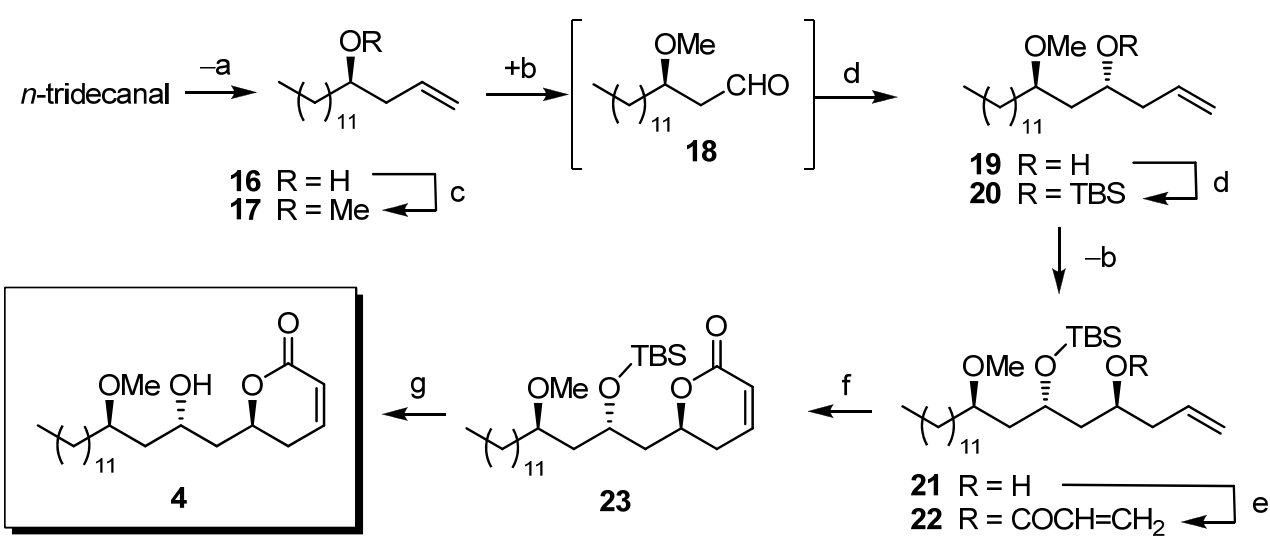

see pag. S-13

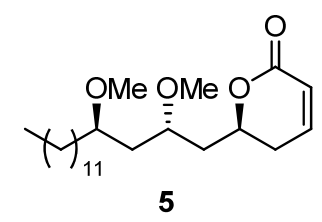




\section{Scheme C}

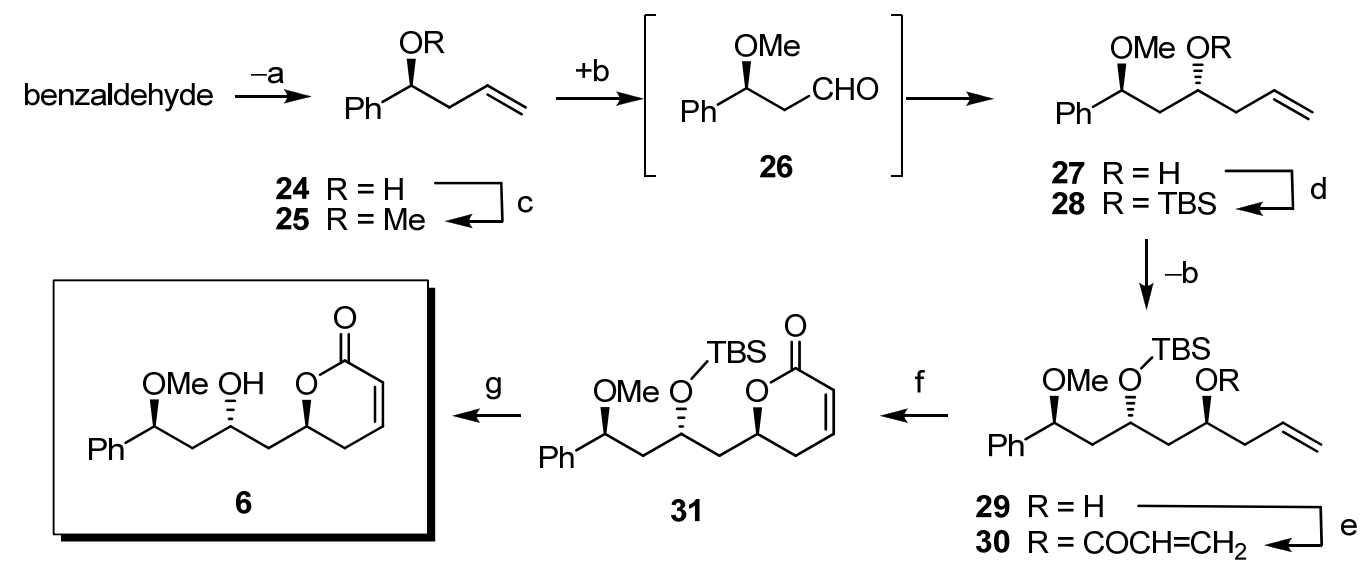




\section{$\underline{\text { Synthesis and analytical data of intermediate and final compounds }}$}

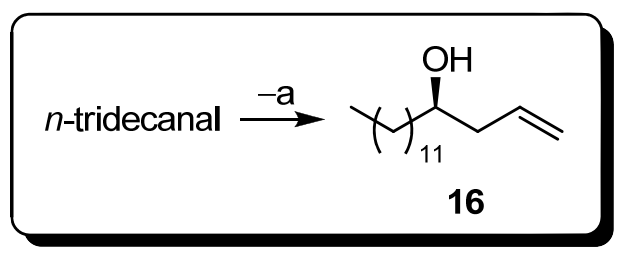

(R)-Hexadec-1-en-4-ol (16). Prepared in 93\% yield from $n$-tridecanal according to experimental conditions $-a$ (pag. S-2): oil; $[\alpha]_{\mathrm{D}}+2.8\left(c 1 ; \mathrm{CHCl}_{3}\right)$. Spectral data as reported*. The enantiomeric ratio was found to be 90:10 by means of chiral HPLC using a Kromasil 5-AmyCoat column (4.6 x $20 \mathrm{~mm}$ ). Elution was performed with a hexane/isopropanol 99:1 mixture, and a flux of $0.4 \mathrm{~mL} / \mathrm{min}$. Elution times of both enantiomers: $18.33(S)$ and $20.39 \min (R)$.

* $R$ and S enantiomer: Wetzel, I.; Krauss, J.; Bracher, F. Lett. Org. Chem. 2012, 9, 169-174. For the $R$ enantiomer: $[\alpha]_{\mathrm{D}}+4.2\left(c\right.$ 1.9; $\left.\mathrm{CH}_{2} \mathrm{Cl}_{2}\right)$ with $99 \%$ ee.

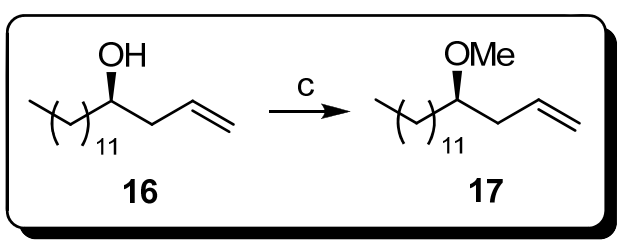

(R)-4-Methoxyhexadec-1-ene (17). Prepared from 16 in 90\% yield according to experimental conditions $c$ (pag. S-3): oil; $\left.[\alpha]_{\mathrm{D}}+2.8(c) ; \mathrm{CHCl}_{3}\right) ;{ }^{1} \mathrm{H}$ NMR $(500 \mathrm{MHz}) \delta 5.82(1 \mathrm{H}$, ddt, $J=17.5$, 10.5, $7 \mathrm{~Hz}$ ), 5.10-5.00 (2H, br m), 3.34 (3H, s), 3.20 (1H, quint, $J \sim 6 \mathrm{~Hz}$ ), 2.26 (2H, m), 1.50-1.35 (4H, br m), 1.35-1.25 (18H, br m), 0.89 (3H, t, $J=7 \mathrm{~Hz}) ;{ }^{13} \mathrm{C}$ NMR (125 MHz) $\delta 135.0,80.8(\mathrm{CH}), 116.7$, 37.8, 33.4, 31.9, 29.8-29.4 (several overlapped signals), 25.3, $22.7\left(\mathrm{CH}_{2}\right)$, 56.5, $14.1\left(\mathrm{CH}_{3}\right)$; HR ESMS $\mathrm{m} / \mathrm{z}$ (\% rel. int.) $277.2512\left(\mathrm{M}+\mathrm{Na}^{+}\right)$. Calcd. for $\mathrm{C}_{17} \mathrm{H}_{34} \mathrm{NaO}, 277.2507$.

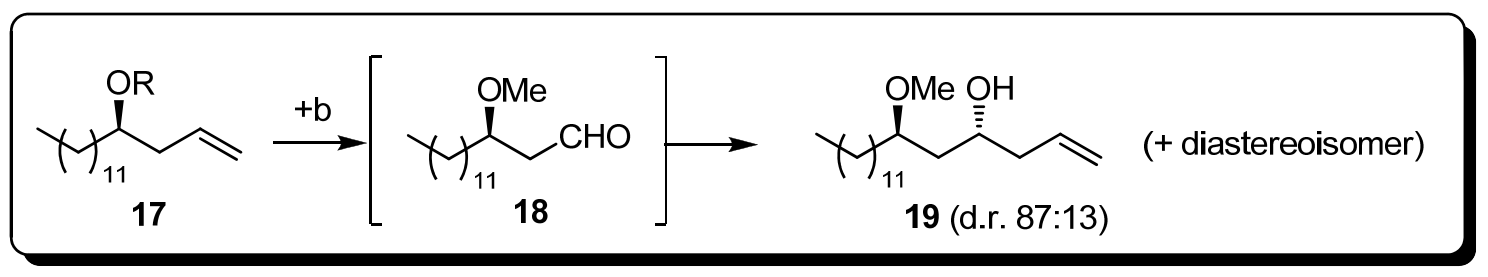

(4R,6R)-6-Methoxyoctadec-1-en-4-ol (19). Prepared in two steps from 17 (via the non isolated aldehyde 18) in $72 \%$ overall yield according to experimental conditions $+b$ (pag. S-2). The isolated 
compound was an 87:13 mixture of diastereoisomers which were very difficult to separate and was used as such in the next step. For analytical purposes, an aliquot could be concentrated to about 95\% purity by means of careful column chromatography: oil; $[\alpha]_{\mathrm{D}}-18.8$ (c 1, $\mathrm{CHCl}_{3}$ ); IR $v_{\max } 3400$ (br, $\mathrm{OH}) \mathrm{cm}^{-1}$; ${ }^{1} \mathrm{H}$ NMR (500 MHz) $\delta 5.85(1 \mathrm{H}, \mathrm{ddt}, J=17,10.3,7.2 \mathrm{~Hz}), 5.15-5.05$ (2H, br m), $3.95(1 \mathrm{H}$, m), $3.47(1 \mathrm{H}, \mathrm{m}), 3.37$ (3H, s), 2.80 (1H, br s, OH), $2.24(2 \mathrm{H}, \mathrm{m}), 1.70-1.40(4 \mathrm{H}, \mathrm{br} \mathrm{m}), 1.35-1.25$ (20H, br m), 0.89 (3H, t, $J=7 \mathrm{~Hz}$ ); ${ }^{13} \mathrm{C}$ NMR (125 MHz) $\delta$ 135.0, 79.3, $68.0(\mathrm{CH}), 117.5,42.3,39.0$, 33.1, 31.9, 29.8-29.4 (several overlapped signals), 25.4, $22.7\left(\mathrm{CH}_{2}\right)$, 56.7, $14.1\left(\mathrm{CH}_{3}\right)$; HR ESMS $\mathrm{m} / \mathrm{z}$ (\% rel. int.) $321.2775\left(\mathrm{M}+\mathrm{Na}^{+}\right)$. Calcd. for $\mathrm{C}_{19} \mathrm{H}_{38} \mathrm{NaO}_{2}, 321.2769$.

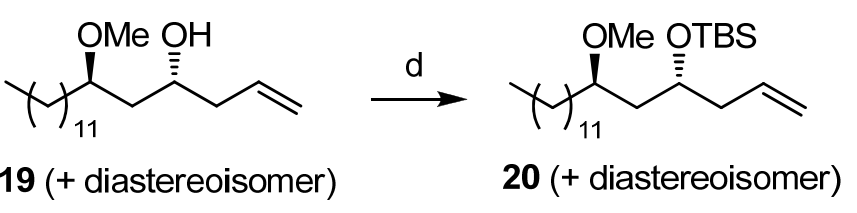

(4R,6R)-4-(Tert-butyldimethylsilyloxy)-6-methoxyoctadec-1-ene (20). Prepared from 19 in 93\% yield according to experimental conditions $d$ (pag. S-3). Like 19, the isolated 20 was a 87:13 mixture of diastereoisomers which were very difficult to separate and was used as such in the next step. For analytical purposes, an aliquot could be concentrated to about $95 \%$ purity by means of careful column chromatography: oil; $[\alpha]_{\mathrm{D}}-6.8\left(c \mathrm{1}, \mathrm{CHCl}_{3}\right) ;{ }^{1} \mathrm{H}$ NMR $(500 \mathrm{MHz}) \delta 5.82(1 \mathrm{H}, \mathrm{ddt}, J=17,10,7 \mathrm{~Hz})$, 5.10-5.05 (2H, br m), $3.93(1 \mathrm{H}, \mathrm{m}), 3.34(1 \mathrm{H}, \mathrm{m}), 3.30$ (3H, s), $2.24(2 \mathrm{H}, \mathrm{m}), 1.60-1.40$ (4H, br m), 1.35-1.25 (20H, br m), $0.90(12 \mathrm{H}$, strong singlet of $9 \mathrm{H}$ overlapping a methyl triplet at $0.89 \mathrm{ppm}), 0.08$ (6H, s); ${ }^{13} \mathrm{C}$ NMR (125 MHz) $\delta 18.1$ (C), 134.8, 77.1, 68.7 (CH), 116.9, 42.8, 41.7, 33.1, 31.9, 29.929.4 (several overlapped signals), 24.8, $22.7\left(\mathrm{CH}_{2}\right)$, 55.6, 26.0 (x 3), 14.1, -4.1, -4.7 $\left(\mathrm{CH}_{3}\right)$. HR ESMS $\mathrm{m} / \mathrm{z}$ (\% rel. int.) $413.3816\left(\mathrm{M}+\mathrm{H}^{+}\right)$. Calcd. for $\mathrm{C}_{25} \mathrm{H}_{53} \mathrm{O}_{2} \mathrm{Si}$, 413.3815.

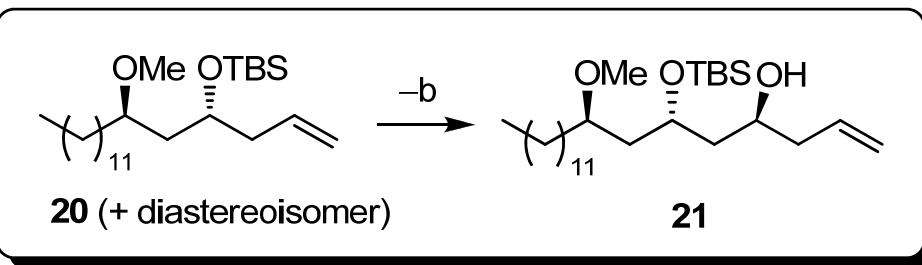

(4S,6R,8R)-6-(Tert-butyldimethylsilyloxy)-8-methoxyicos-1-en-4-ol (21). Prepared in two steps from 20 (via a non isolated intermediate aldehyde) in $80 \%$ overall yield according to experimental conditions $-b$ (pag. S-2). The isolated compound was a 72:28 mixture of diastereoisomers which, after careful chromatographic purification on silica gel (hexanes-EtOAc 98:2), yielded the major component 21 as a 
pure compound: oil; $[\alpha]_{\mathrm{D}}-3.9$ (c 1.3; $\left.\mathrm{CHCl}_{3}\right)$; IR $v_{\max } 3440$ (br, OH) $\mathrm{cm}^{-1} ;{ }^{1} \mathrm{H}$ NMR (500 MHz) $\delta$ 5.84 (1H, ddt, $J=17,10,7 \mathrm{~Hz}), 5.15-5.05(2 \mathrm{H}$, br m), $4.18(1 \mathrm{H}, \mathrm{m}), 4.04(1 \mathrm{H}, \mathrm{m}), 3.50(1 \mathrm{H}, \mathrm{br} \mathrm{s}, \mathrm{OH})$, 3.29 (3H, s), 3.25 (1H, m), 2.30-2.15 (2H, br m), 1.75-1.40 (6H, br m), 1.35-1.25 (20H, br m), 0.90 (9H, s), 0.88 (3H, t, $J=6.8 \mathrm{~Hz}$ ), $0.13(3 \mathrm{H}, \mathrm{s}), 0.10$ (3H, s); ${ }^{13} \mathrm{C}$ NMR (125 MHz) $\delta 17.9(\mathrm{C}), 135.0$, 77.3, 69.3, 68.0 (CH), 117.1, 42.4, 42.1, 41.0, 32.8, 31.9, 29.9-29.4 (several overlapped signals), 24.6, $22.7\left(\mathrm{CH}_{2}\right)$, 55.6, 25.9 (x 3), 14.1, -4.4, -4.9 $\left(\mathrm{CH}_{3}\right)$. HR ESMS m/z (\% rel. int.) $457.4080\left(\mathrm{M}^{+} \mathrm{H}^{+}\right)$. Calcd. for $\mathrm{C}_{27} \mathrm{H}_{57} \mathrm{O}_{3} \mathrm{Si}$, 457.4077 .

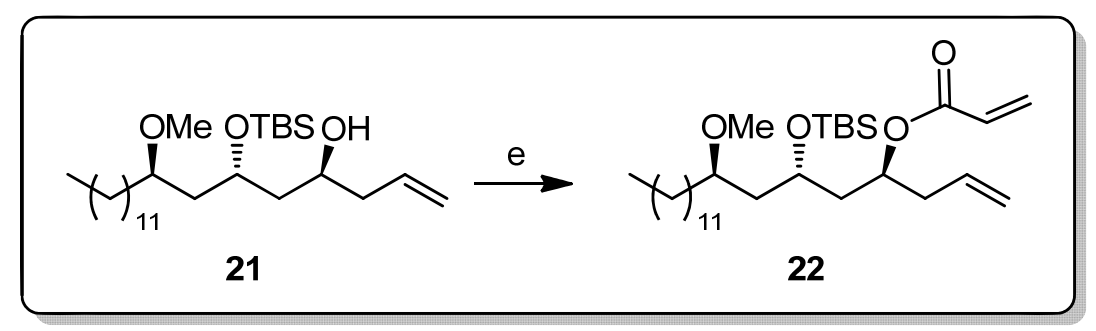

(4S,6S,8R)-6-(Tert-butyldimethylsilyloxy)-8-methoxyicos-1-en-4-yl acrylate (22). Prepared from 21 in 79\% yield according to experimental conditions $e$ (pag. S-3): oil; $[\alpha]_{\mathrm{D}}+2.1$ (c 1.1; $\mathrm{CHCl}_{3}$ ); IR $v_{\max }$ $1726(\mathrm{C}=\mathrm{O}) \mathrm{cm}^{-1}$; ${ }^{1} \mathrm{H}$ NMR (500 MHz) $\delta 6.37(1 \mathrm{H}, \mathrm{dd}, J=17.3,1.5 \mathrm{~Hz}), 6.10(1 \mathrm{H}, \mathrm{dd}, J=17.3,10.7$ Hz), 5.80 (1H, dd, $J=10.7,1.5 \mathrm{~Hz}), 5.76$ (1H, ddt, $J=17,10.2,7 \mathrm{~Hz}), 5.10-5.05$ (3H, br m), $3.85(1 \mathrm{H}$, m), 3.29 (3H, s), 3.28 (1H, m), 2.45-2.35 (2H, m), 1.85-1.40 (6H, br m), 1.35-1.25 (20H, br m), 0.89 $(12 \mathrm{H}$, strong singlet of $9 \mathrm{H}$ overlapping a methyl triplet at $0.89 \mathrm{ppm}), 0.05(3 \mathrm{H}, \mathrm{s}), 0.04(3 \mathrm{H}, \mathrm{s}) ;{ }^{13} \mathrm{C}$ NMR (125 MHz) $\delta$ 165.7, 18.0 (C), 133.4, 129.0, 77.5, 71.2, 67.0 (CH), 130.2, 118.0, 42.7, 42.0, 39.0, 33.2, 31.9, 29.9-29.4 (several overlapped signals), 24.7, $22.7\left(\mathrm{CH}_{2}\right), 55.8,26.0$ (x 3), 14.1, -4.3, -4.4 $\left(\mathrm{CH}_{3}\right)$; HR ESMS m/z (\% rel. int.) $533.4003\left(\mathrm{M}+\mathrm{Na}^{+}\right.$). Calcd. for $\mathrm{C}_{30} \mathrm{H}_{58} \mathrm{NaO}_{4} \mathrm{Si}, 533.4002$.

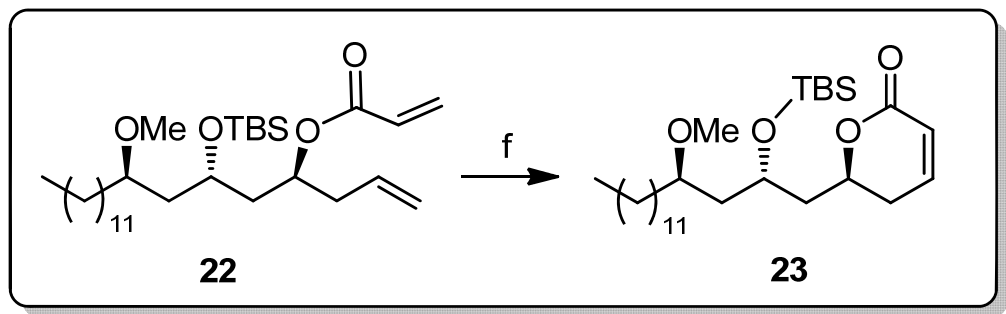

(6S)-6-[(2S,4R)-2-(Tert-butyldimethylsilyloxy)-4-methoxyhexadecyl]-5,6-dihydro-2H-pyran-2-one (23). Prepared from 22 in 85\% yield according to experimental conditions $f$ (pag. S-3): oil; $[\alpha]_{D}-5.6$ ( $c$ 1.1, $\left.\mathrm{CHCl}_{3}\right)$; IR $v_{\max } 1735(\mathrm{C}=\mathrm{O}) \mathrm{cm}^{-1} ;{ }^{1} \mathrm{H} \mathrm{NMR}(500 \mathrm{MHz}) \delta 6.87(1 \mathrm{H}, \mathrm{dt}, J=9.8,4 \mathrm{~Hz}), 6.00(1 \mathrm{H}, \mathrm{br}$ 
d, $J=9.8 \mathrm{~Hz}$ ), 4.59 (1H, m), 4.07 (1H, m), 3.29 (3H, s), 3.24 (1H, quint, $J \sim 6 \mathrm{~Hz}), 2.35-2.30$ (2H, m), $2.03(1 \mathrm{H}, \mathrm{m}), 1.65-1.40$ (5H, br m), 1.35-1.20 (20H, br m), 0.88 (12H, strong singlet of 9H overlapping a methyl triplet at $0.88 \mathrm{ppm}), 0.09$ (3H, s), 0.07 (3H, s); ${ }^{13} \mathrm{C}$ NMR (125 MHz) $\delta 164.2,18.0$ (C), 145.1, 121.5, 77.7, 74.6, 66.2 (CH), 43.4, 43.3, 33.2, 31.9, 29.9-29.4 (several overlapped signals), 24.7, 22.6 $\left(\mathrm{CH}_{2}\right)$, 55.8, 25.9 (x 3), 14.1, -4.4, -4.5 ( $\left.\mathrm{CH}_{3}\right)$; HR ESMS m/z (\% rel. int.) 505.3696 (M+Na ${ }^{+}$). Calcd. for $\mathrm{C}_{28} \mathrm{H}_{54} \mathrm{NaO}_{4} \mathrm{Si}$, 505.3689 .

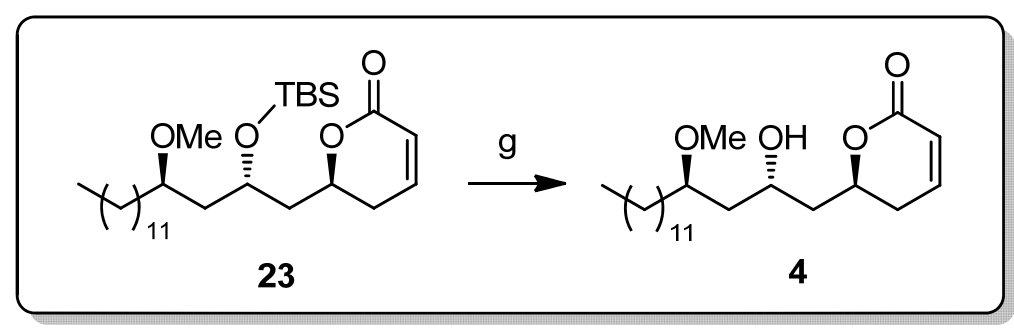

(6S)-6-[(2S,4R)-2-Hydroxy-4-methoxyhexadecyl]-5,6-dihydro-2H-pyran-2-one (4). Prepared from 23 in 85\% yield according to experimental conditions $g$ (pag. S-3): oil; $[\alpha]_{\mathrm{D}}-13.1$ (c 1.1, $\mathrm{CHCl}_{3}$ ); IR $v_{\max } 3440$ (br, OH), $1716(\mathrm{C}=\mathrm{O}) \mathrm{cm}^{-1}$; ${ }^{1} \mathrm{H}$ NMR $(500 \mathrm{MHz}) \delta 6.86(1 \mathrm{H}, \mathrm{m}), 6.00(1 \mathrm{H}, \mathrm{br} \mathrm{d}, J=9.7 \mathrm{~Hz})$, $4.72(1 \mathrm{H}, \mathrm{m}), 4.22(1 \mathrm{H}, \mathrm{m}), 3.45(1 \mathrm{H}, \mathrm{m}), 3.34(3 \mathrm{H}, \mathrm{s}), 3.15(1 \mathrm{H}, \mathrm{br} \mathrm{s}, \mathrm{OH}), 2.45-2.30$ (2H, br m), 1.90 1.40 (6H, br m), 1.35-1.20 (20H, br m), 0.87 (3H, t, $J=6.8 \mathrm{~Hz}) ;{ }^{13} \mathrm{C}$ NMR (125 MHz) $\delta 164.4(\mathrm{C})$, 145.2, 121.3, 79.5, 75.1, $64.6(\mathrm{CH}), 42.9,39.4,32.8,31.9,30.0,29.7,29.6$, 29.5-29.4 (several overlapped signals), 29.3, 25.5, $22.6\left(\mathrm{CH}_{2}\right)$, 56.6, $14.0\left(\mathrm{CH}_{3}\right)$; HR ESMS m/z (\% rel. int.) 391.2827 $\left(\mathrm{M}+\mathrm{Na}^{+}\right)$. Calcd. for $\mathrm{C}_{22} \mathrm{H}_{40} \mathrm{NaO}_{4}, 391.2824$.

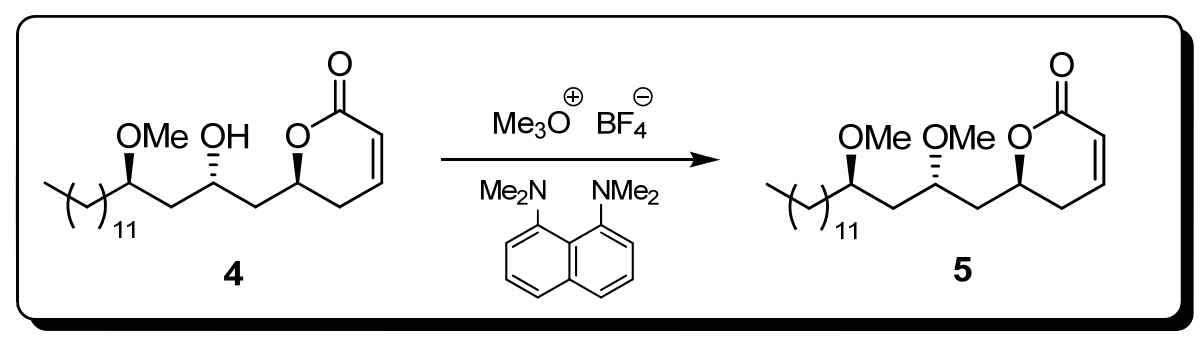

(6S)-6-[(2S,4R)-2,4-Dimethoxyhexadecyl]-5,6-dihydro-2H-pyran-2-one (5). A solution of pyrone 4 (37 mg, $0.1 \mathrm{mmol}$ ) and 1,8-bis( $N, N$-dimethylamino)naphthalene (129 mg, $0.6 \mathrm{mmol})$ in dry $\mathrm{CH}_{2} \mathrm{Cl}_{2}$ (4 $\mathrm{mL}$ ) was treated under $\mathrm{N}_{2}$ with trimethyloxonium tetrafluoroborate (89 $\mathrm{mg}, 0.6 \mathrm{mmol}$ ). The mixture was then stirred at room temperature for $7 \mathrm{~h}$ and quenched by addition of a saturated solution of $\mathrm{NaCl}$. Work up (extraction with $\mathrm{CH}_{2} \mathrm{Cl}_{2}$ ) and column chromatography of the residue on silica gel (hexanes- 
EtOAc 7:3) afforded 5 (25 mg, 65\%): oil; $[\alpha]_{\mathrm{D}}-16.3$ (c 0.95, $\left.\mathrm{CHCl}_{3}\right)$; IR $v_{\max } 1726(\mathrm{C}=\mathrm{O}) \mathrm{cm}^{-1} ;{ }^{1} \mathrm{H}$ NMR (500 MHz) $\delta 6.88(1 \mathrm{H}, \mathrm{m}), 6.00(1 \mathrm{H}, \mathrm{br} \mathrm{d}, J=9.7 \mathrm{~Hz}), 4.65(1 \mathrm{H}, \mathrm{m}), 3.68(1 \mathrm{H}, \mathrm{m}), 3.41$ (3H, s), 3.33 (3H, s), 3.30 (1H, m), 2.40-2.30 (2H, br m), 1.96 (1H, m), 1.75-1.40 (5H, br m), 1.35-1.20 (20H, br m), $0.88(3 \mathrm{H}, \mathrm{t}, J=7 \mathrm{~Hz}) ;{ }^{13} \mathrm{C}$ NMR $(125 \mathrm{MHz}) \delta 164.4(\mathrm{C}), 145.1,121.5,77.8,74.9,74.4(\mathrm{CH})$, 41.3, 39.8, 33.5, 31.9, 29.9-29.3 (several overlapped signals), 24.8, $22.7\left(\mathrm{CH}_{2}\right)$, 57.9, 56.2, $14.1\left(\mathrm{CH}_{3}\right)$; HR ESMS m/z (\% rel. int.) $405.2976\left(\mathrm{M}+\mathrm{Na}^{+}\right)$. Calcd. for $\mathrm{C}_{23} \mathrm{H}_{42} \mathrm{NaO}_{4}, 405.2980$. 


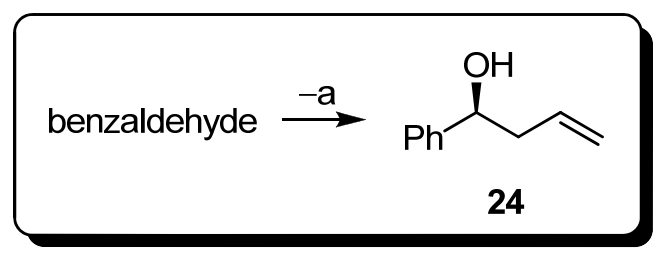

(S)-1-Phenyl-3-buten-1-ol (24). Prepared by means of asymmetric allylboration of benzaldehyde according to the reported procedure:* oil, $[\alpha]_{\mathrm{D}}-38.4\left(\right.$ ( $\left.1.1 ; \mathrm{CHCl}_{3}\right)$.

*Brown, H. C.; Jadhav, P. K. J. Am. Chem. Soc. 1983, 105, 2092-2093: $[\alpha]_{D}-44.9$ (c 7.38; $\left.\mathrm{C}_{6} \mathrm{H}_{6}\right)$.

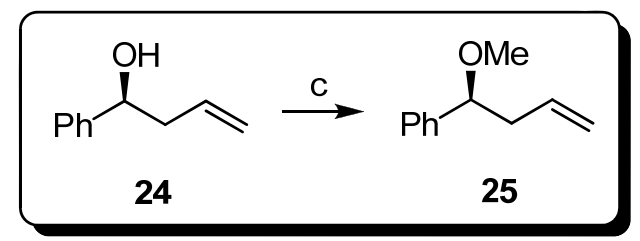

(R)-1-Methoxy-1-phenyl-3-butene (25). Prepared from 24 in 95\% yield according to experimental conditions $c$ (pag. S-3): Spectral data as reported*.

* (a) Hermans, B.; Hevesi, L. J. Org. Chem. 1995, 60, 6141-6147. (b) von Schrader, T.; Woodward, S. Eur. J. Org. Chem. 2002, 3833-3836.

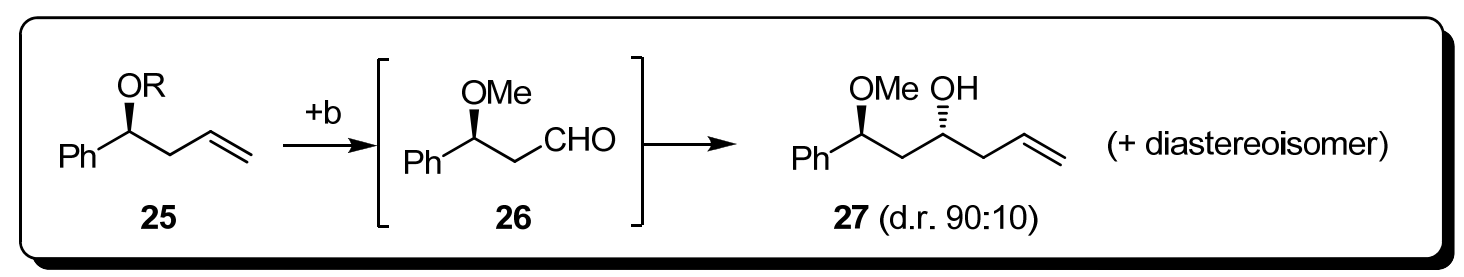

(1S,3R)-1-Methoxy-1-phenylhex-5-en-3-ol (27). Prepared in two steps from 25 (via the non isolated aldehyde 26) in 85\% overall yield according to experimental conditions $+b$ (pag. S-2). The isolated compound was a 90:10 mixture of diastereoisomers which was separated by means of column chromatography on silica gel (hexanes-EtOAc 95:5) to yield 27 as the major compound*: oil; $[\alpha]_{\mathrm{D}}-77$ (c 1, $\mathrm{CHCl}_{3}$ ); IR $v_{\max } 3440$ (br, OH) cm ${ }^{-1}$; ${ }^{1} \mathrm{H}$ NMR (500 MHz) $\delta 7.40-7.25$ (5H, br m), 5.85 (1H, ddt, $J=17,10,7 \mathrm{~Hz}$ ), 5.15-5.05 (2H, br m), 4.50 (1H, dd, $J=8.8,3.5 \mathrm{~Hz}), 3.95$ (1H, m), 3.27 (3H, s), 2.65 (1H, br s, OH), 2.30-2.20 (2H, m), 1.92 (1H, ddd, $J=14.5,8.8,2.8 \mathrm{~Hz}), 1.77$ (1H, ddd, $J=14.5,8.8$, $3.5 \mathrm{~Hz}$ ); ${ }^{13} \mathrm{C}$ NMR (125 MHz) $\delta 141.8$ (C), 134.8, 128.5 (x 2), 127.5, 126.3 (x 2), 81.1, $67.6(\mathrm{CH})$, 117.6, 44.4, $42.0\left(\mathrm{CH}_{2}\right)$, $56.7\left(\mathrm{CH}_{3}\right)$; HR ESMS m/z (\% rel. int.) $229.1203\left(\mathrm{M}+\mathrm{Na}^{+}\right)$. Calcd. for $\mathrm{C}_{13} \mathrm{H}_{18} \mathrm{NaO}_{2}, 229.1204$. 
* Compound 27 in admixture with its syn diastereoisomer has been previously reported in racemic form: Hoffmann, R.; Brückner, R. Chem. Ber. 1992, 125, 1471-1484.

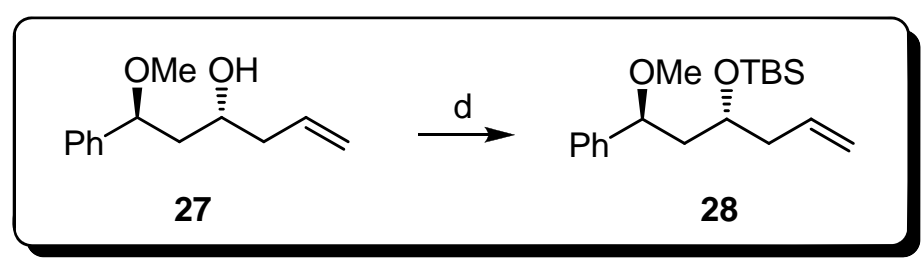

(1R,3R)-3-(Tert-butyldimethylsilyloxy)-1-methoxyhex-5-ene (28). Prepared from 27 in 92\% yield according to experimental conditions $d$ (pag. S-3): oil; $[\alpha]_{\mathrm{D}}-62.3$ (c 1.2, $\left.\mathrm{CHCl}_{3}\right) ;{ }^{1} \mathrm{H}$ NMR (500 MHz) $\delta$ 7.40-7.25 (5H, br m), 5.83 (1H, ddt, $J=17,10,7 \mathrm{~Hz}), 5.10-5.00$ (2H, br m), 4.34 (1H, dd, $J=10,2.6$ Hz), 4.09 (1H, m), 3.21 (3H, s), 2.30-2.25 (2H, m), 1.88 (1H, ddd, $J=14,10,2.8 \mathrm{~Hz}$ ), 1.62 (1H, ddd, $J$ =14, 9.5, $3 \mathrm{~Hz}$ ), 0.98 (9H, s), 0.17 (3H, s), 0.13 (3H, s); ${ }^{13} \mathrm{C}$ NMR (125 MHz) $\delta 142.8,18.2$ (C), 134.6, 128.5 (x 2), 127.4, 126.5 (x 2), 80.2, 68.3 (CH), 117.1, 46.2, $42.7\left(\mathrm{CH}_{2}\right), 56.4,26.0$ (x 3), -4.1, -4.7 $\left(\mathrm{CH}_{3}\right)$. HR ESMS m/z (\% rel. int.) $343.2065\left(\mathrm{M}+\mathrm{Na}^{+}\right)$. Calcd. for $\mathrm{C}_{19} \mathrm{H}_{32} \mathrm{NaO}_{2} \mathrm{Si}, 343.2069$.

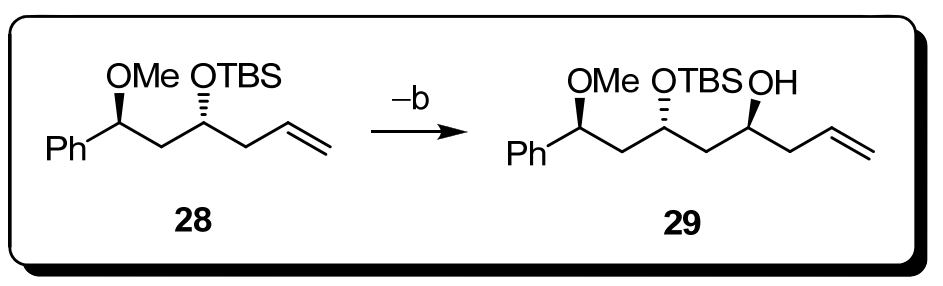

(4S,6R,8S)-6-(Tert-butyldimethylsilyloxy)-8-methoxy-8-phenyloct-1-en-4-ol (29). Prepared in two steps from 28 (via a non isolated intermediate aldehyde) in $75 \%$ overall yield according to experimental conditions $-b$ (pag. S-2). After careful chromatographic purification on silica gel (hexanes-EtOAc 95:5), 29 was isolated as a pure compound: oil; $[\alpha]_{\mathrm{D}}-33.7$ (c 1.1; $\mathrm{CHCl}_{3}$ ); IR $v_{\max }$ 3500 (br, OH) cm ${ }^{-1}$; ${ }^{1} \mathrm{H}$ NMR (500 MHz) $\delta$ 7.40-7.25 (5H, br m), 5.83 (1H, ddt, $J=17,10,7 \mathrm{~Hz}$ ), 5.155.05 (2H, br m), 4.30-4.20 (2H, m), 4.00 (1H, m), 3.20 (3H, s), 2.30-2.15 (2H, m), 1.95-1.90 (2H, m), 1.74 (1H, ddd, $J=14,10.2,4.4 \mathrm{~Hz}), 1.61$ (1H, ddd, $J=14,4,2.5 \mathrm{~Hz}), 0.96(9 \mathrm{H}, \mathrm{s}), 0.14(6 \mathrm{H}, \mathrm{s}) ;{ }^{13} \mathrm{C}$ NMR (125 MHz) $\delta$ 142.1, 18.0 (C), 134.9, 128.5 (x 2), 127.6, 126.5 (x 2), 80.3, 68.8, 68.0 (CH), 117.1, 45.5, 42.3, $42.1\left(\mathrm{CH}_{2}\right)$, 56.3, 25.9 (x 3), -4.3, -5.0 $\left(\mathrm{CH}_{3}\right)$. HR ESMS m/z (\% rel. int.) 387.2328 $\left(\mathrm{M}+\mathrm{Na}^{+}\right)$. Calcd. for $\mathrm{C}_{21} \mathrm{H}_{36} \mathrm{NaO}_{3} \mathrm{Si}, 387.2331$. 


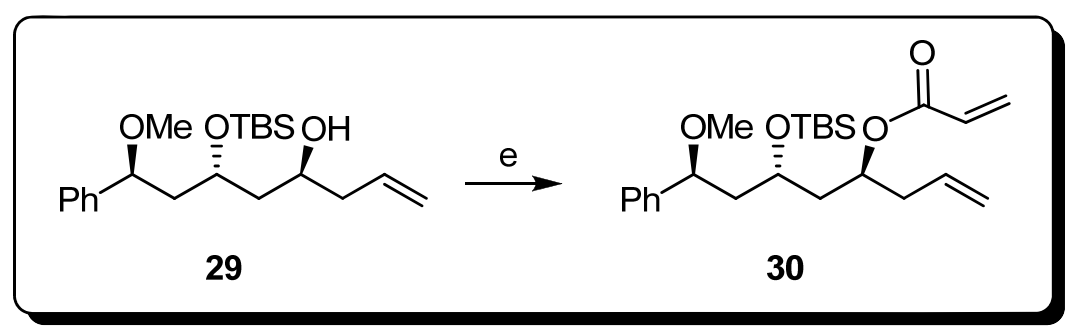

(4S,6R,8S)-6-(Tert-butyldimethylsilyloxy)-8-methoxy-8-phenyloct-1-en-4-yl acrylate (30). Prepared from 29 in 78\% yield according to experimental conditions $e$ (pag. S-3): oil; $[\alpha]_{\mathrm{D}}-9.7$ (c 1.2; $\mathrm{CHCl}_{3}$ ); IR $v_{\max } 1725(\mathrm{C}=\mathrm{O}) \mathrm{cm}^{-1} ;{ }^{1} \mathrm{H}$ NMR (500 MHz) $\delta$ 7.40-7.25 (5H, br m), 6.35 (1H, dd, $\left.J=17,1.5 \mathrm{~Hz}\right)$, 6.08 (1H, dd, $J=17,10.3 \mathrm{~Hz}$ ), 5.80-5.70 (2H, m), 5.15-5.00 (3H, br m), 4.24 (1H, dd, $J=8.3,5 \mathrm{~Hz}$ ), 3.87 (1H, m), 3.19 (3H, s), 2.45-2.35 (2H, m), 1.96 (1H, ddd, $J=14,8.5,5.3 \mathrm{~Hz}), 1.84$ (1H, ddd, $J=14$, 8.2, $4.5 \mathrm{~Hz}), 1.80-1.70$ (2H, m), $0.92(9 \mathrm{H}), 0.04$ (3H, s), 0.00 (3H, s); ${ }^{13} \mathrm{C}$ NMR (125 MHz) $\delta 165.6$, 142.3, 18.1 (C), 133.4, 129.0, 128.5 (x 2), 127.6, 126.7 (x 2), 80.5, 71.1, 66.4 (CH), 130.2, 118.0, 46.9, 41.9, $39.0\left(\mathrm{CH}_{2}\right)$, 56.3, 26.0 (x 3), -4.5, -4.6 ( $\left.\mathrm{CH}_{3}\right)$; HR ESMS m/z (\% rel. int.) $441.2437\left(\mathrm{M}^{+} \mathrm{Na}^{+}\right)$. Calcd. for $\mathrm{C}_{24} \mathrm{H}_{38} \mathrm{NaO}_{4} \mathrm{Si}, 441.2437$.

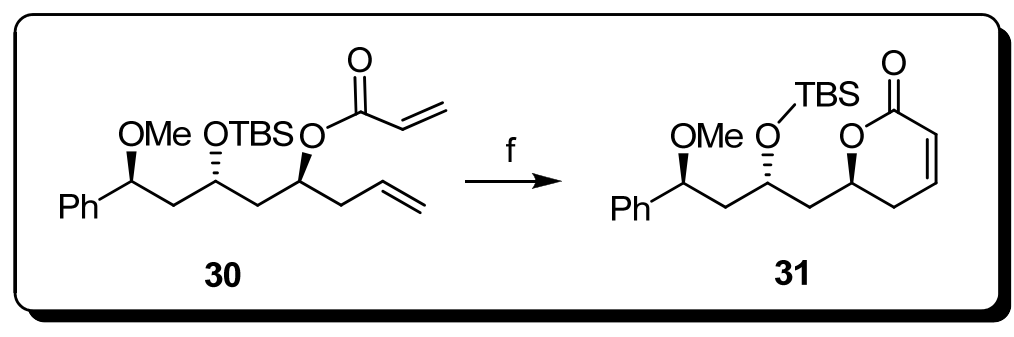

(6S)-6-[(2R,4S)-2-(Tert-butyldimethylsilyloxy)-4-methoxy-4-phenylbutyl]-5,6-dihydro-2H-pyran-

2-one (31). Prepared from 30 in 80\% yield according to experimental conditions $f$ (pag. S-3): oil; $[\alpha]_{D}$ -54.9 (c 1, $\left.\mathrm{CHCl}_{3}\right)$; IR $v_{\max } 1713(\mathrm{C}=\mathrm{O}) \mathrm{cm}^{-1}$; ${ }^{1} \mathrm{H}$ NMR (500 MHz) $\delta$ 7.40-7.25 (5H, br m), $6.88(1 \mathrm{H}$, dt, $J=9.8,4.3 \mathrm{~Hz}), 6.02(1 \mathrm{H}, \mathrm{br} \mathrm{d}, J=9.8 \mathrm{~Hz}), 4.59(1 \mathrm{H}, \mathrm{m}), 4.24(1 \mathrm{H}, \mathrm{dd}, J=8.8,4 \mathrm{~Hz}), 4.18(1 \mathrm{H}$, m), 3.17 (3H, s), 2.40-2.30 (2H, m), 2.06 (1H, ddd, $J=14,8.8,4$ Hz), 1.92 (1H, ddd, $J=14,8.8,5.5$ Hz), 1.76 (1H, ddd, $J=14,6.4,4.4 \mathrm{~Hz}$ ), 1.67 (1H, ddd, $J=14,8.8,4 \mathrm{~Hz}$ ), 0.91 (9H, s), 0.10 (3H, s), 0.06 (3H, s); ${ }^{13} \mathrm{C}$ NMR (125 MHz) $\delta$ 164.2, 142.2, 18.0 (C), 145.0, 128.5 (x 2), 127.7, 126.5 (x 2), 121.5, 80.5, 74.6, 65.7 (CH), 47.5, 43.4, $30.0\left(\mathrm{CH}_{2}\right)$, 56.3, 25.9 (x 3), -4.4, -4.5 $\left(\mathrm{CH}_{3}\right)$; HR ESMS m/z (\% rel. int.) $413.2120\left(\mathrm{M}+\mathrm{Na}^{+}\right)$. Calcd. for $\mathrm{C}_{22} \mathrm{H}_{34} \mathrm{NaO}_{4} \mathrm{Si}, 413.2124$. 


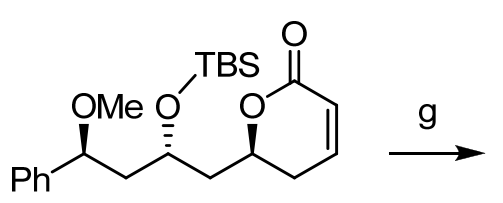

31<smiles>CO[C@H](C[C@@H]1CC=CC(=O)O1)c1ccccc1</smiles>

6

(6S)-6-[(2R,4S)-2-Hydroxy-4-methoxy-4-phenylbutyl]-5,6-dihydro-2H-pyran-2-one (6). Prepared from 31 in 90\% yield according to experimental conditions $g$ (pag. S-3): oil; $[\alpha]_{\mathrm{D}}-119.1$ (c 1, $\mathrm{CHCl}_{3}$ ); IR $v_{\max } 3440$ (br, OH), $1713(\mathrm{C}=\mathrm{O}) \mathrm{cm}^{-1} ;{ }^{1} \mathrm{H}$ NMR (500 MHz) $\delta$ 7.40-7.25 (5H, br m), $6.88(1 \mathrm{H}, \mathrm{dt}, J$ = 9.6, $4 \mathrm{~Hz}), 6.02(1 \mathrm{H}$, br d, $J=9.6 \mathrm{~Hz}), 4.73(1 \mathrm{H}, \mathrm{m}), 4.49(1 \mathrm{H}, \mathrm{dd}, J=8.8,3 \mathrm{~Hz}), 4.23(1 \mathrm{H}, \mathrm{m}), 3.23$ (3H, s), 3.00 (1H, br s, OH), 2.45-2.35 (2H, m), 2.00-1.90 (2H, br m), 1.85-1.70 (2H, m); ${ }^{13} \mathrm{C}$ NMR (125 MHz) $\delta$ 164.3, 141.4 (C), 145.3, 128.5 (x 2), 127.7, 126.3 (x 2), 121.3, 81.1, 75.2, 64.6 (CH), 45.1, 42.4, $30.0\left(\mathrm{CH}_{2}\right)$, $56.7\left(\mathrm{CH}_{3}\right)$; HR ESMS m/z (\% rel. int.) $299.1260\left(\mathrm{M}+\mathrm{Na}^{+}\right)$. Calcd. for $\mathrm{C}_{16} \mathrm{H}_{20} \mathrm{NaO}_{4}, 299.1259$. 


\section{Synthesis and biological evaluation of pironetin analogues with enhanced lipophilicity}

Miguel Carda, $^{\dagger}$ Juan Murga, ${ }^{\dagger}$ Eva Falomir, ${ }^{\dagger}$ Santiago Díaz-Oltra, ${ }^{\dagger}$ Jorge García-Pla, ${ }^{\dagger}$ Julián Paños, ${ }^{\dagger}$ Chiara Trigili, ${ }^{\ddagger}$ J. Fernando Díaz, ${ }^{\ddagger}$ Isabel Barasoain ${ }^{\ddagger}$ and J. Alberto Marco ${ }^{\S}$

$+$

${ }^{\dagger}$ Depart. de Q. Inorgánica y Orgánica, Univ. Jaume I, 12080 Castellón, Spain; ${ }^{\S}$ CIB, CSIC, 28040 Madrid, Spain; and ${ }^{\ddagger}$ Depart. de Q. Orgánica, Univ. de Valencia, 46100 Burjassot, Valencia, Spain

\section{Supporting Information}

Contents:

S-2/S-15: $\quad N M R$ spectra of new intermediate and final compounds 
NMR spectra of intermediate and final compounds

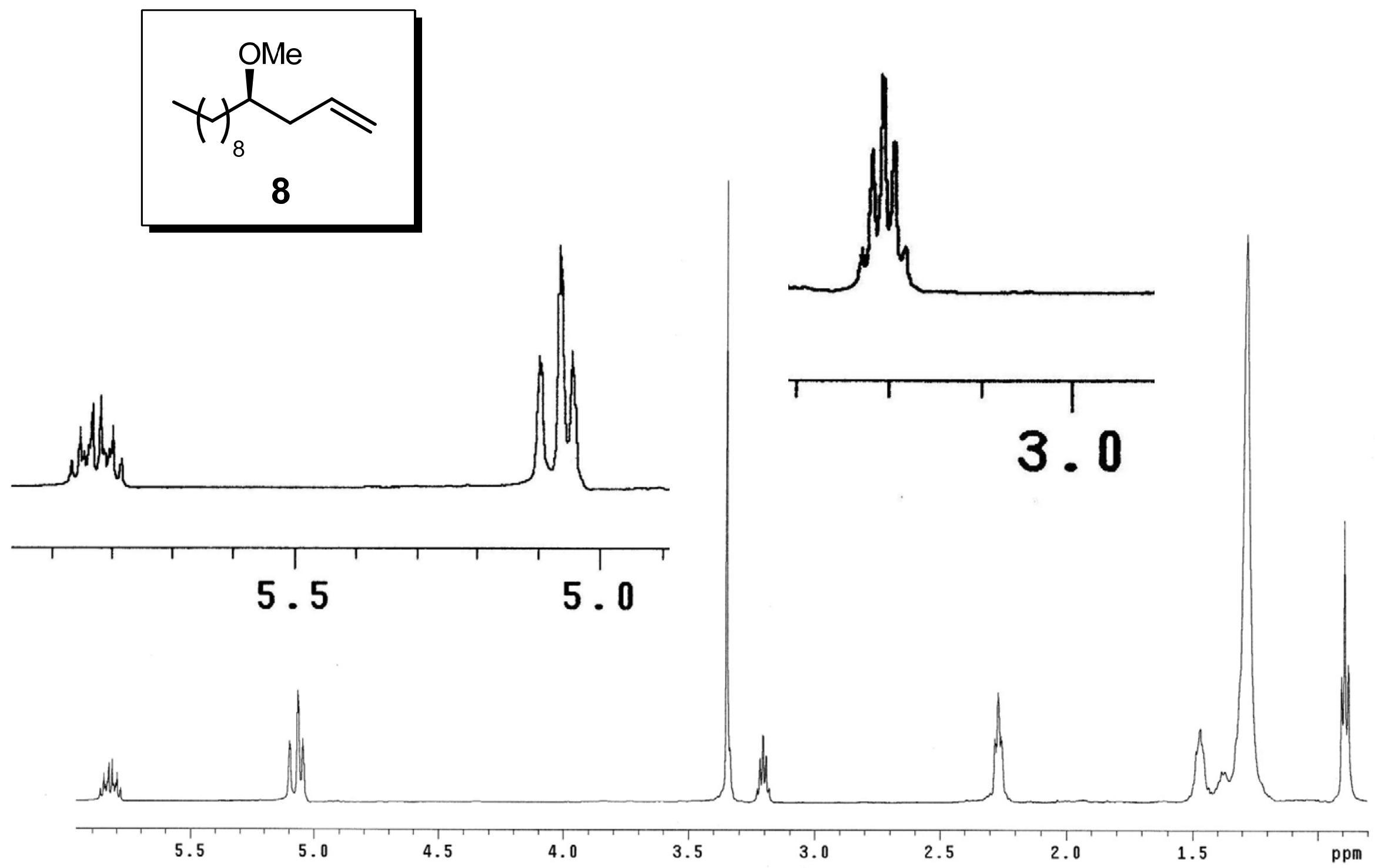




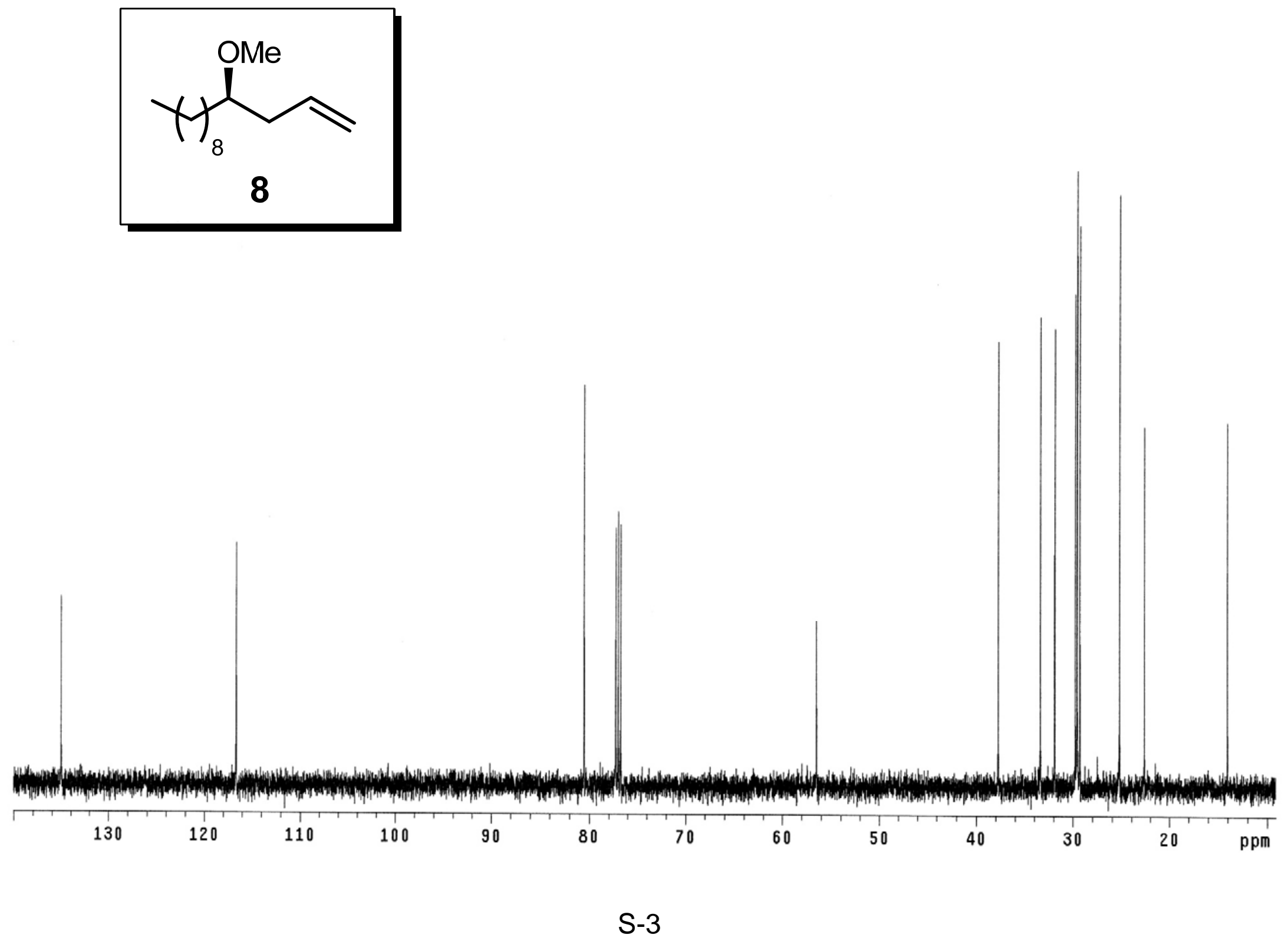




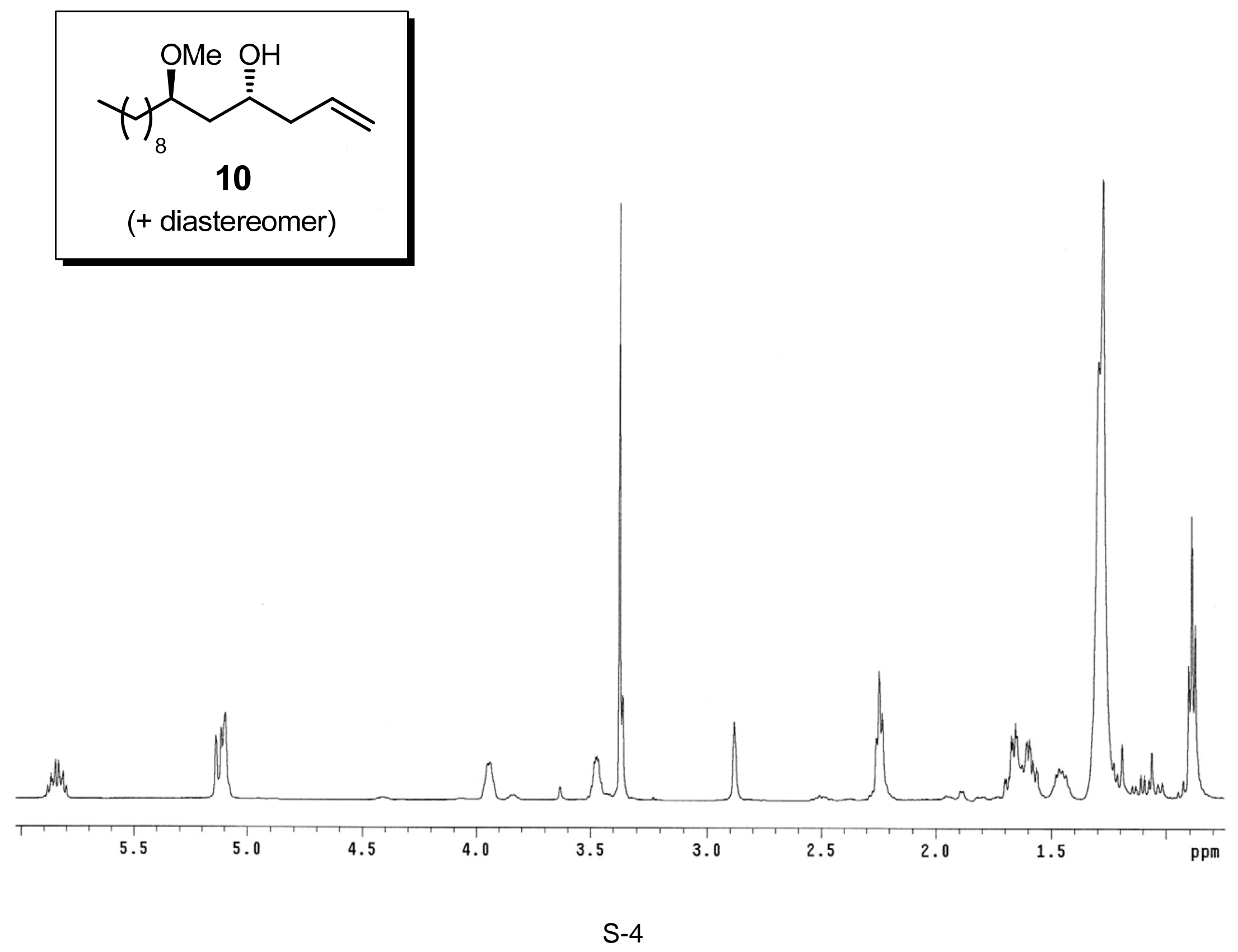



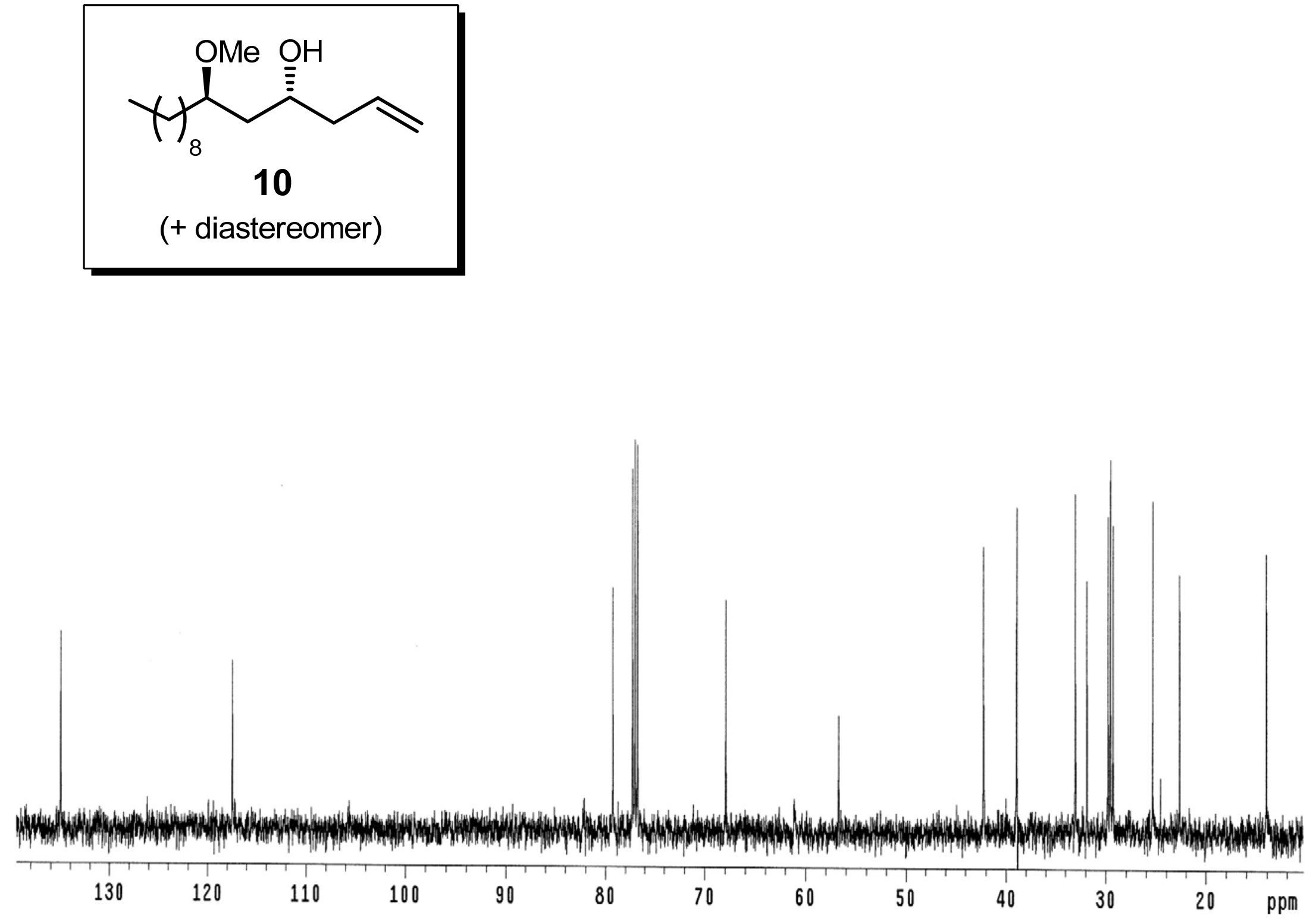

S-5 

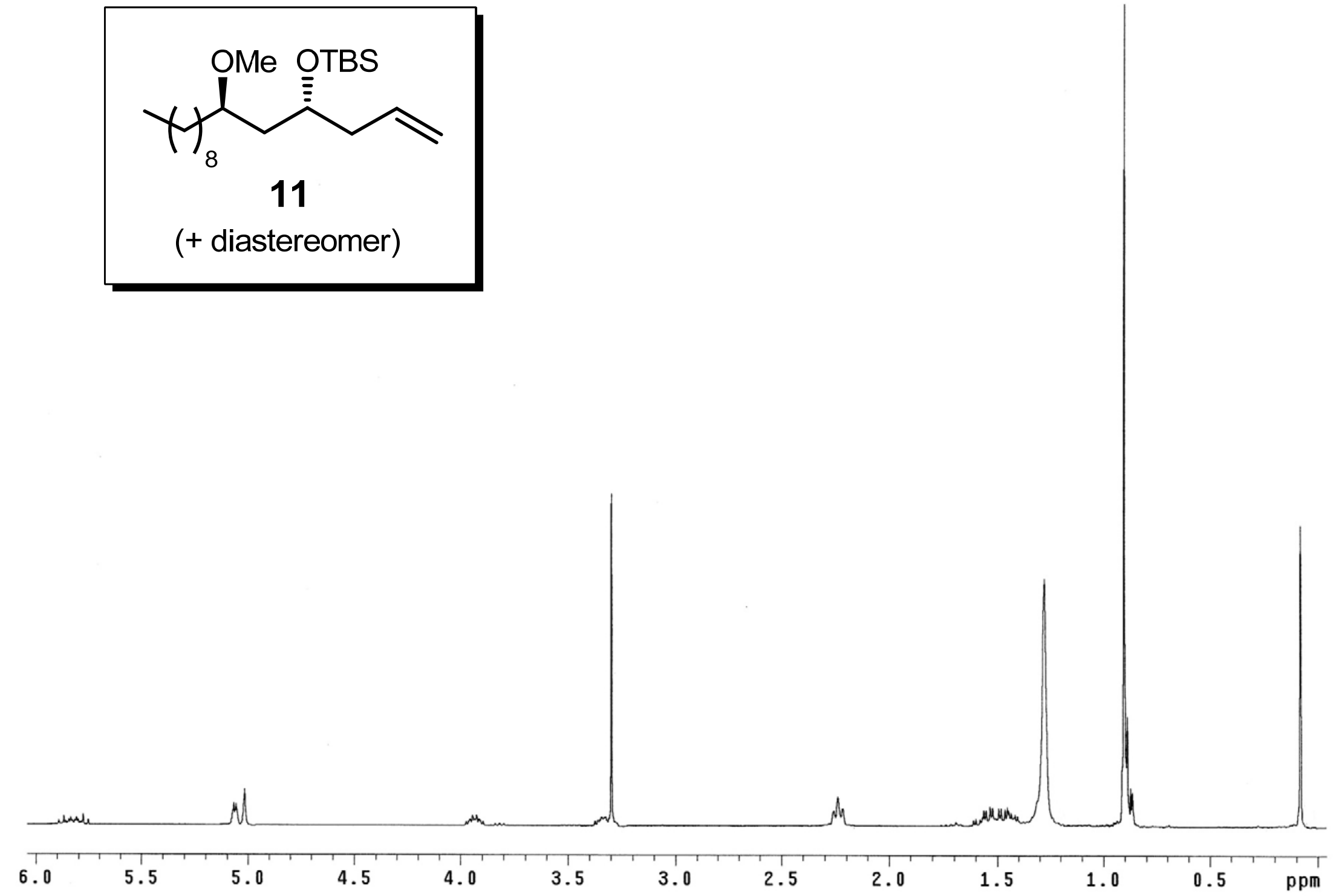







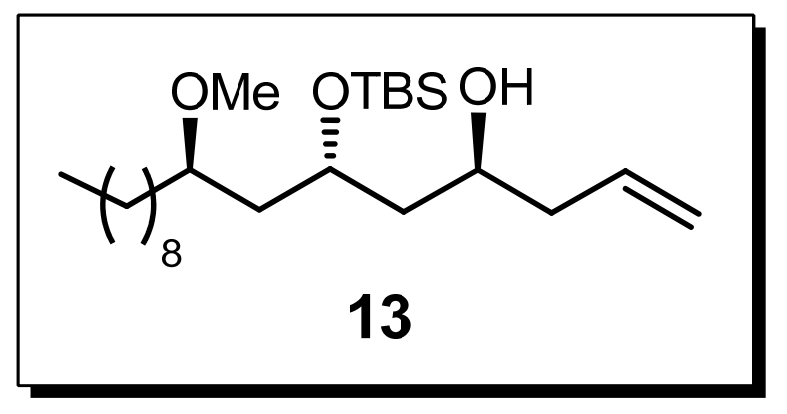

-avtmm


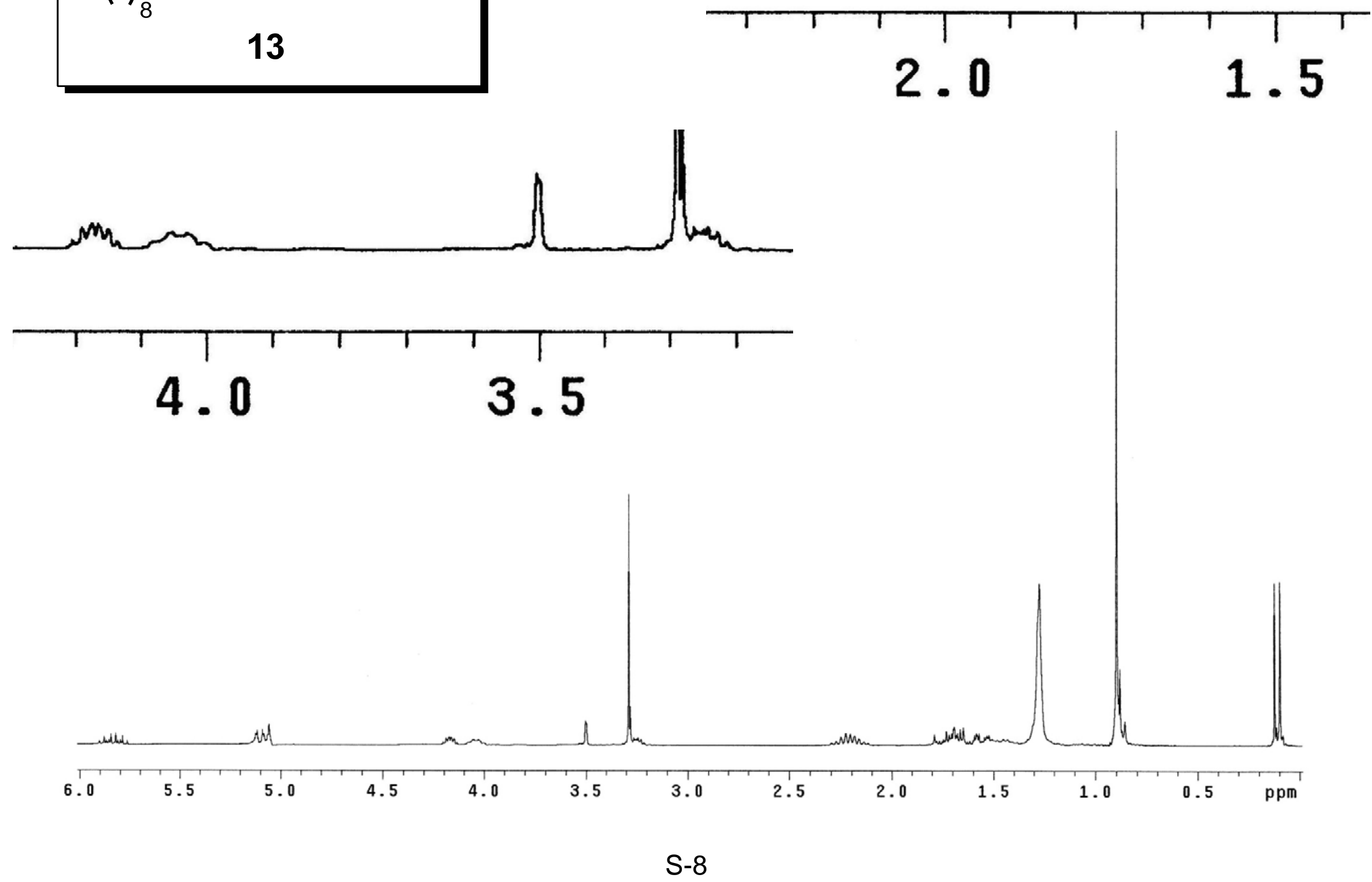


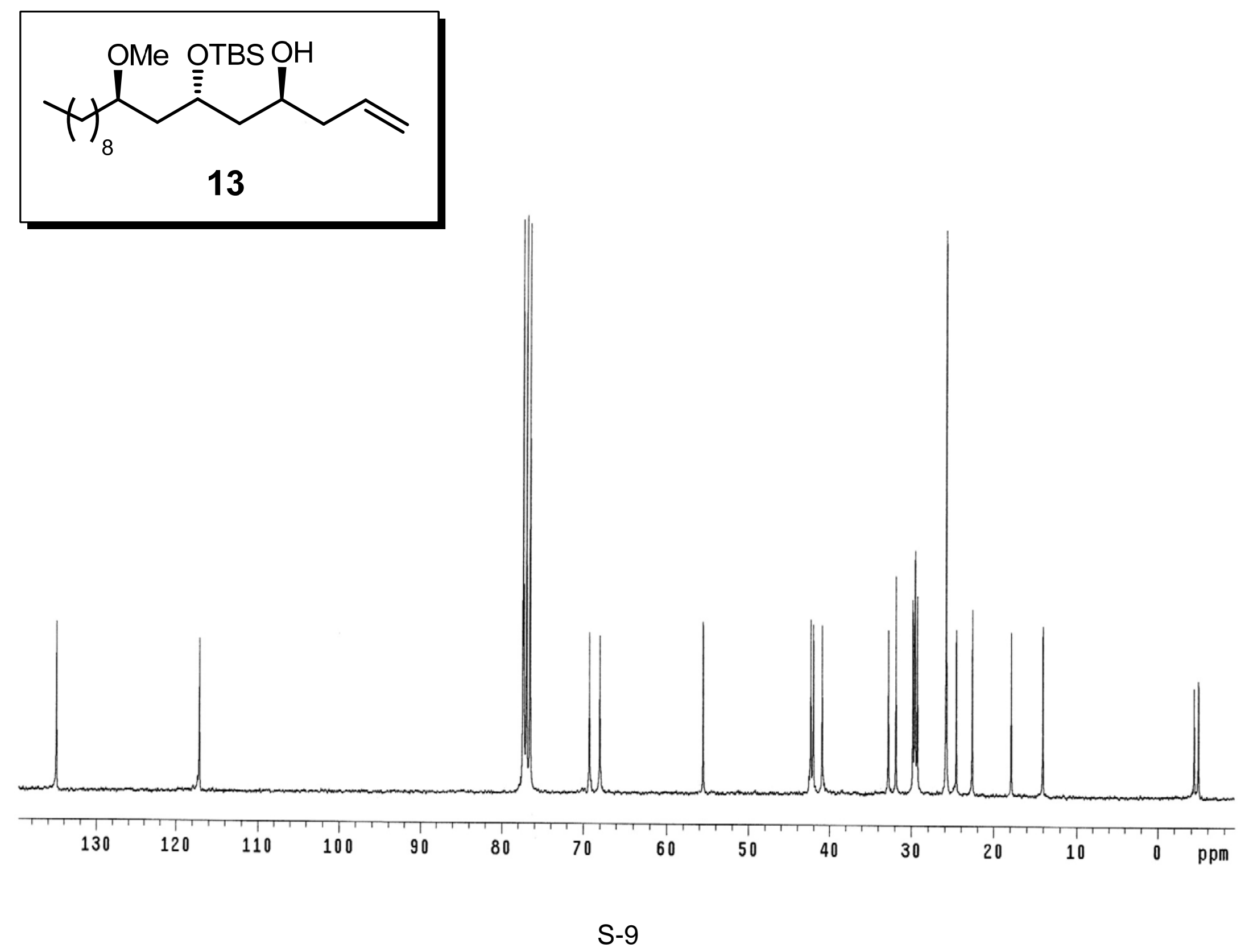




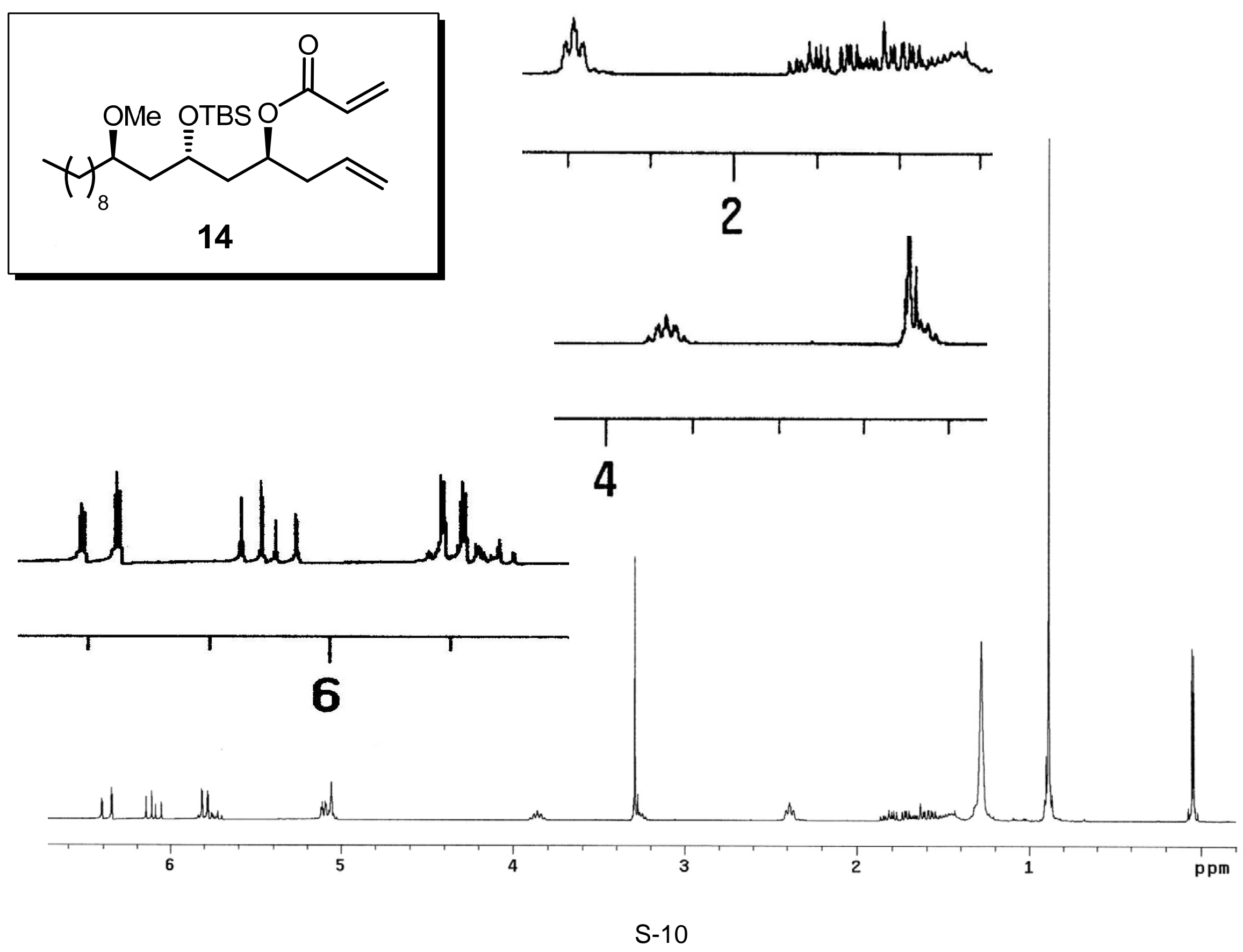




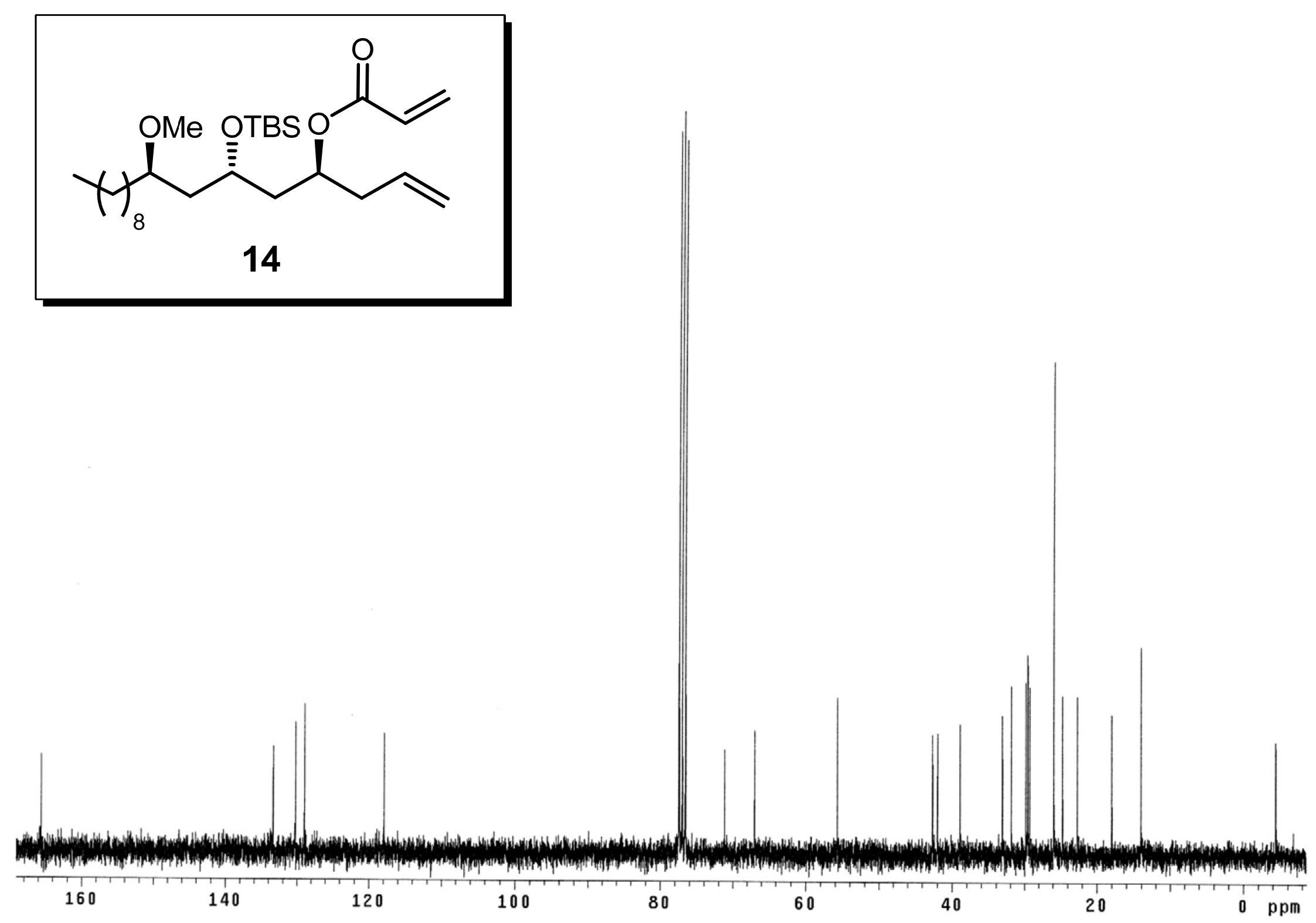

S-11 


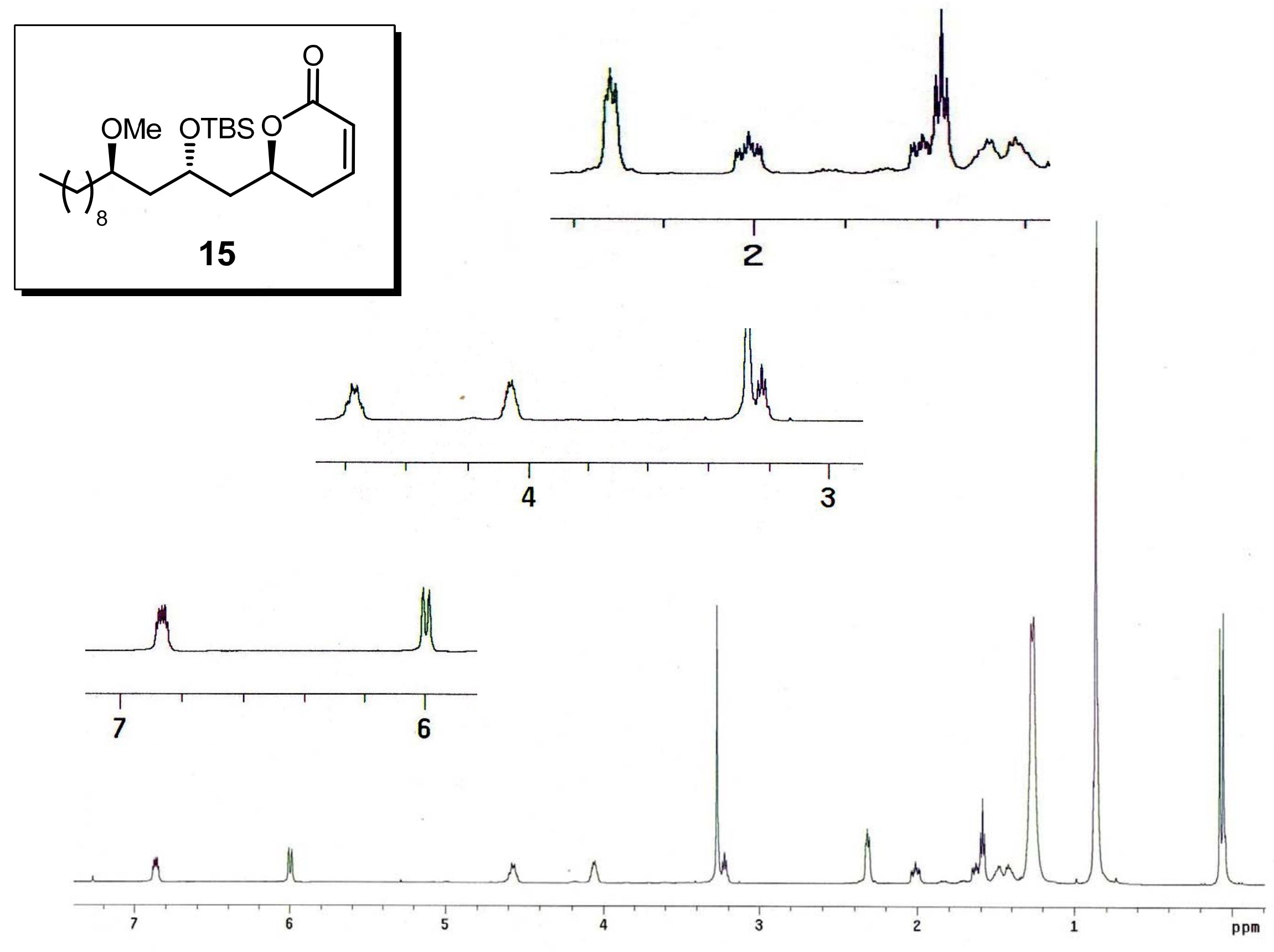

S-12 

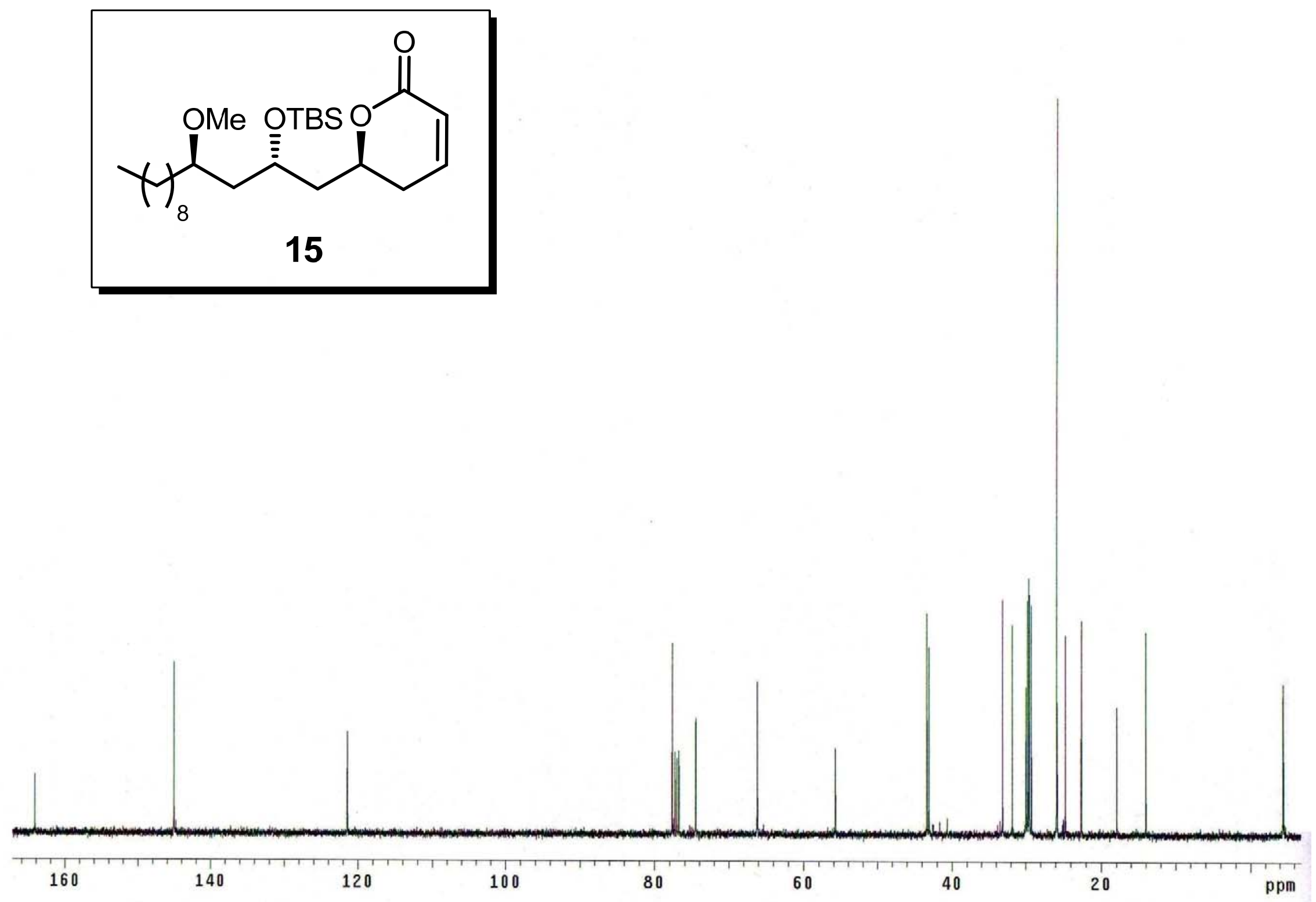

S-13 



S-14 

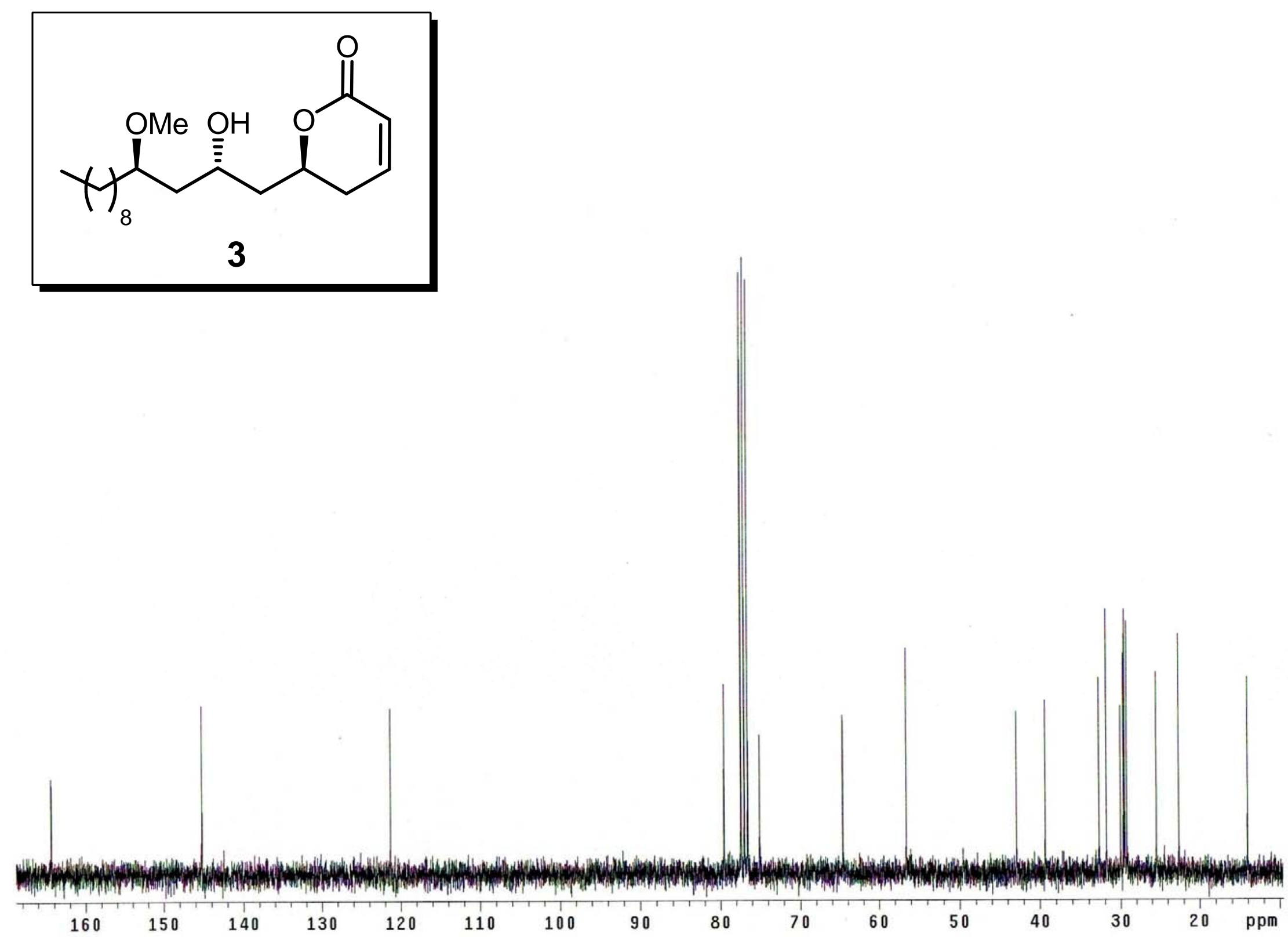

S-15 


\section{Synthesis and biological evaluation of pironetin analogues with enhanced lipophilicity}

Miguel Carda, $^{\dagger}$ Juan Murga, ${ }^{\dagger}$ Eva Falomir, ${ }^{\dagger}$ Santiago Díaz-Oltra, ${ }^{\dagger}$ Jorge García-Pla, ${ }^{\dagger}$ Julián Paños, ${ }^{\dagger}$ Chiara Trigili, ${ }^{\ddagger}$ J. Fernando Díaz, ${ }^{\ddagger}$ Isabel Barasoain ${ }^{\ddagger}$ and J. Alberto Marco ${ }^{\S}$

$+$

${ }^{\dagger}$ Depart. de Q. Inorgánica y Orgánica, Univ. Jaume I, 12080 Castellón, Spain; ${ }^{\S}$ CIB, CSIC, 28040 Madrid, Spain; and ${ }^{\ddagger}$ Depart. de Q. Orgánica, Univ. de Valencia, 46100 Burjassot, Valencia, Spain

\section{Supporting Information}

Contents:

S-2/S-17: $\quad$ NMR spectra of new intermediate and final compounds 
NMR spectra of intermediate and final compovunds
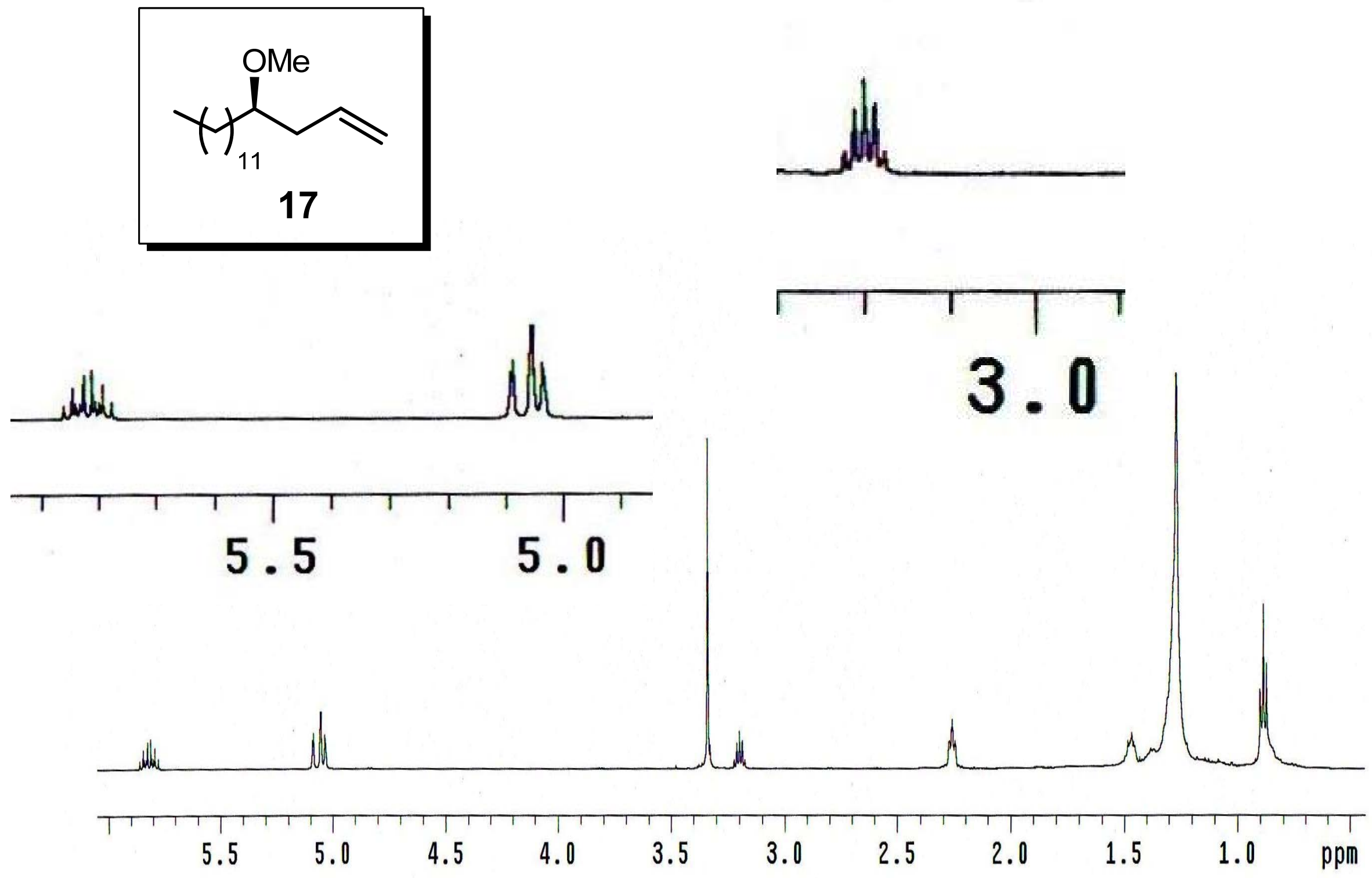

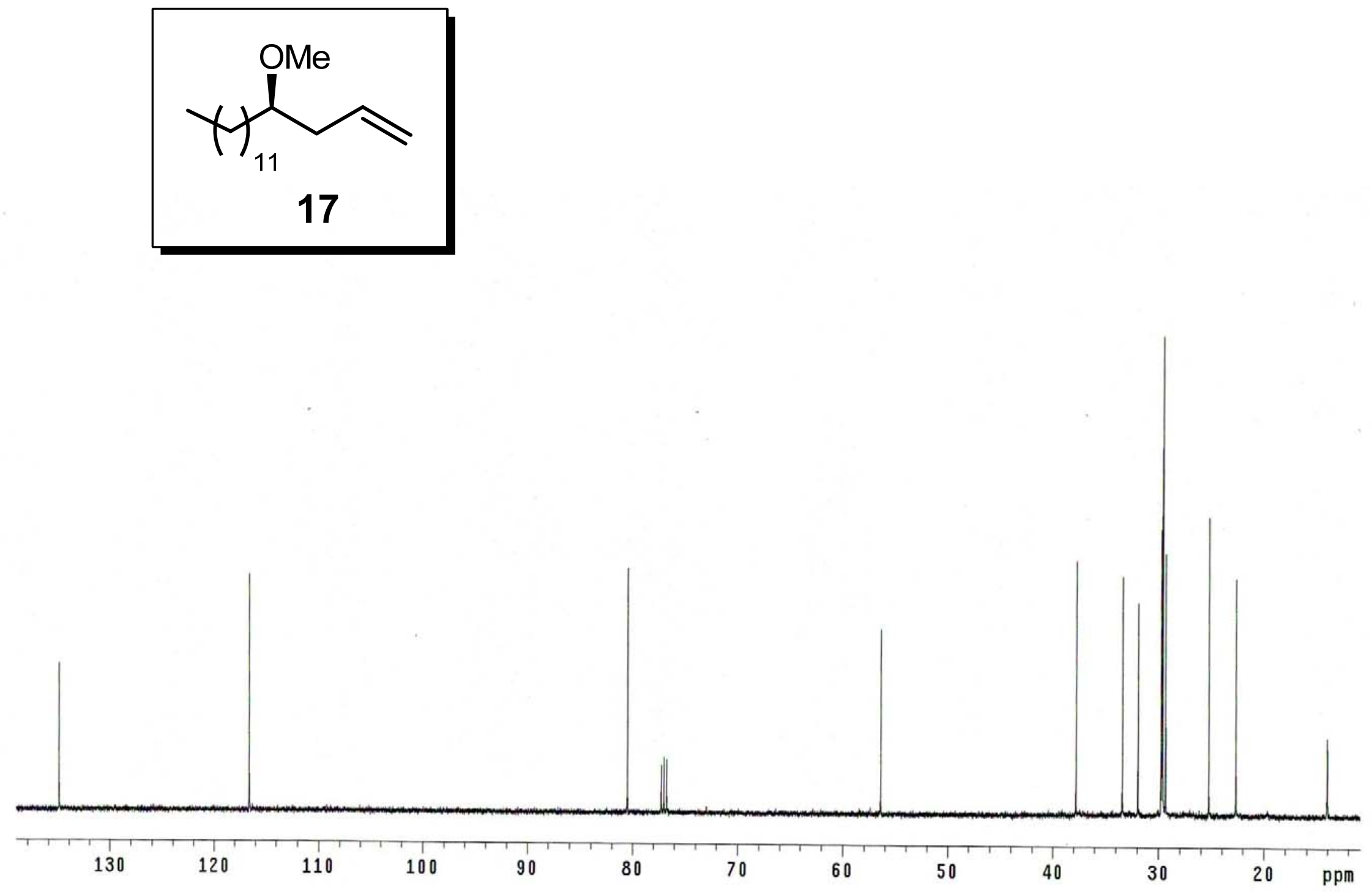

S-3 


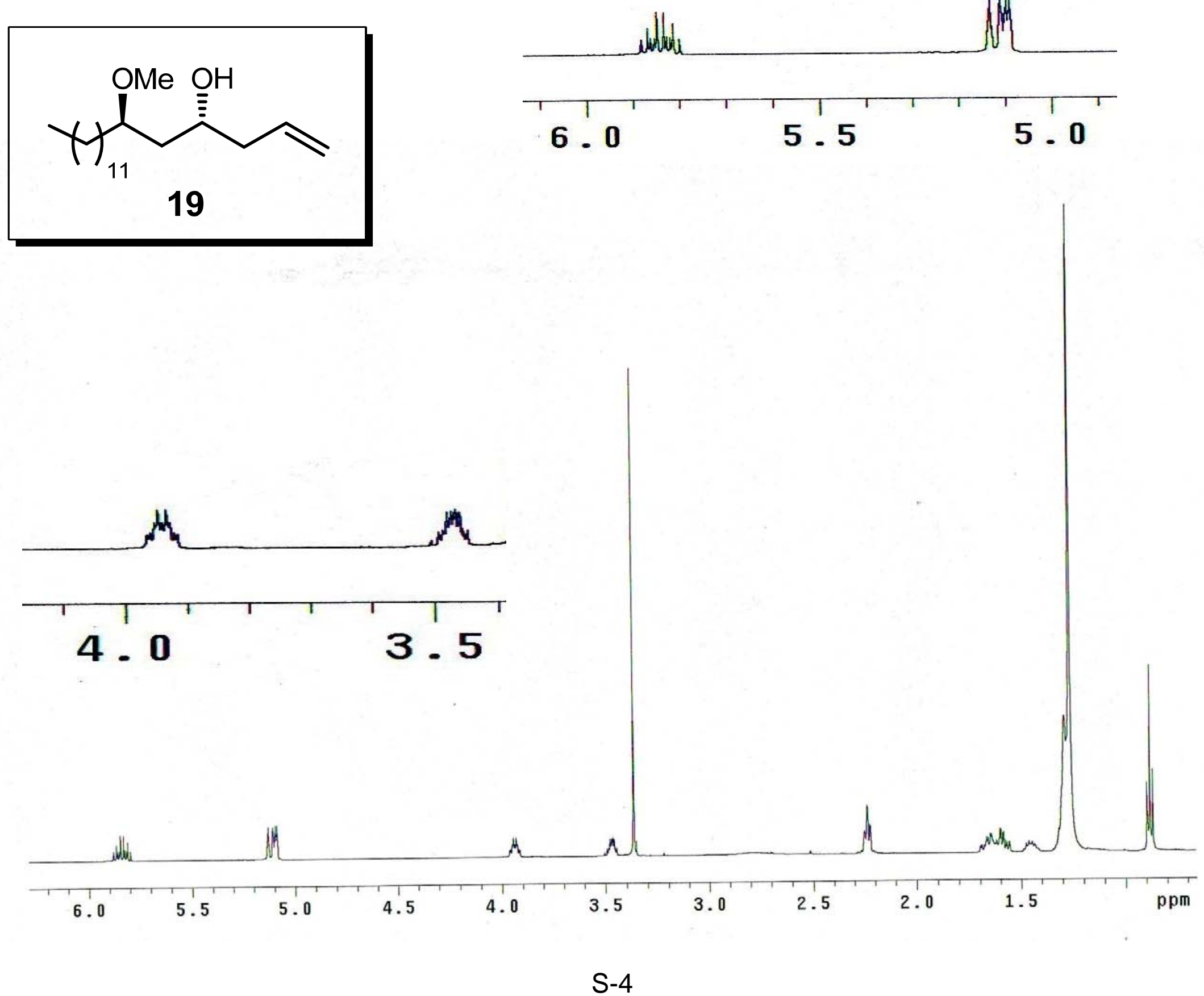




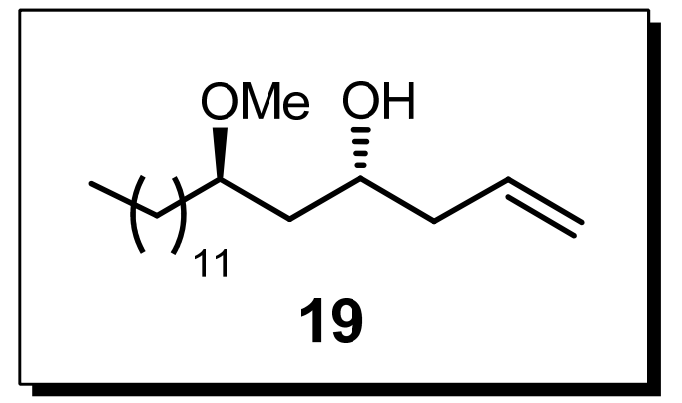

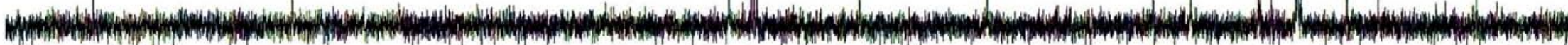

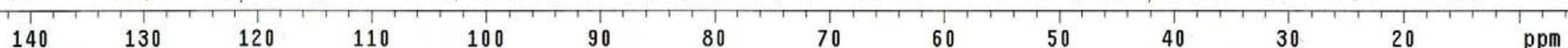



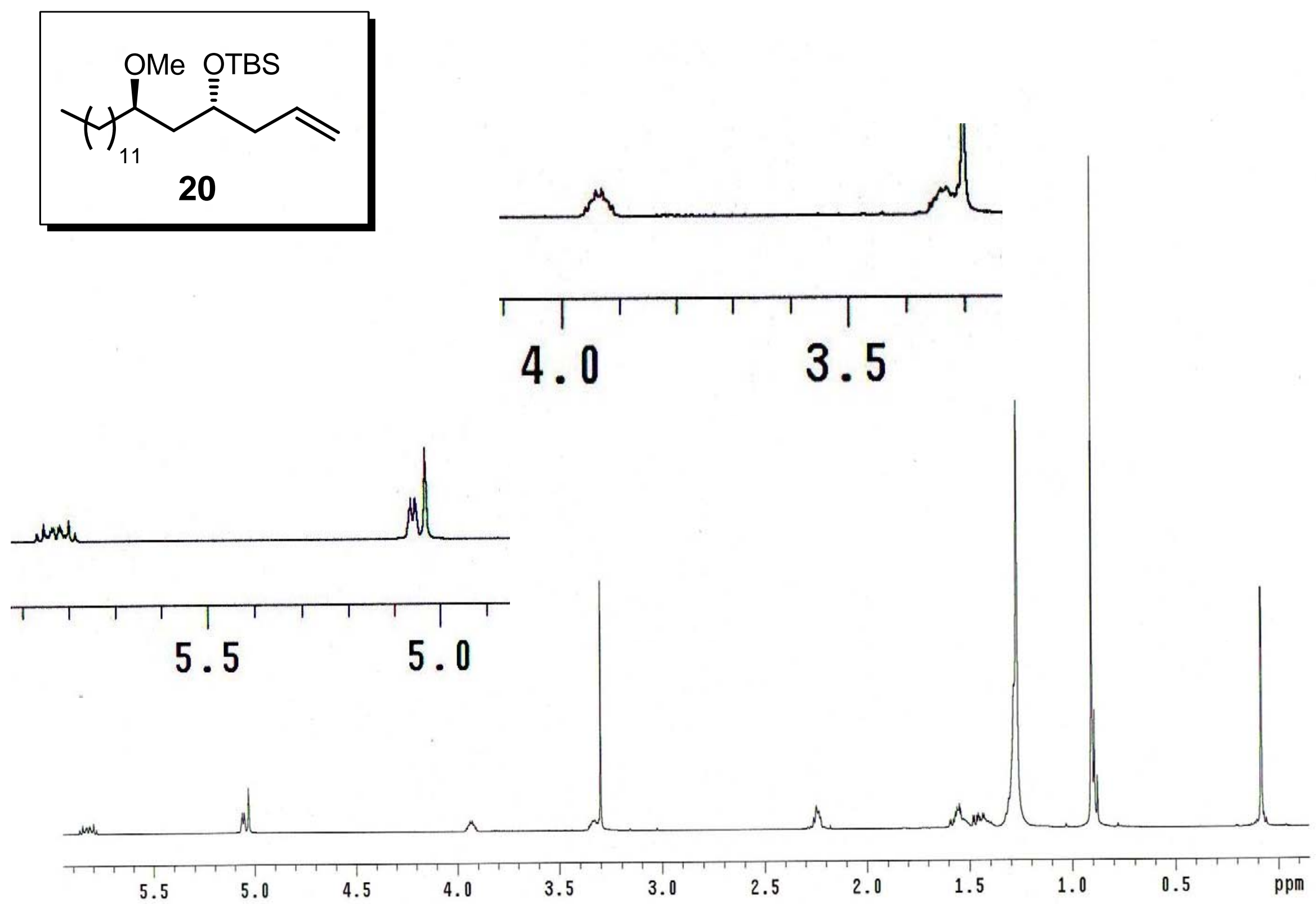

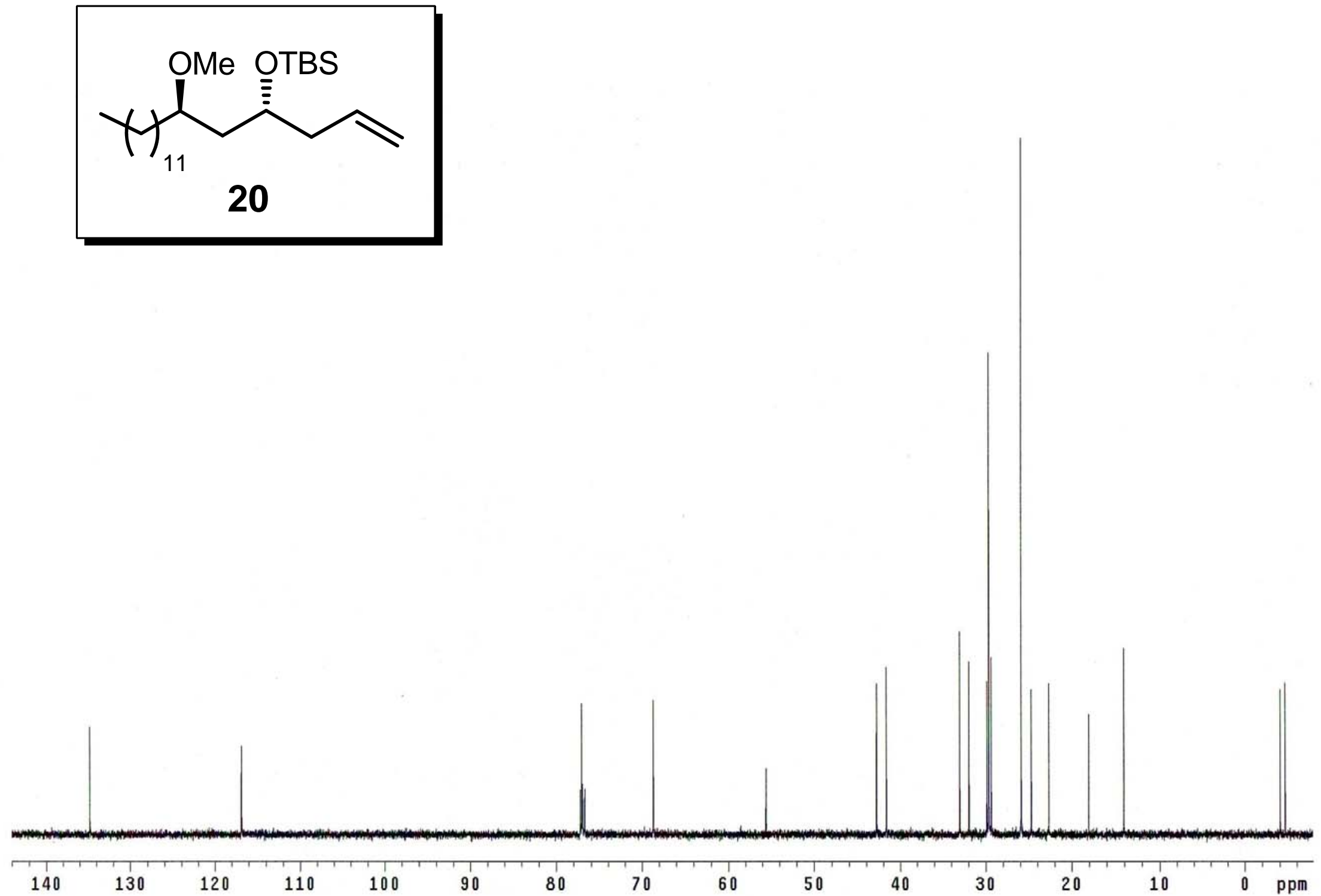


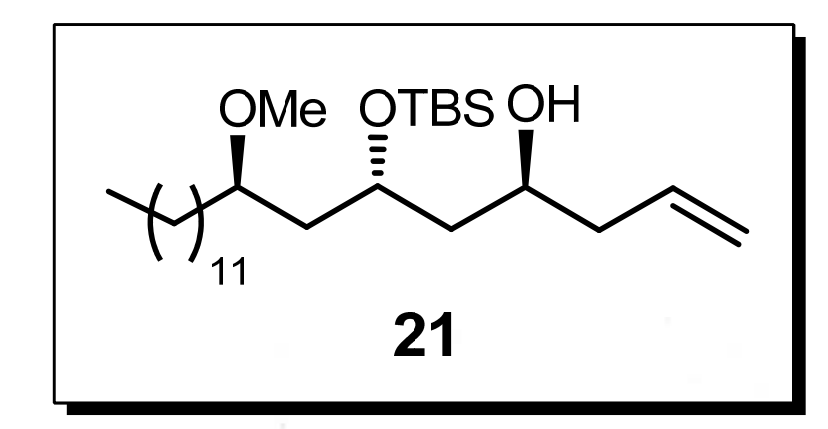

wotholth

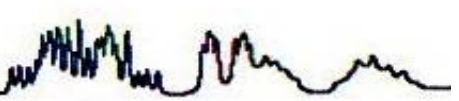
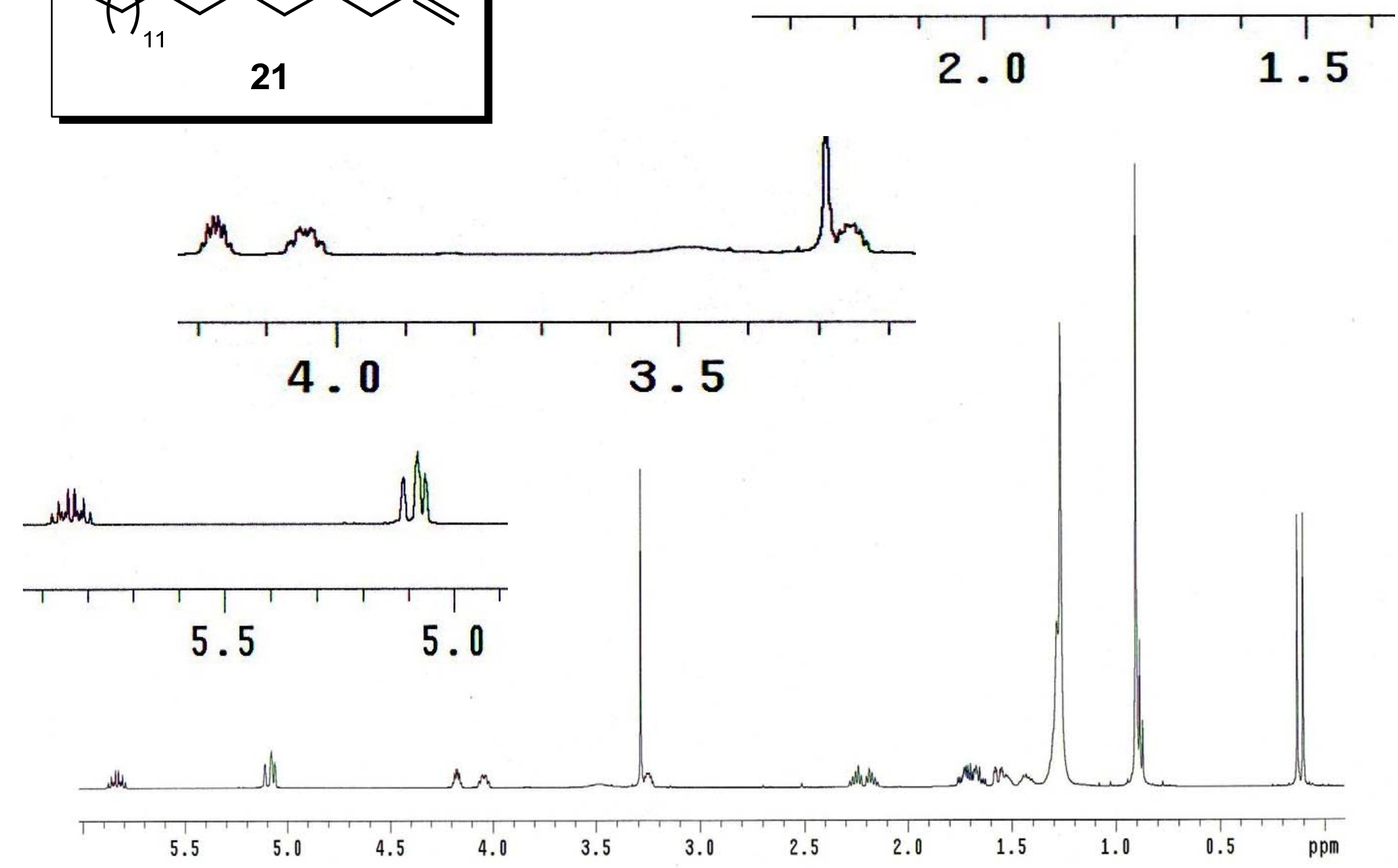

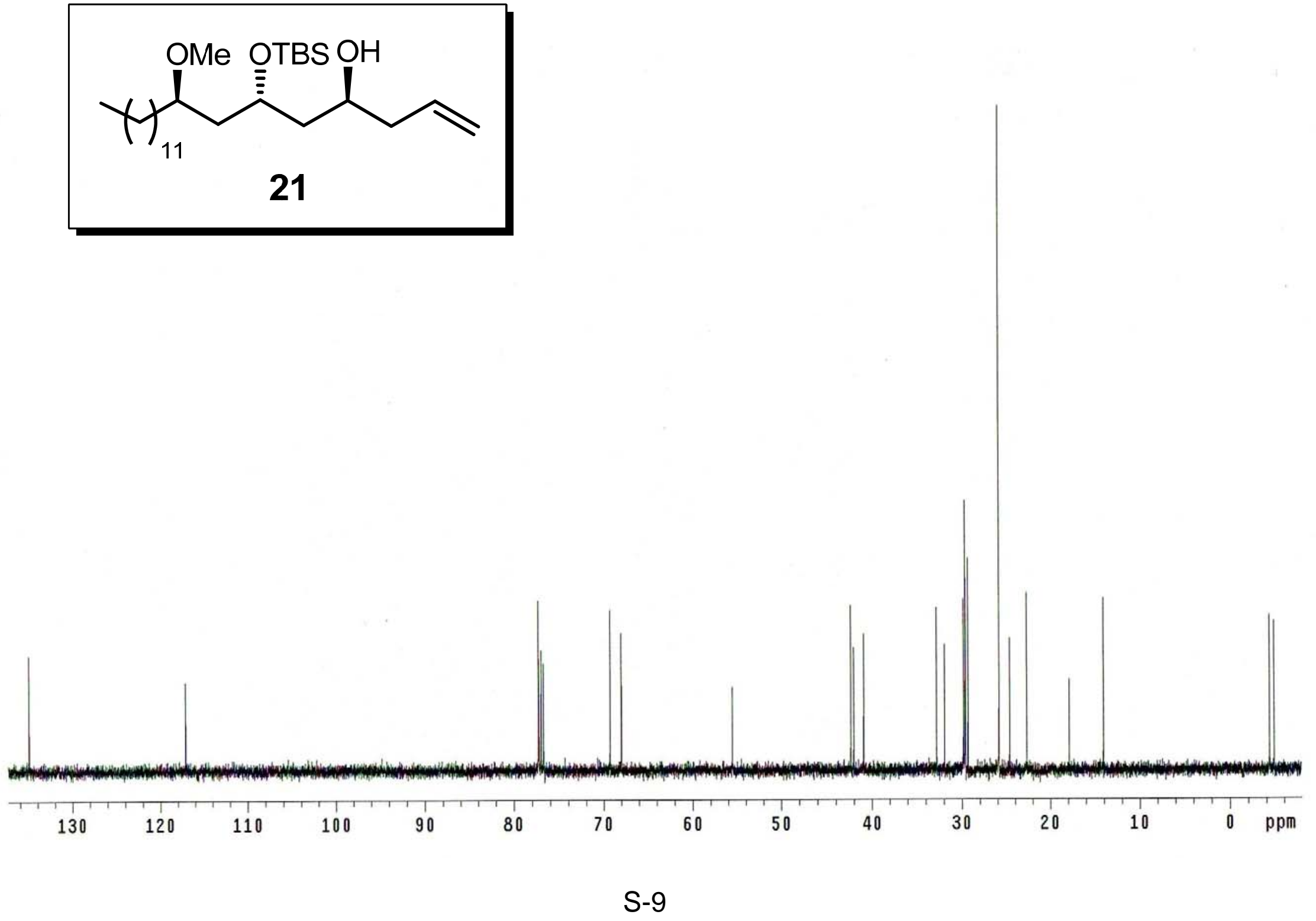

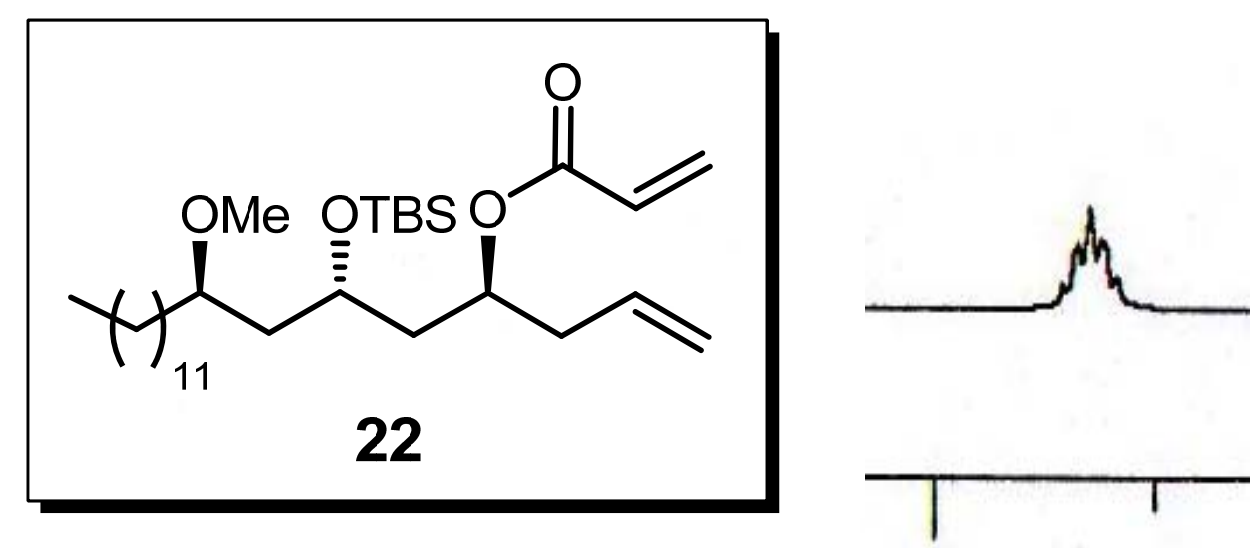

4
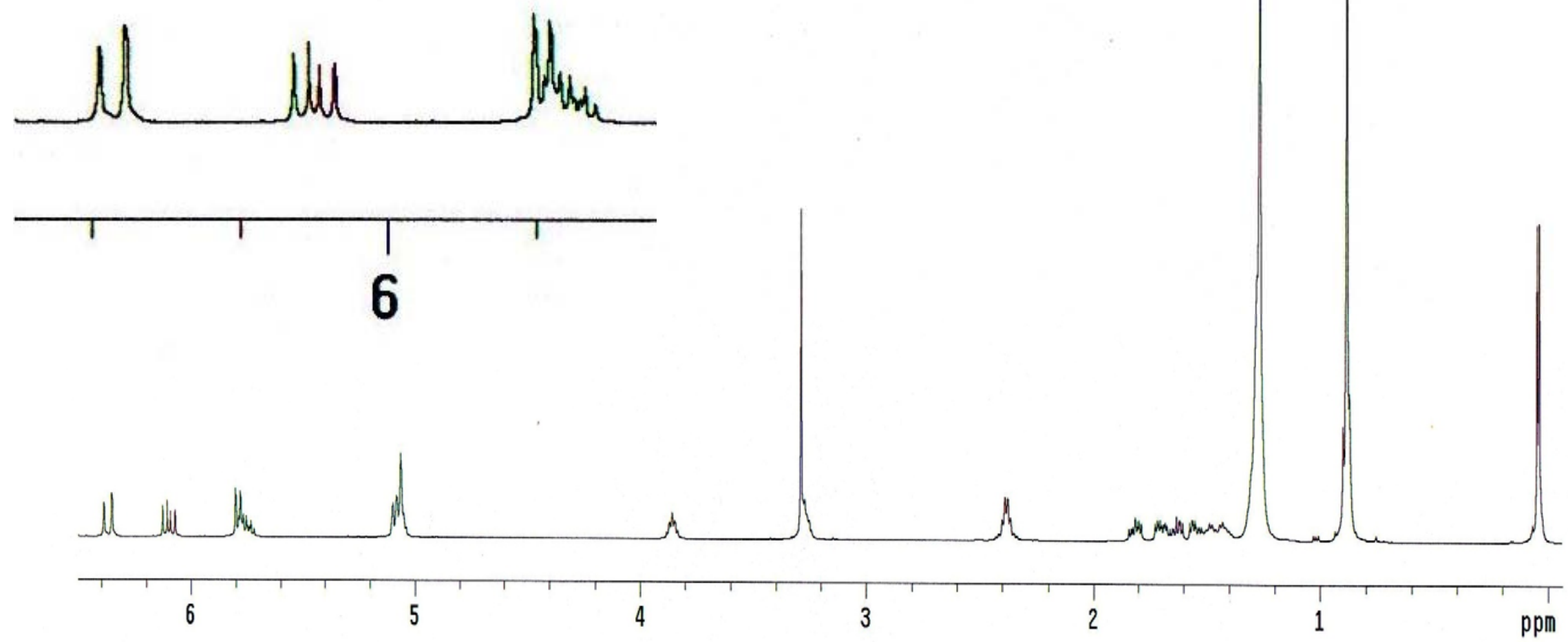


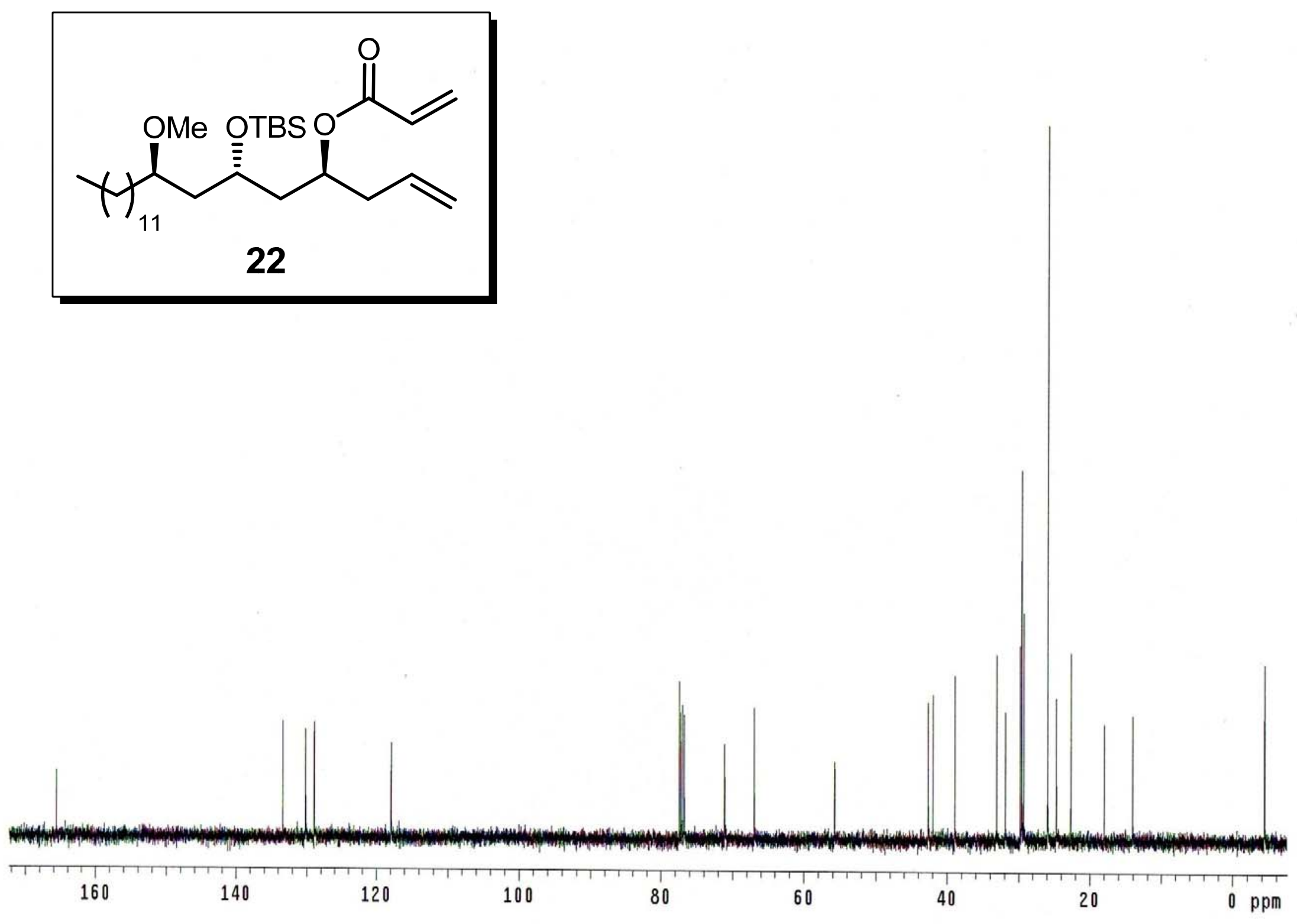

S-11 

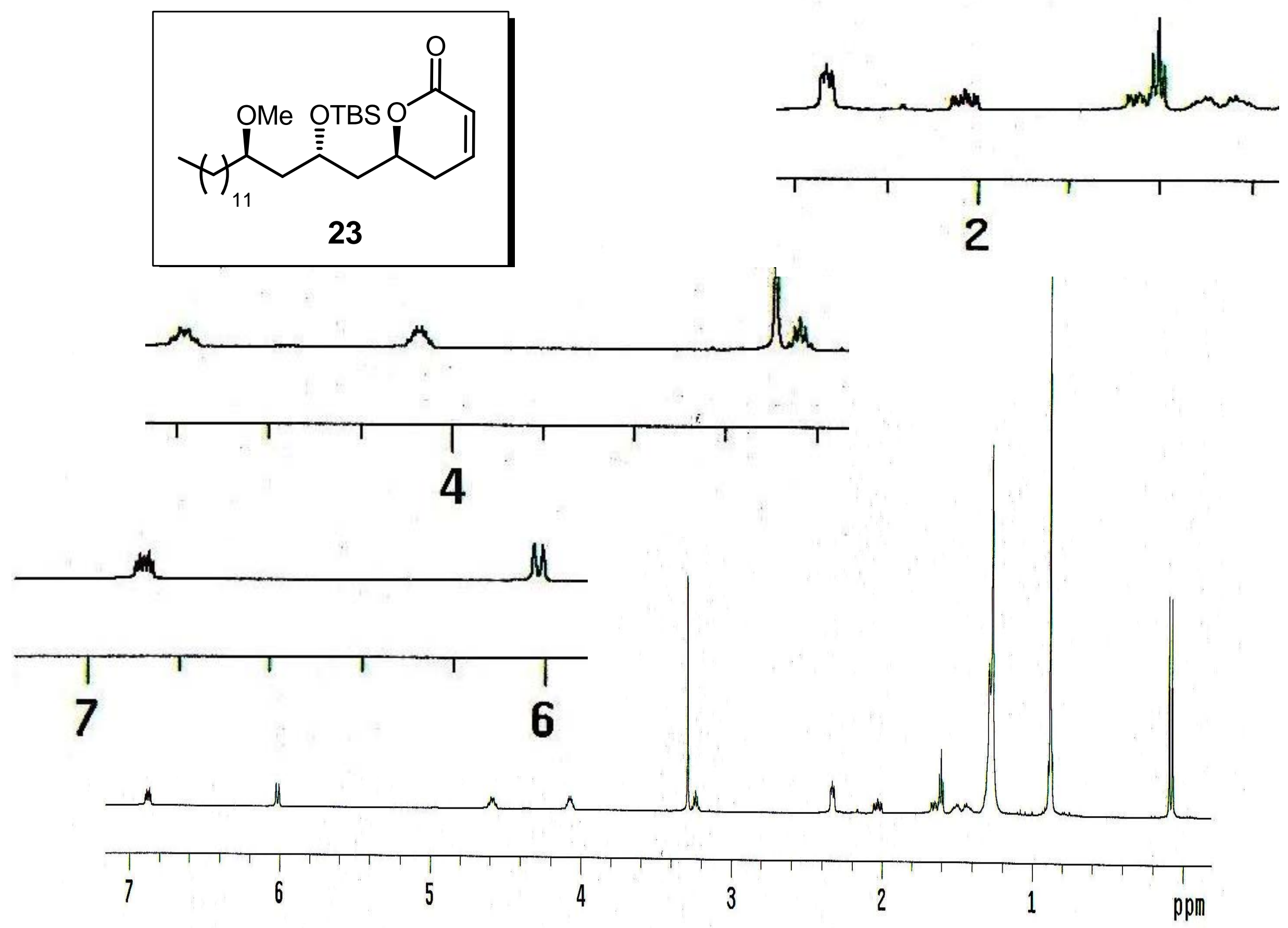

S-12 

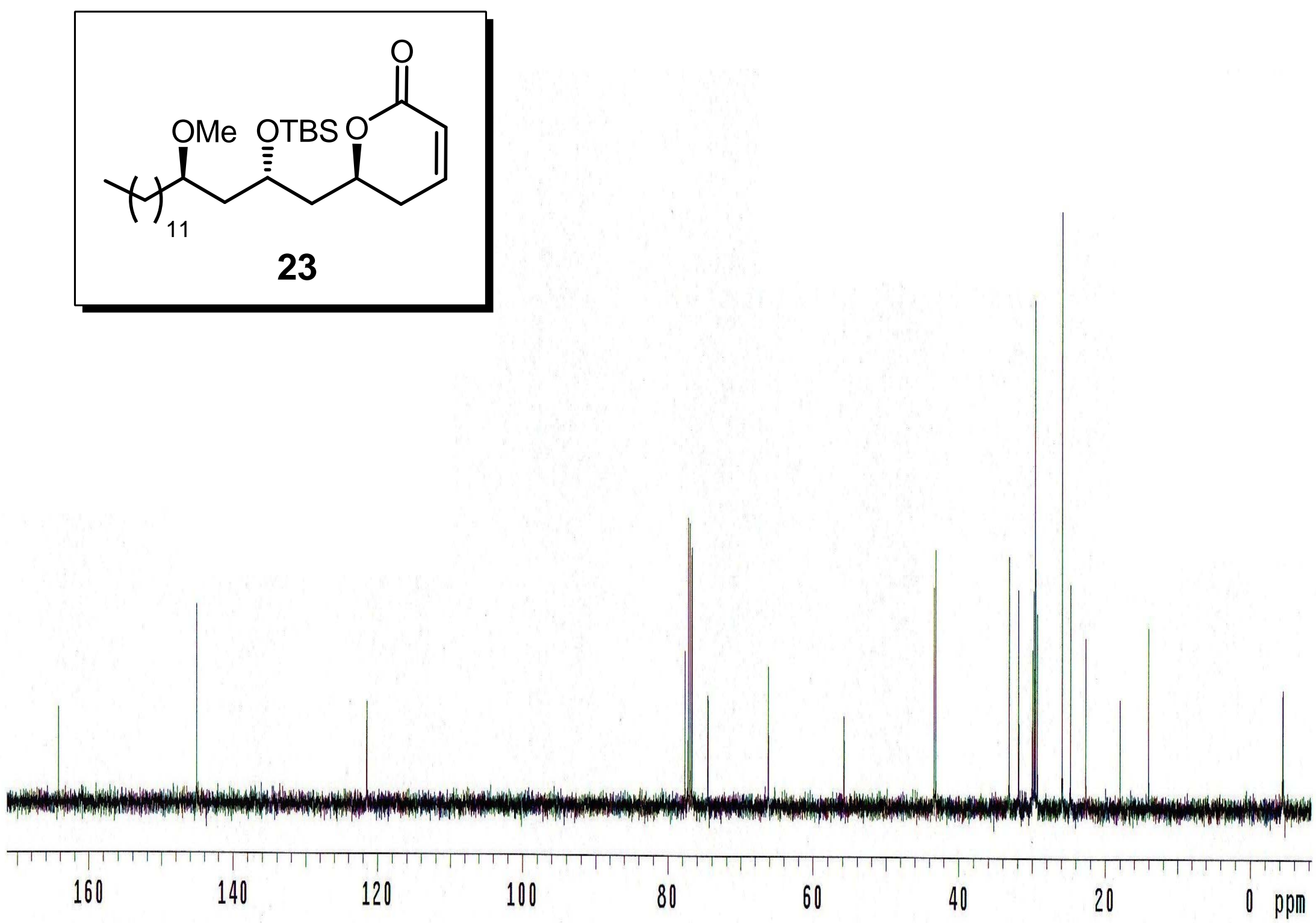

S-13 

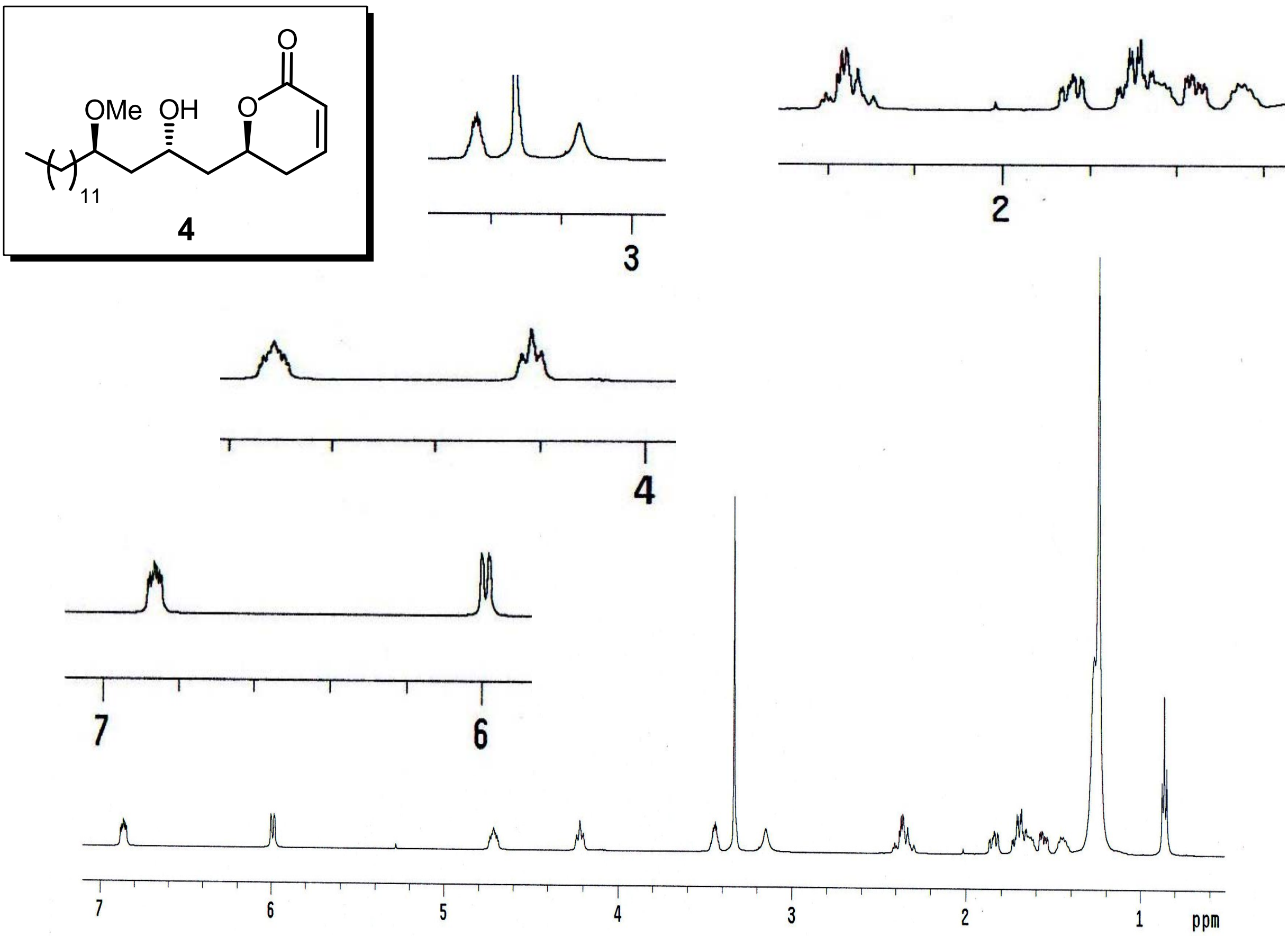

S-14 

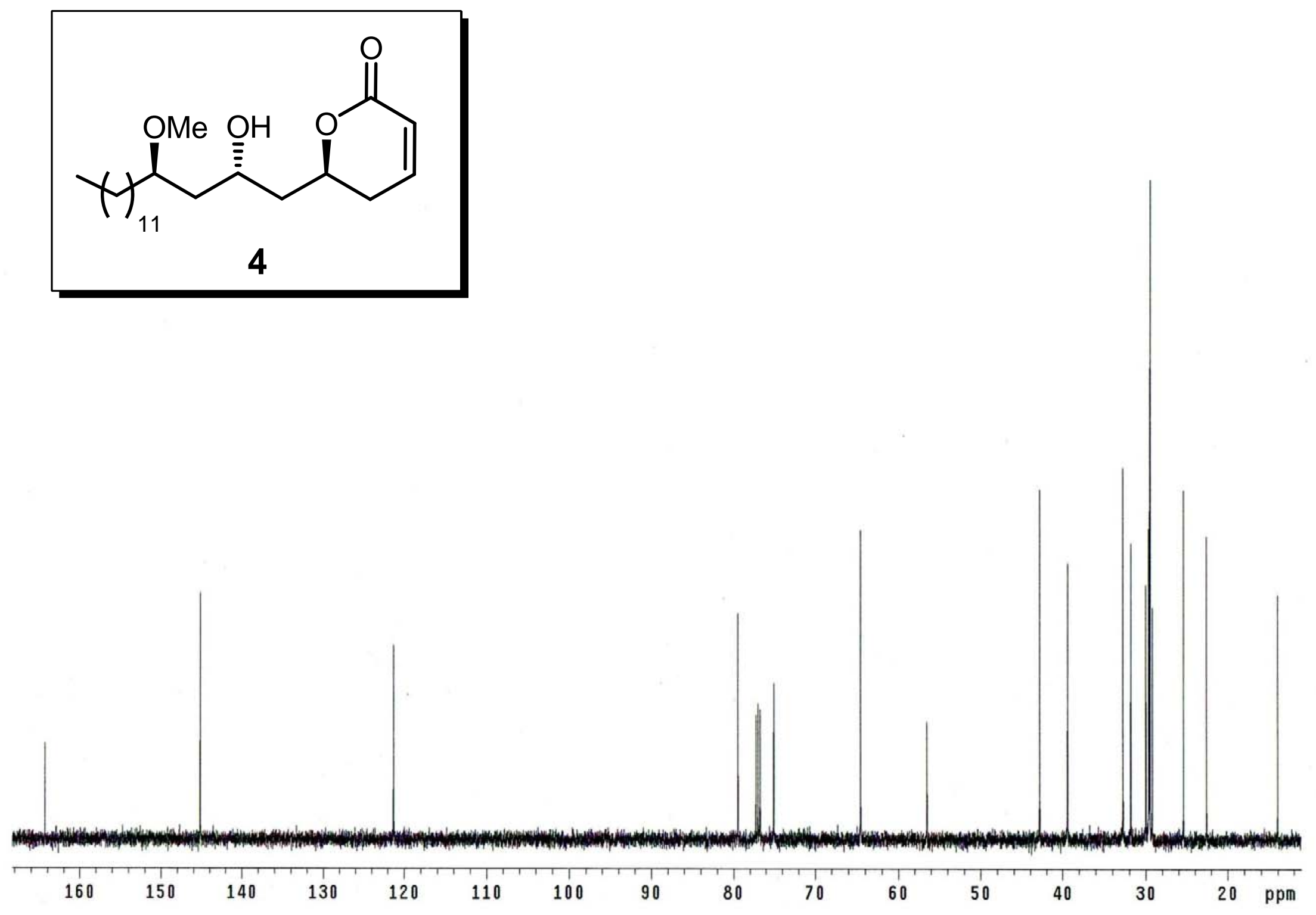

S-15 


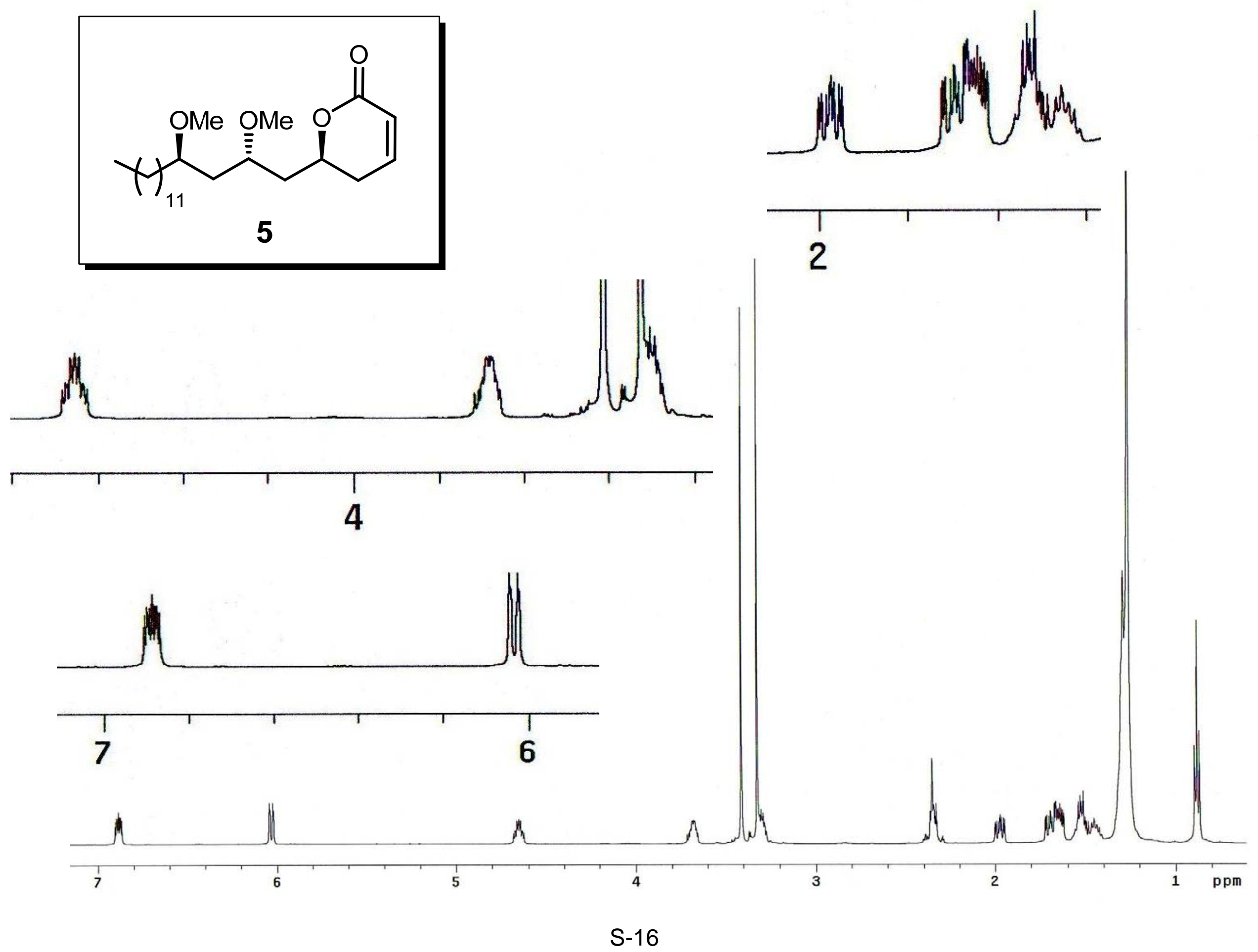






S-17 


\section{Synthesis and biological evaluation of pironetin analogues with enhanced lipophilicity}

Miguel Carda, $^{\dagger}$ Juan Murga, ${ }^{\dagger}$ Eva Falomir, ${ }^{\dagger}$ Santiago Díaz-Oltra, ${ }^{\dagger}$ Jorge García-Pla, ${ }^{\dagger}$ Julián Paños, ${ }^{\dagger}$ Chiara Trigili, ${ }^{\ddagger}$ J. Fernando Díaz, ${ }^{\ddagger}$ Isabel Barasoain ${ }^{\ddagger}$ and J. Alberto Marco ${ }^{\S}$

$+$

${ }^{\dagger}$ Depart. de Q. Inorgánica y Orgánica, Univ. Jaume I, 12080 Castellón, Spain; ${ }^{\S}$ CIB, CSIC, 28040 Madrid, Spain; and ${ }^{\ddagger}$ Depart. de Q. Orgánica, Univ. de Valencia, 46100 Burjassot, Valencia, Spain

\section{Supporting Information}

Contents:

S-2/S-13: $\quad N M R$ spectra of new intermediate and final compounds 


\section{NMR spectra of intermediate and final compounds}
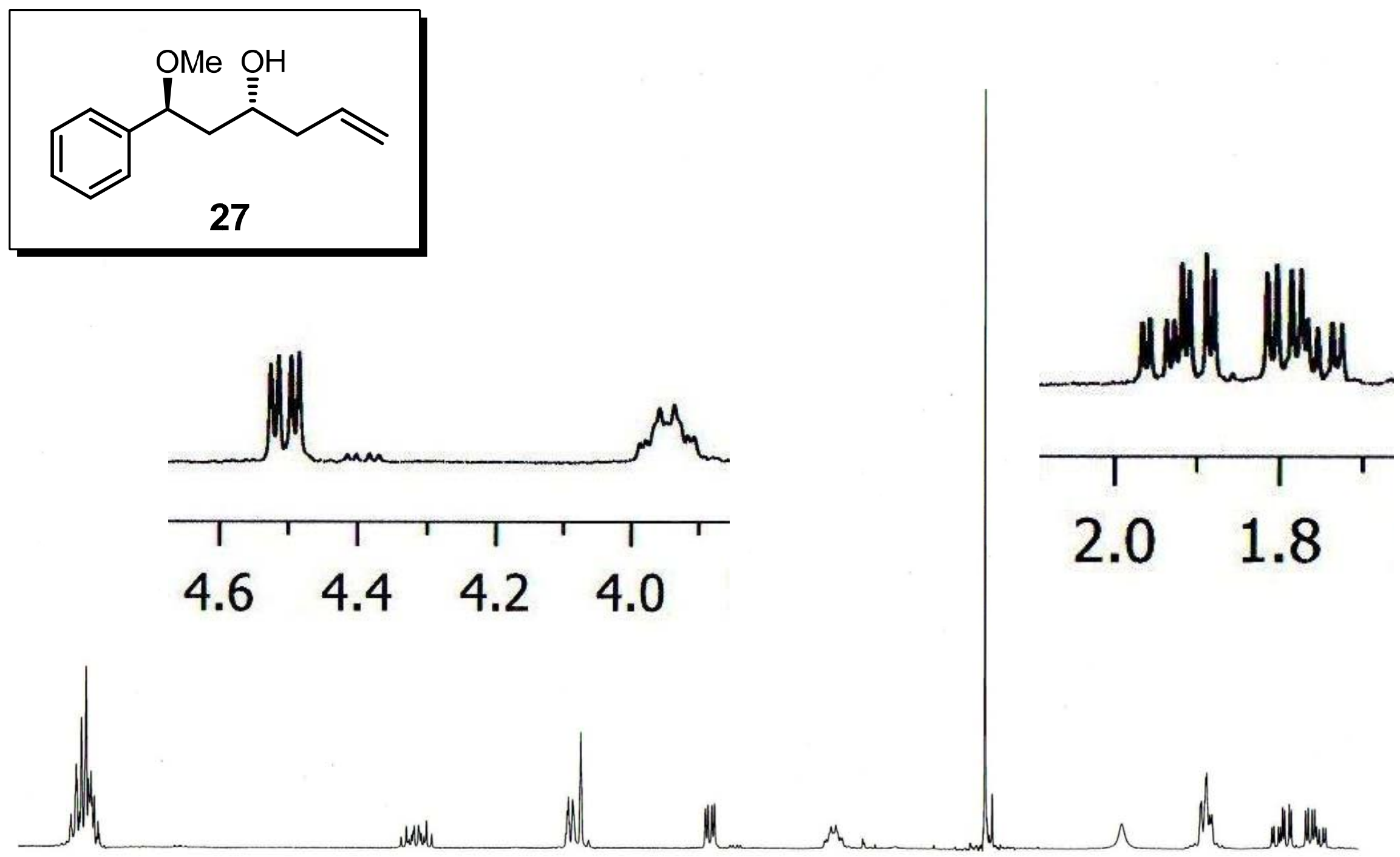

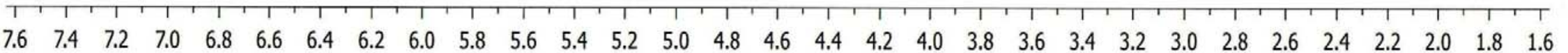

S-2 

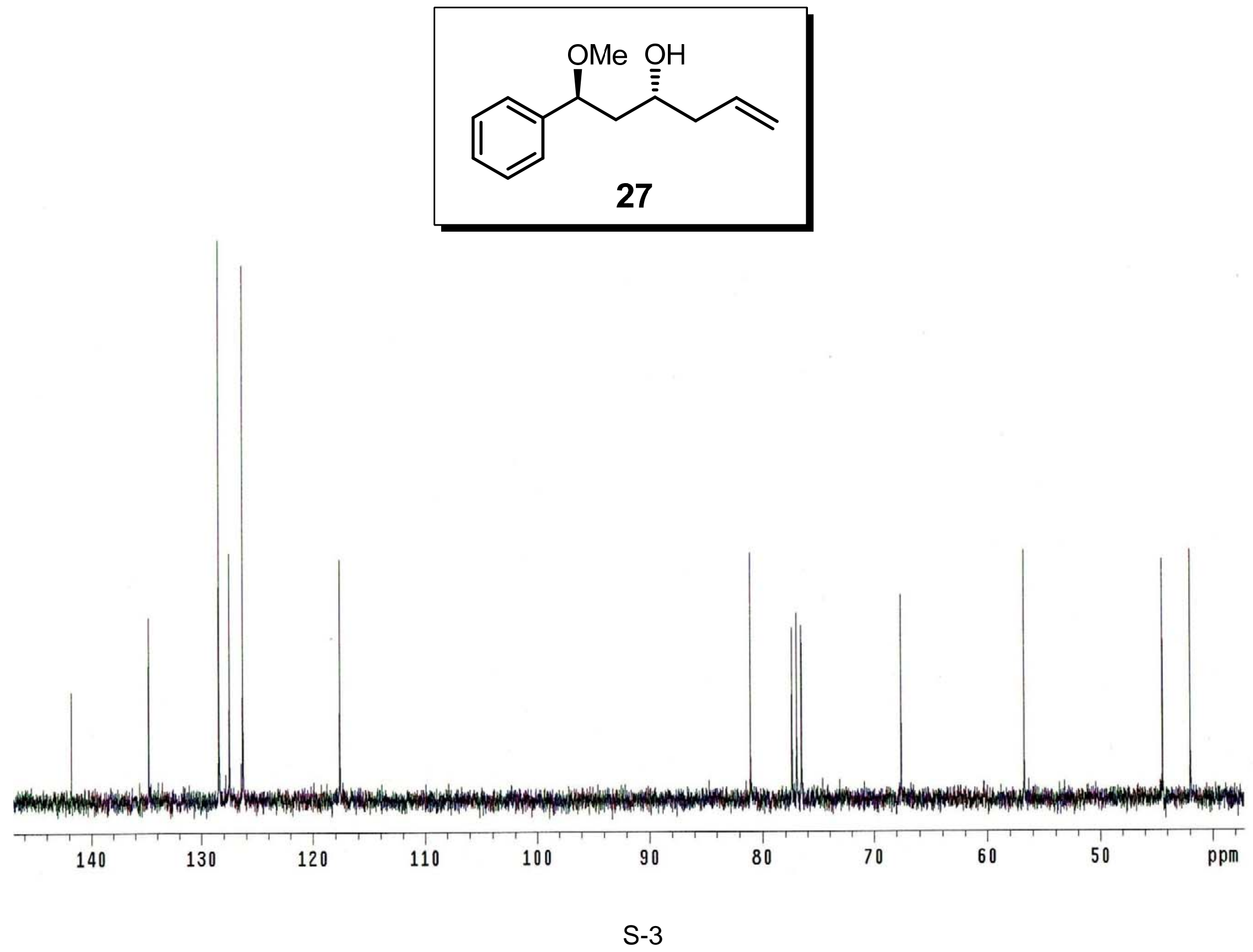


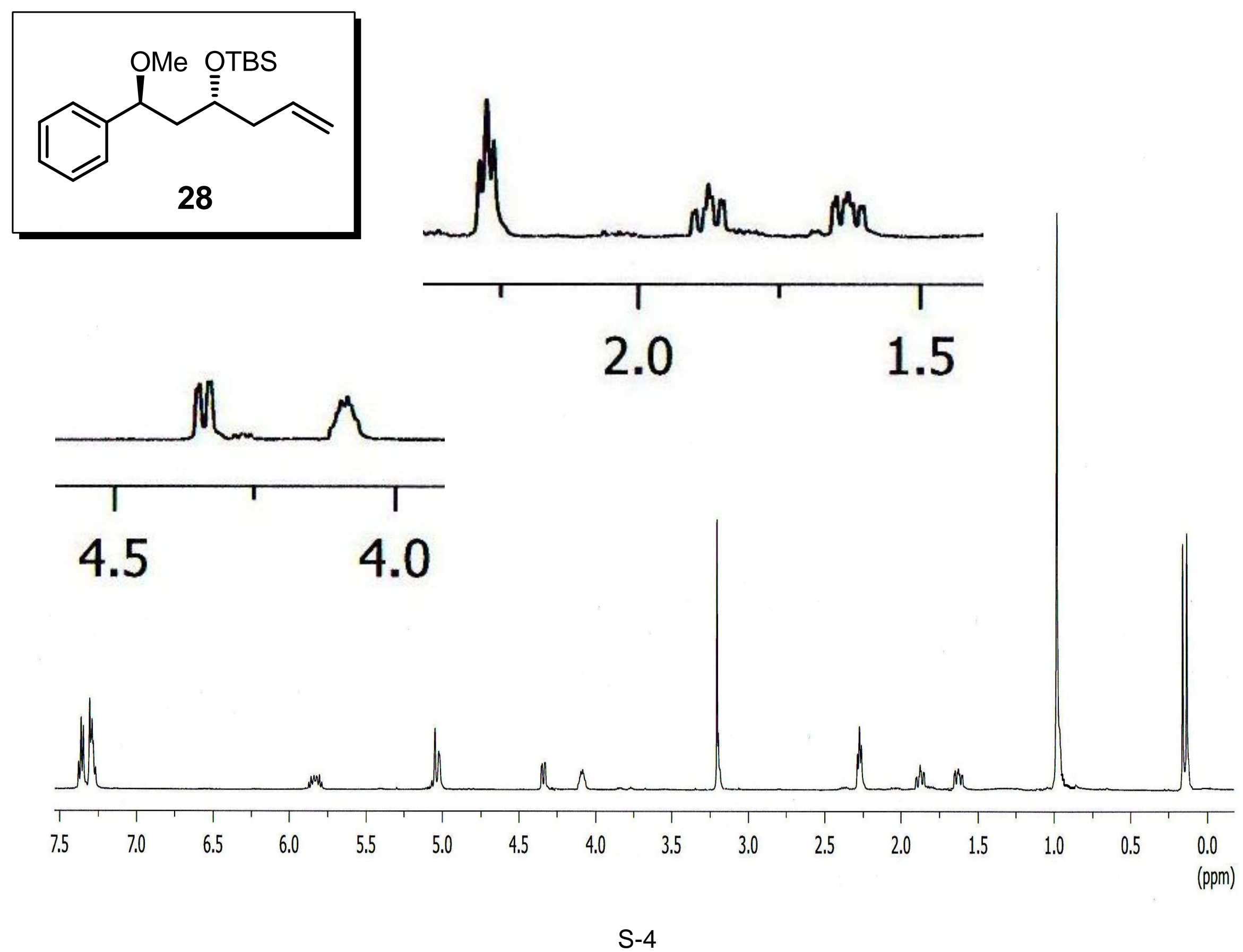



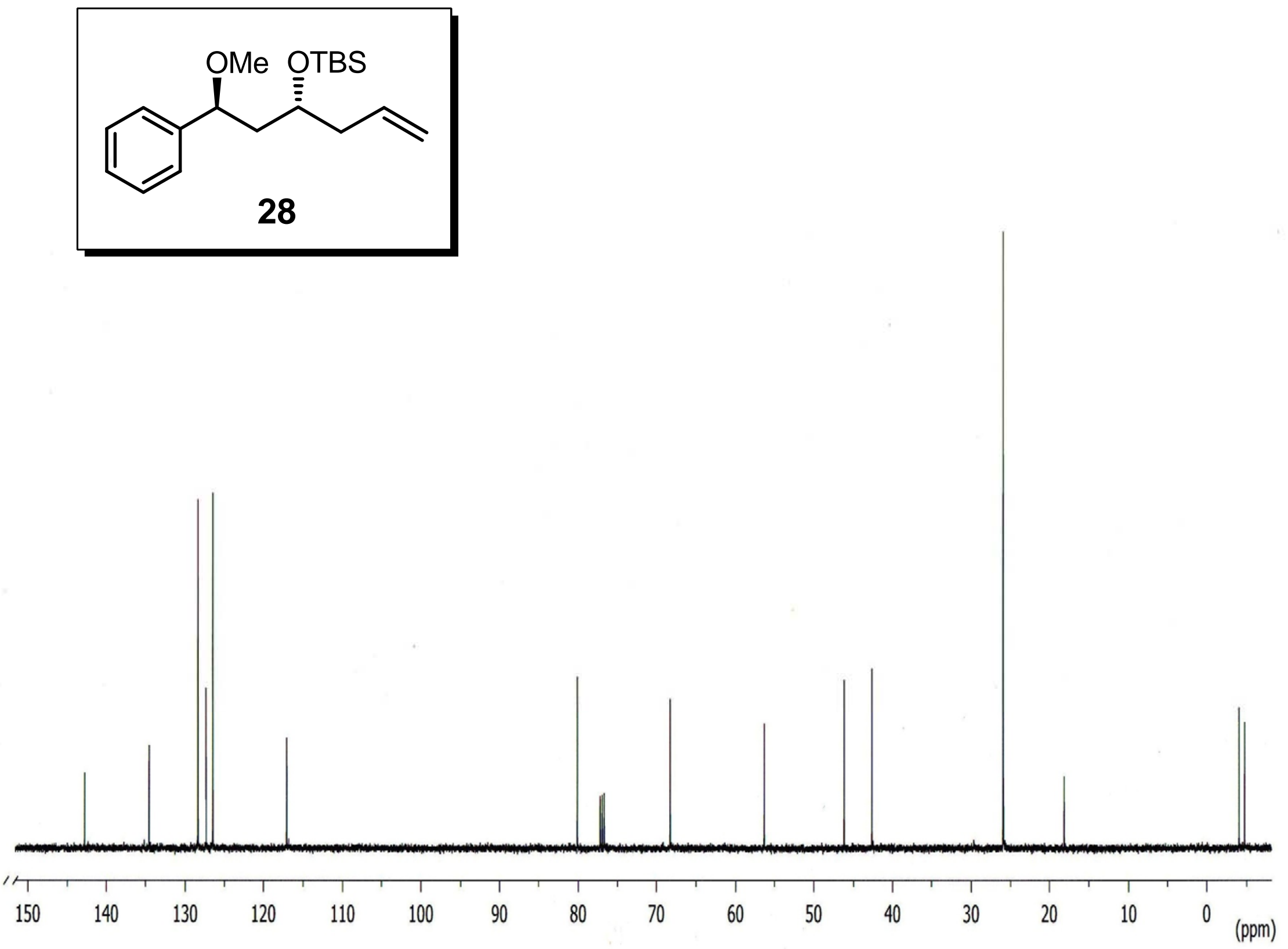


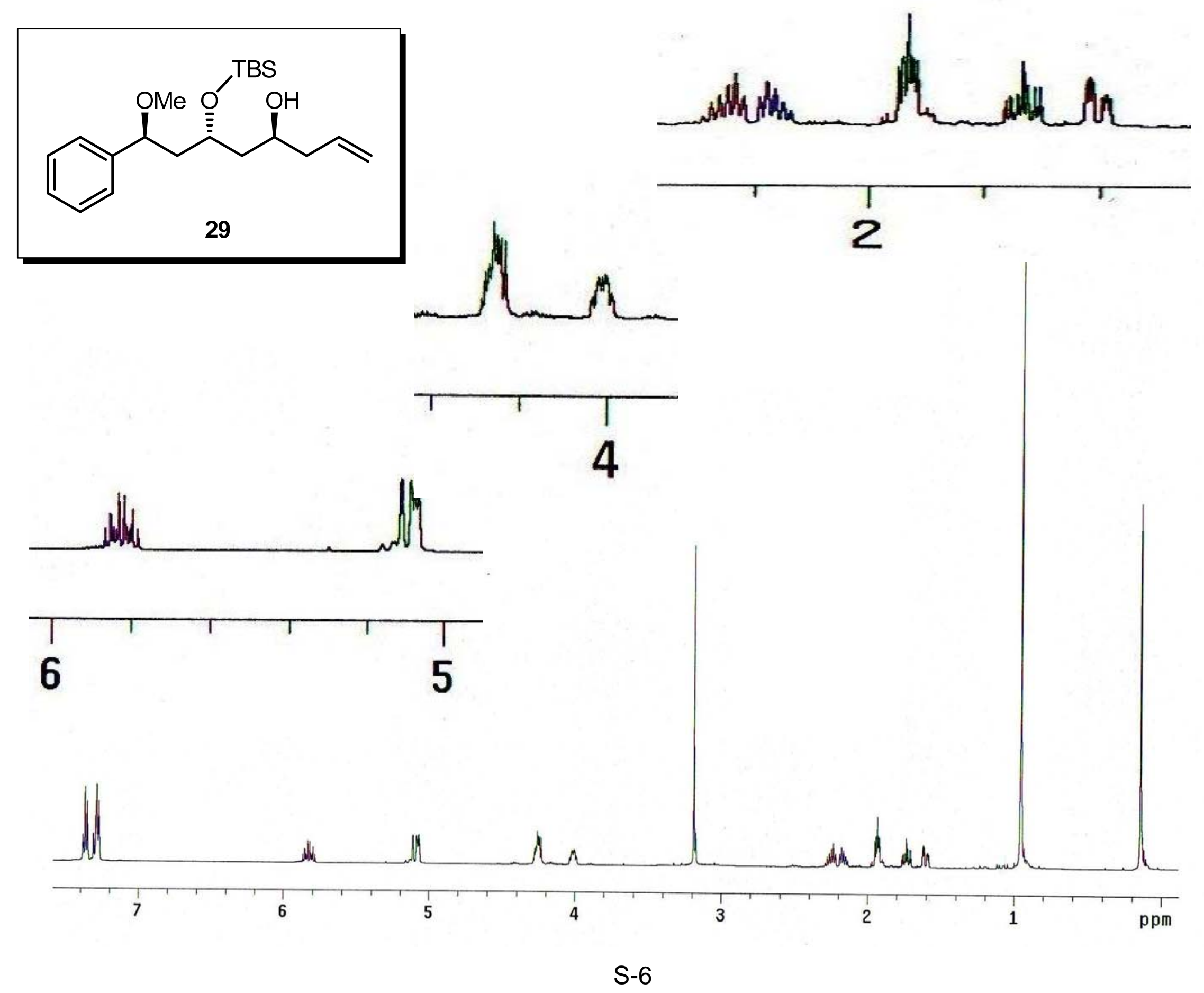



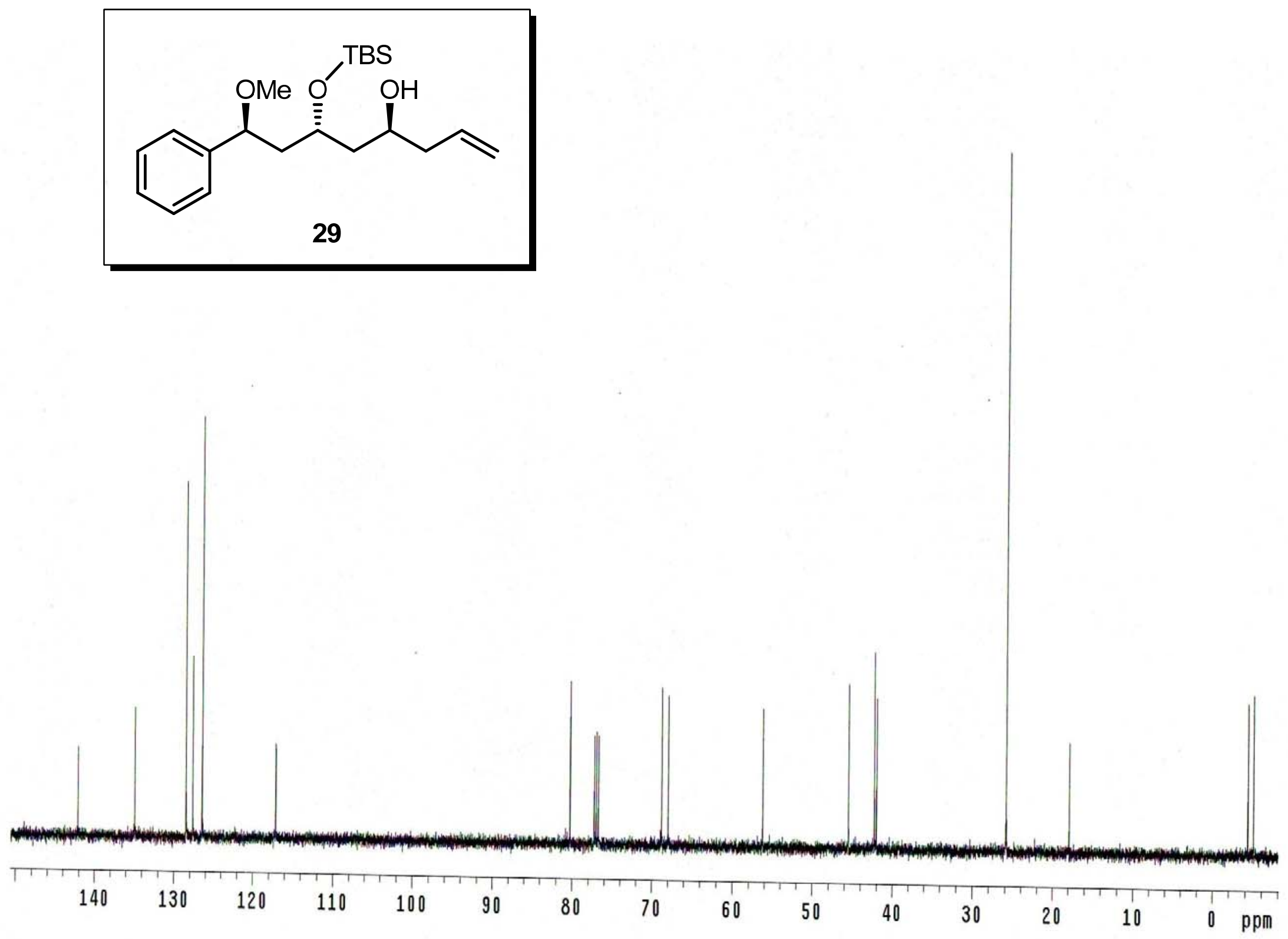


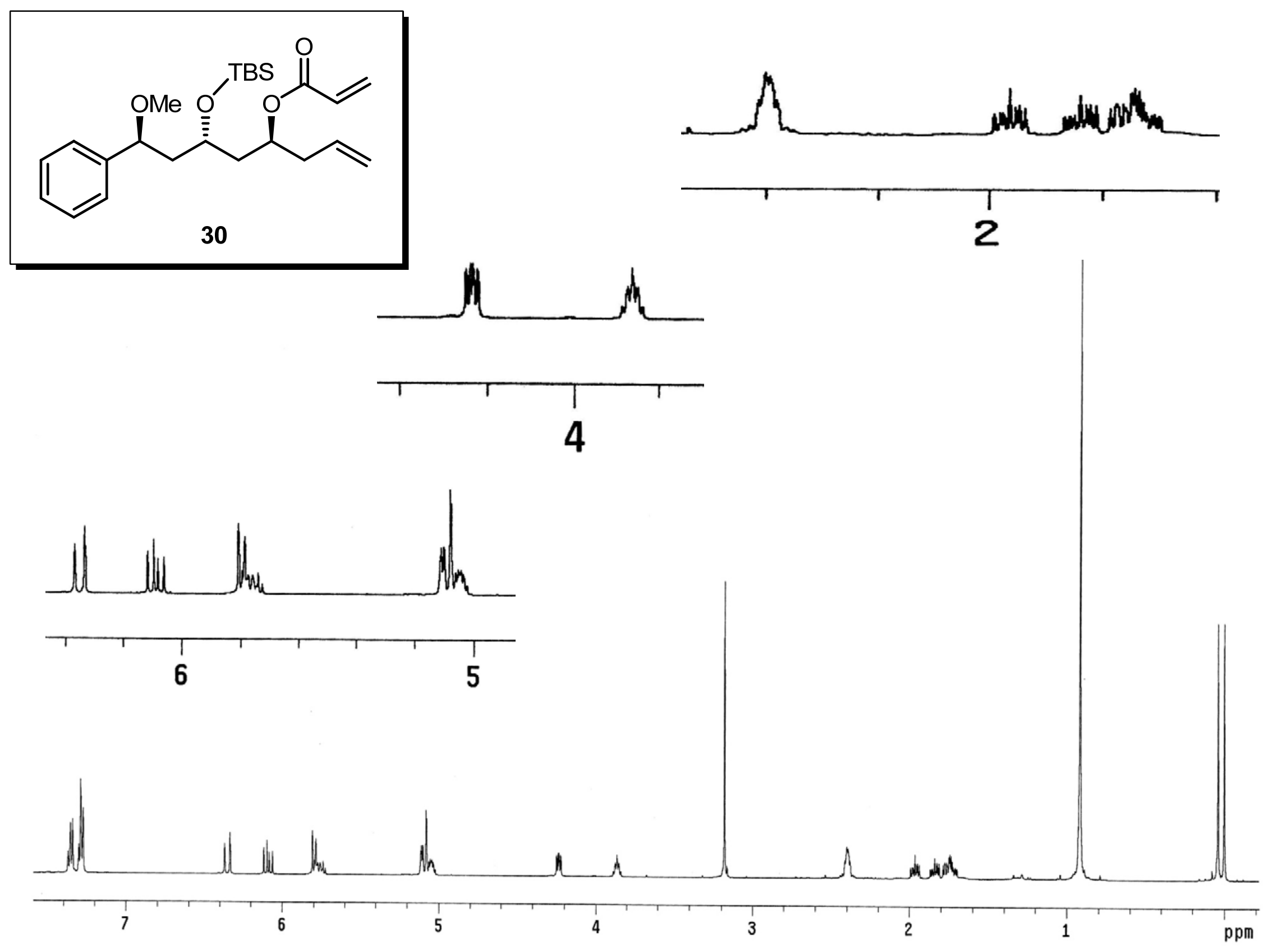

S-8 

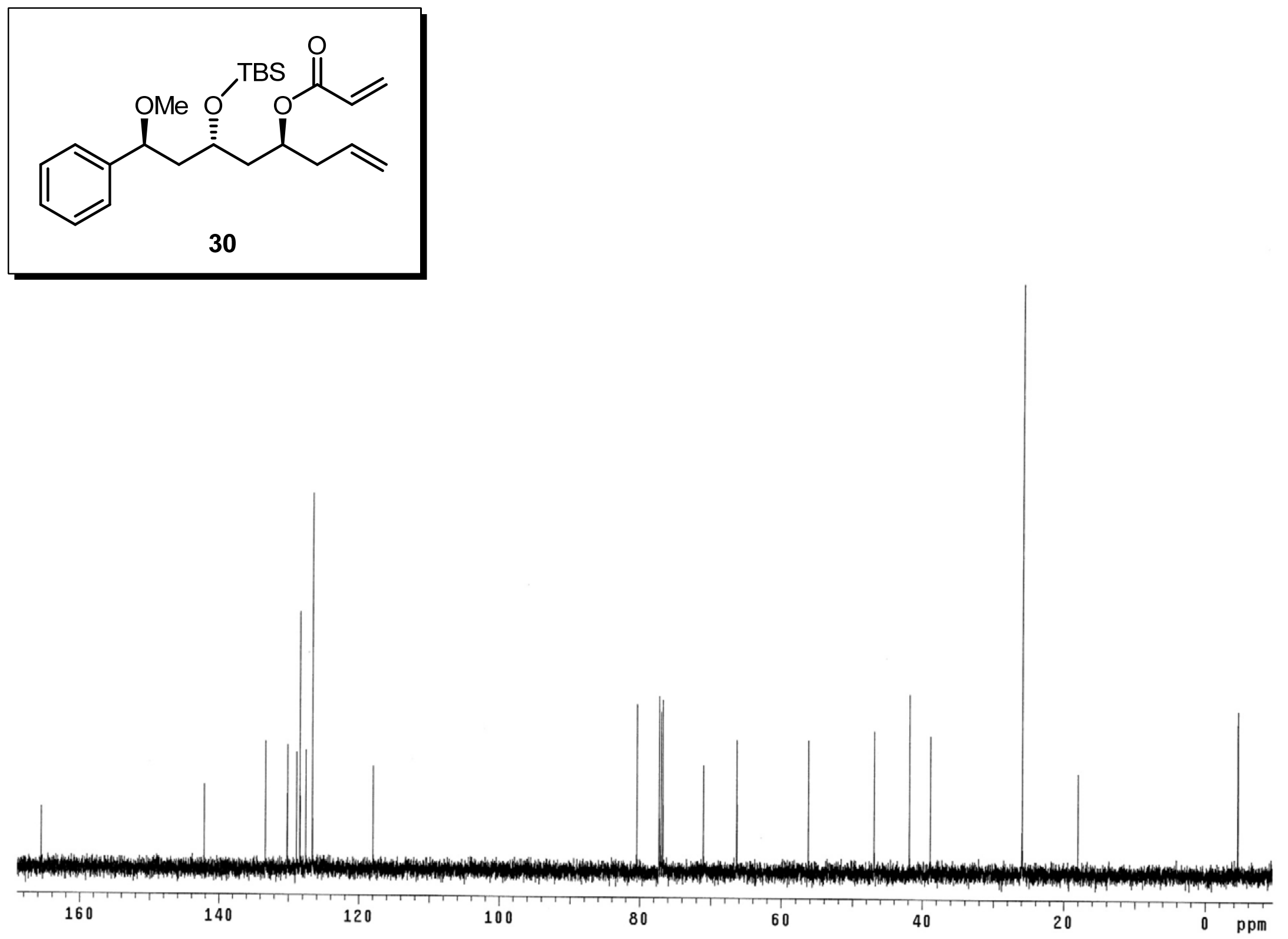

S-9 


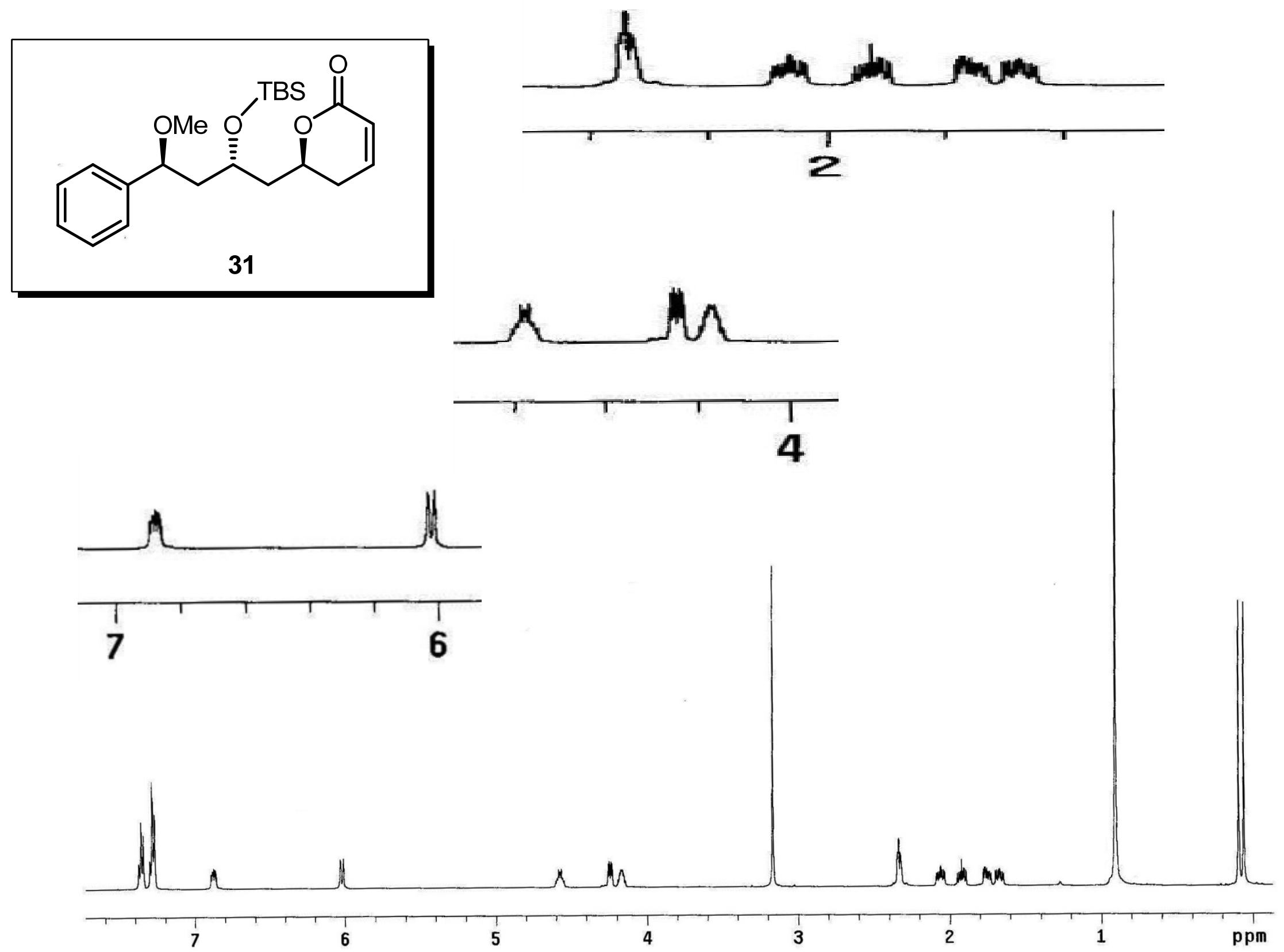

S-10 

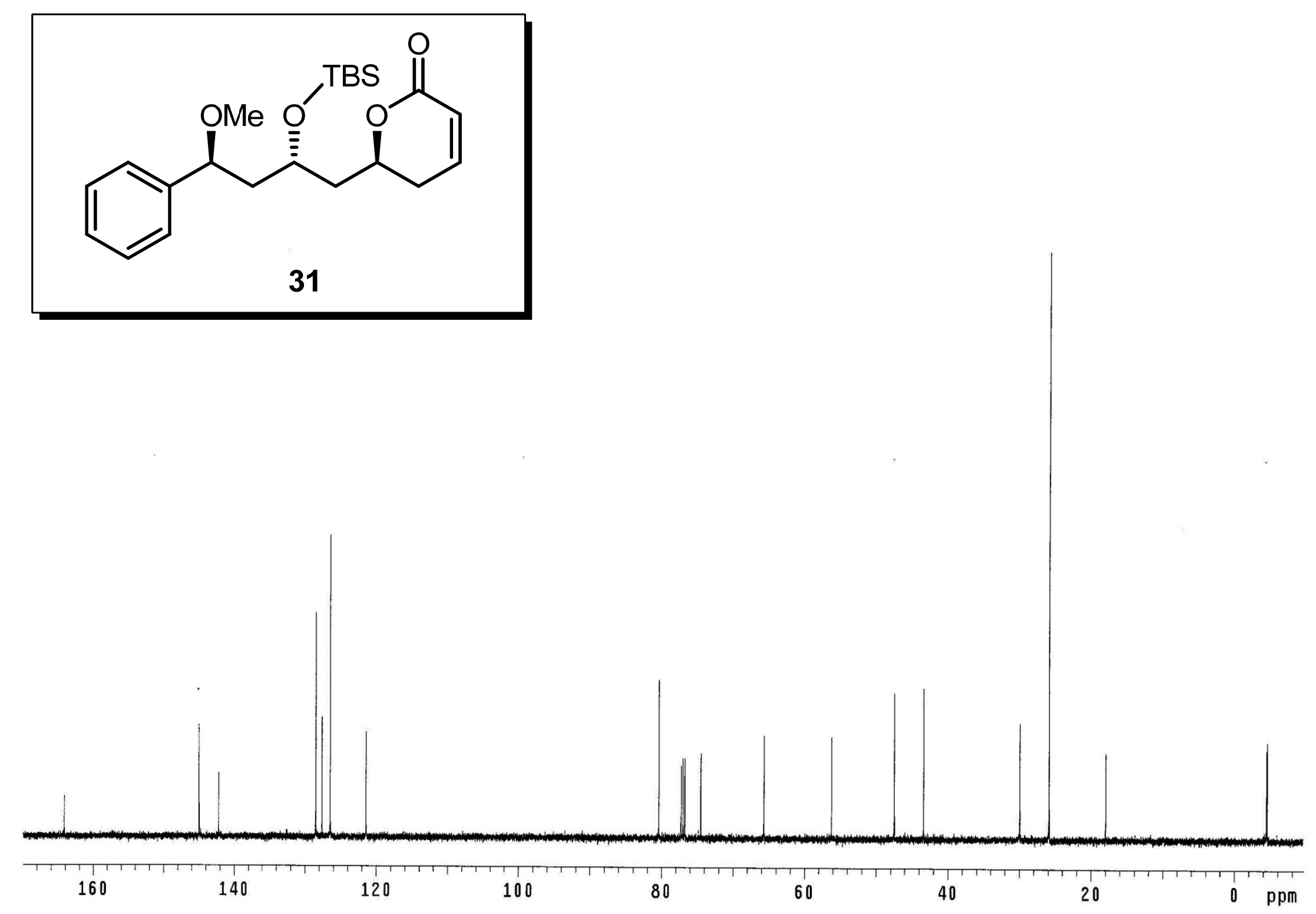

S-11 

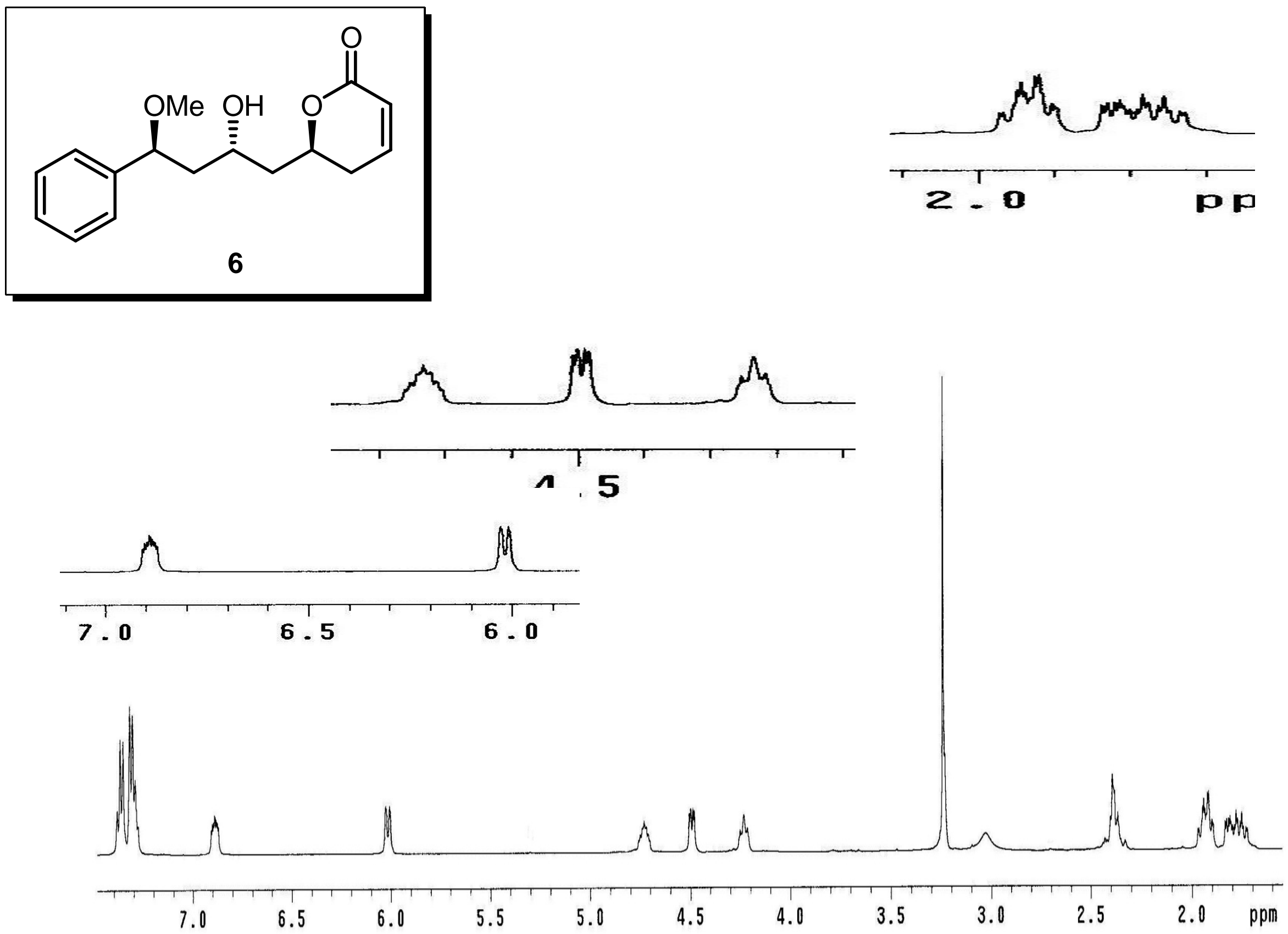

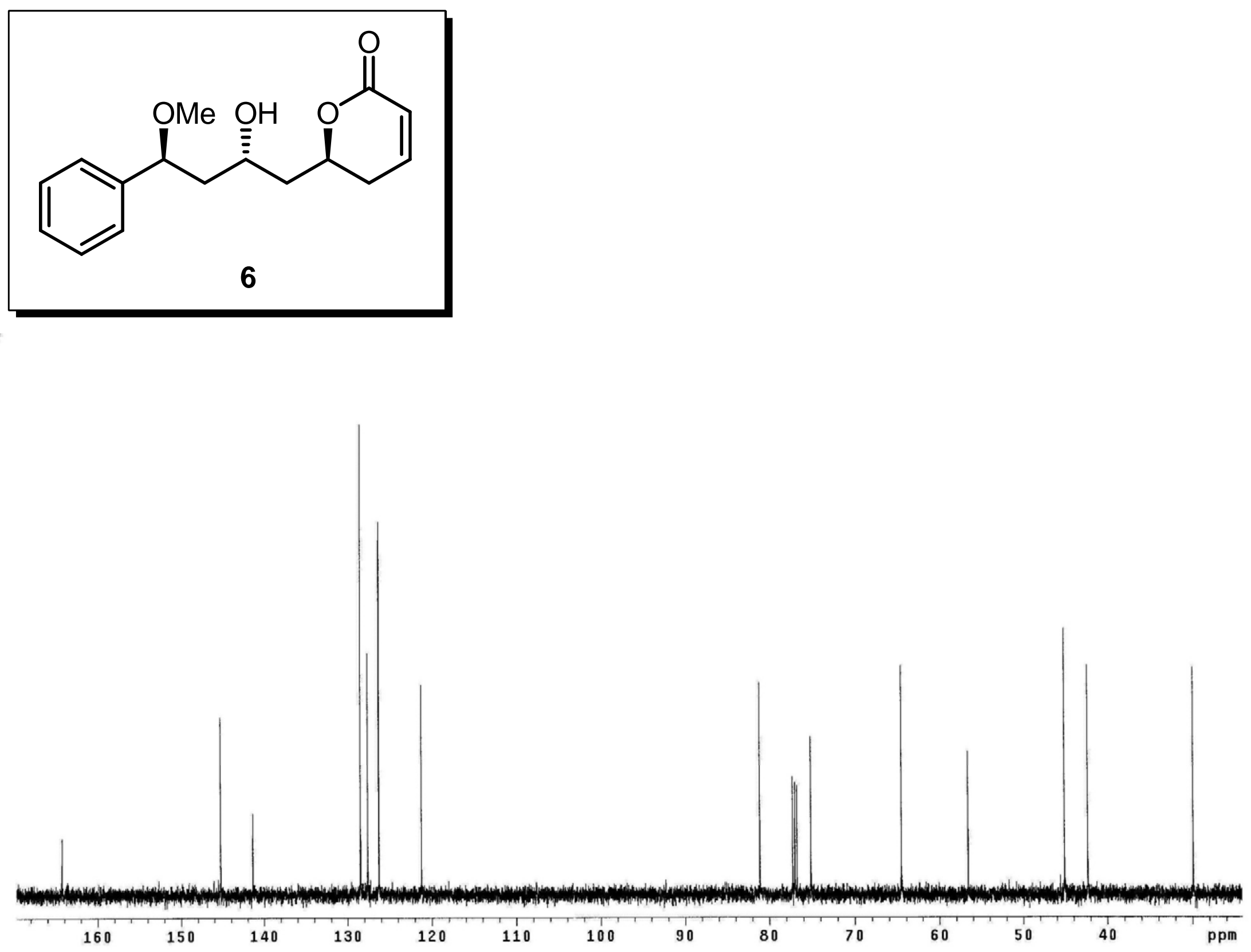

S-13 